IZA DP No. 5499

Labor Supply and Consumption Smoothing When Income Shocks Are Non-Insurable

Alexander M. Danzer

February 2011 


\title{
Labor Supply and Consumption Smoothing When Income Shocks Are Non-Insurable
}

\author{
Alexander M. Danzer \\ Royal Holloway College, University of London, \\ Ludwig-Maximilians-University Munich and IZA
}

\section{Discussion Paper No. 5499 \\ February 2011}

\author{
IZA \\ P.O. Box 7240 \\ 53072 Bonn \\ Germany \\ Phone: +49-228-3894-0 \\ Fax: +49-228-3894-180 \\ E-mail: iza@iza.org
}

Any opinions expressed here are those of the author(s) and not those of IZA. Research published in this series may include views on policy, but the institute itself takes no institutional policy positions.

The Institute for the Study of Labor (IZA) in Bonn is a local and virtual international research center and a place of communication between science, politics and business. IZA is an independent nonprofit organization supported by Deutsche Post Foundation. The center is associated with the University of Bonn and offers a stimulating research environment through its international network, workshops and conferences, data service, project support, research visits and doctoral program. IZA engages in (i) original and internationally competitive research in all fields of labor economics, (ii) development of policy concepts, and (iii) dissemination of research results and concepts to the interested public.

IZA Discussion Papers often represent preliminary work and are circulated to encourage discussion. Citation of such a paper should account for its provisional character. A revised version may be available directly from the author. 
IZA Discussion Paper No. 5499

February 2011

\section{ABSTRACT}

\section{Labor Supply and Consumption Smoothing When Income Shocks Are Non-Insurable}

The paper investigates how employees use secondary employment to smooth out consumption shortfalls from non-anticipated wage shocks in their main employment. The identification strategy exploits surprising changes in firms' wage payment and repayment behavior in Ukraine. Based on unique nationally representative panel data, the econometric approach accounts for workers' unobserved heterogeneity and measurement error in the wage shock information. The estimated labor supply responses suggest that secondary activities are used as temporary coping strategies against wage shocks and that they closely follow the lifecycle of wage arrears. Households that engage in secondary employment can successfully smooth their consumption. The results are robust to several alternative hypotheses concerning the observed labor supply pattern.

JEL Classification: J22, J33, P36, O17

Keywords: dual job holding, wage shock, consumption smoothing, subsidiary farming, reaction time to shocks

Corresponding author:

Alexander M. Danzer

Department of Economics

Ludwig-Maximilians-University Munich

Geschwister-Scholl-Platz 1

80539 München

Germany

E-mail: alexander.danzer@Irz.uni-muenchen.de 


\section{Introduction}

How do workers respond to non-anticipated transitory wage shocks in their main employment in a setting of imperfect markets, credit constraints and missing social security? Particularly, do they re-allocate working time between the main job and additional jobs? The goal of this research is to understand whether employees and their households are able to smooth out consumption against negative wage shocks in the main job by adapting their portfolio of activities. This is especially relevant if workers are unable to switch employers at low costs, for instance because wage non-payment exerts a bonding effect towards the current employer or because wage shocks are regionally concentrated.

The underlying theoretical framework of the paper is given by a simple dual job holding model with random wage shocks in the main job, so that additional jobs can be taken up in order to smooth out consumption shortfalls. The empirical analysis includes crosssectional and panel estimations based on a unique nationally representative data set from Ukraine for the early 2000s. This case study setting is interesting as shortfalls in wage payments were quite common (over 10\% of the workforce each year) and as unusually rich data on wage shocks are available. Coping activities were widely available so that employees can either enter a second position as dependently employed worker or use smallholder farming activities.

The paper addresses several potential empirical problems in the estimation of a multiple job holding model. For instance, it deals with omitted variable bias by accounting for unobserved heterogeneity through fixed effects estimation. The analysis also addresses measurement error in the reported wage shocks by applying an instrumental variable (IV) method that exploits the fact that firms' pay practices were regionally highly concentrated.

The estimated labor supply responses to wage shocks indicate a re-allocation of working hours from main to second jobs-with important differences between activities. Exogenous variation in firms' wage repayment is used to show the robustness of the identified effects. As workers resemble participants of a lottery and cannot determine the arrival of wage repayment, it is possible to test the motivation for holding second jobs and to study the consumption smoothing behavior over the entire duration of the wage shock cycle. Further support stems from the fact that none of the presented alternative hypotheses can convincingly rival the consumption smoothing motive of second job holdings. This also implies that there is no evidence for anticipatory behavior in the sense that workers might respond to shocks ex-ante. In line with the estimated individual labor supply responses, 
households cannot ex-ante insure their consumption against wage shocks but manage to smooth out temporary shortfalls with the help of secondary activities.

The contributions of this paper are the following: This is the first empirical study to analyze second jobs as a mode of consumption smoothing in the presence of main job wage shocks. Combining three previously unrelated strands of literature on wage shocks, second job holdings and consumption smoothing helps to gain new insights into how individuals and households manage to cope with income shocks. Different from much of the previous literature this paper exploits direct evidence on exogenous wage shocks. This unique variation in wage levels allows to explicitly link firms' wage policies to individual shock responses over the entire duration of the earnings loss. Wage shocks have adverse effects on workers at the time they occur, but this paper additionally analyzes the effect of the termination of the shock-by using unique information on exogenous repayments. The analysis of both onset and offset of wage shocks lends substantial robustness to the estimates. Finally, this study extends the application of a dual job labor supply model to an emerging country context. The research is based on the supposition that individuals are myopic and credit constrained which seems quite realistic for many lower and middle income countries.

There are two main aspects of this research which are of particular policy relevance: First, the analysis of wage shocks illustrates how firms' payment policies affect labor supply. Legal institutions that are too weak to enforce wage claims drive individuals into coping mechanisms which might potentially imply an inefficient allocation of resources. This is especially so when regional clustering of bad payment practices prevents regional labor markets from functioning. Second, this paper investigates the question whether unanticipated wage shocks can be smoothed out by individuals and households in imperfect capital markets, i.e. when wage shocks cannot be insured. The impact of wage shocks is especially immediate in a setting where household savings have been depleted and hence cannot be used to buffer the shortfall and where the state does not provide any social security minimum. ${ }^{1}$ Low mobility across jobs, sectors and regions prompts 'on-the-job-responses'. Thus, the following research addresses the ability of households to engage in self-help as well as the subsequent welfare implications. ${ }^{2}$

\footnotetext{
${ }^{1}$ Suffering from wage arrears does not entitle to the receipt of any state benefits. For the years prior to the Russian financial crisis 1998/1999, Guariglia and Kim (2003) found evidence for some precautionary saving behaviour in Russia.

${ }^{2}$ As will be briefly discussed in the conclusion, the shift from main to second jobs may also change the role of the informal sector, which might be larger for second job holdings (cp. Guariglia and Kim, 2006).
} 
The remainder of the paper is structured as follows: Section 2 reviews relevant economic concepts of the labor allocation decision under uncertainty, multiple job holdings and consumption smoothing. It also provides background information on the nature of wage shocks and coping activities in Ukraine in the 2000s. Section 3 introduces the data sets. Section 4 presents and discusses the econometric approach. The results concerning the individual labor supply responses to wage shocks and the consumption smoothing abilities of households are reported in Section 5. Section 6 discusses potential alternative hypotheses and presents the results of several robustness checks. The final section concludes with policy implications.

\section{Background}

\subsection{Theoretical Background}

One of the fundamental questions in labor economics is how individuals adapt their labor supply in response to wage or income changes. Research on transitory wage shocks has received limited attention for substantial time, as permanent income or consumption insurance models pay disproportional attention to permanent shocks. Consequently, the modern intertemporal model of labor supply has largely ignored transitory wage shocks because it expects them to play only an insignificant role in the life cycle labor supply decision. ${ }^{3}$ In recent years, however, the interest in wage uncertainty and transitory wage shocks surged as the assumptions of the inter-temporal labor supply model seem too restrictive. Mainly, the suppositions of perfect foresight and the absence of credit constraints are inadequate for many countries, and in particular in countries with incomplete markets and ongoing structural change, like most developing and emerging countries. The latter setting prompts the use of the myopic consumption model, in which individuals react to transitory shocks as they would react to permanent ones (Jappelli and Pistaferri, 2006). Beside theoretical reasons in favor of the study of transitory wage shocks, a higher econometric sensitivity to distinguish anticipated from non-anticipated wage shocks has promoted research on unanticipated transitory wage shocks — a field that had been ignored until recently (Pistaferri, 2003).

Three strands of literature are central to investigating the effect of wage shocks in the main job on consumption smoothing through coping activities. In a standard labor supply

\footnotetext{
${ }^{3}$ When the marginal utility of wealth is constant over time.
} 
model with only one job, the effect of wage uncertainty on labor supply is theoretically ambiguous. Block and Heineke showed that higher wage uncertainty leads to increased working effort if the substitution effect towards leisure is dominated by the income effect in the Hicks-Slutsky equation (Block and Heineke, 1973). However, this literature does not allow for the possibility of second jobs. Around the same time, multiple job holding models emerged with a particular focus on the labor supply behavior of individuals who face working hours constraints in the main job. In their model of second job holdings, Shishko and Rostker (1976) formally derived cross-wage labor responses and showed that individuals who are hours constrained will increase second job labor supply with decreasing main job wage if leisure is a normal good. An increase in non-labor income leads unambiguously to a decrease in second job holdings through the income effect. Other authors describe alternative motives to hold a second job-like the portfolio combination of stable and secure with casual prestigious employment-without explicitly addressing the role of consumption smoothing (Paxson and Sicherman, 1996; Smith Conway and Kimmel, 1998). The third strand of literature focuses on consumption smoothing in general, and on the question how people reduce income risk specifically. Different from the truly inter-temporal labor supply model which expects transitory wage shocks to have no effect on labor supply, today's perception is that insurance is incomplete, especially for unexpected or low-frequency shocks. For both, developing and developed countries, economists have presented evidence that shocks are not perfectly insurable and that households engage in specific consumption smoothing activities (Cochrane, 1991; Townsend, 1994; Attanasio and Székely, 2004). ${ }^{4}$ This paper combines all three strands of literature in order to pay attention to the potential consumption smoothing motive of secondary jobs, specifically against main job wage shocks. Myopic and creditconstrained individuals cope with income shortfalls by reallocating effort between main and second jobs. The novel aspect of this paper is that it focuses on within-person labor supply responses which crucially depend on the availability of outside insurance options (Low, Meghir and Pistaferri, 2010). In this respect this paper stands in contrast to the added worker

\footnotetext{
${ }^{4}$ For countries with at least basic social security systems, one can expect that social protection indeed smoothes out labor market shocks_-and simultaneously at least partly crowds out coping mechanisms (Cullen and Gruber, 2000). However, even under these conditions, increasing inequality over the life cycle is hard to explain when precluding the importance of uninsurable idiosyncratic risks (Storesletten, Telmer and Yaron, 2001).
} 
literature, which investigates labor supply responses of married women to their husband's unemployment (Lundberg, 1985). ${ }^{5}$

The following analysis is based on a simple static model of labor supply. Individuals are assumed to maximize utility $U(c, l)$ which for simplicity only contains two arguments, consumption $c$ and leisure $l$. There are two main reasons for choosing a static model of labor supply: First, Ukraine, the country under consideration, is a lower middle income country in which individuals are severely credit constrained; ${ }^{6}$ thus a life cycle model which assumes away credit constraints would be inappropriate. Second, the wage shocks which individuals are facing in this setting (and which will be described in greater detail below) are unanticipated so that employees can be assumed to behave myopically.

Employed individuals allocate effort $h$ between two different jobs (subscript 1 indicating the main job and 2 indicating the optional secondary activities) subject to a total time (T) constraint $T=h_{1}+h_{2}+l$ with $h_{1}>0, h_{2} \geq 0$, the budget constraint $y=w_{1} h_{1}+w_{2} h_{2}$ $+A$, where $w$ indicates the wage rate for main or second job and $A$ is a measure of non-labor income, as well as to a non-hiring constraint $h_{1}+h_{2} \leq T$. In an environment of working hours constraints, Sishko and Rostker (1976) have shown that a decrease in the main job wage rate lets an individual shift effort towards the second job. It is straightforward to consider a similar problem in a setup with a stochastic wage shock $\gamma$ (as in Kurkalova and Jensen, 2000). Kurkalova and Jensen show that the behavioral responses are $\partial h_{2} / \gamma>0$ and $\partial h_{1} / \gamma<0$.

\subsection{Wage Arrears}

Ukraine offers an interesting setting to analyze labor supply responses to wage shocks under myopia and credit constraints: The high incidence of wage arrears in the country provides an interesting source of exogenous variation in wage payments. But while wage arrears were seen as a characteristic feature of post-Soviet labor markets in the mid-1990s, they gained prominence in several countries during the recent global financial crisis (ILO, 2009). Even before, wage arrears had become increasingly problematic in some developing and emerging countries, for instance, among migrant workers in China and the Middle East (UNDP, 2005) and in many enterprises in India. In industrialized countries, wage arrears are

\footnotetext{
${ }^{5}$ Consequently, one caveat of the analysis concerns the joint labor supply decision within households (Becker, 1965) which remains beyond the scope of this research. The labor force participation of women in Ukraine is quite high so that the scope for more spouses to enter the labor market is limited.

${ }^{6}$ According to the World Bank (2008), access to financial intermediation in Ukraine even lags behind countries like Angola, Burkina Faso, Côte d'Ivoire, El Salvador, Libya and Mongolia-to name just a few.
} 
of minor importance on the aggregate level and mostly appear temporarily when firms, e.g. start-ups, undergo financially difficult times; however, more structural wage arrears can be observed for the close-to-poverty part of the working population. In the UK, for instance, wage arrears were problematic as a consequence of enterprises failing to pay at least the legal minimum wage, especially before drastic fines and a short pay-back period were introduced in $2007 .^{7}$

Arrears were initially understood as a consequence of decline in demand during the recession or as a result of firms' illiquidity. ${ }^{8}$ However, this perspective was challenged when matched employer-employee data from Russia revealed that wage arrears were observable not only in poorly-performing but also in many well-performing firms and that worker turnovers remained relatively modest despite the substantial losses to individual incomes. From these findings, Earle and Sabirianova (2002) developed an institutional theory of wage arrears which understood wage non-payment as a function of managerial contract-violating behavior and poor contract enforcing institutions. ${ }^{9}$ In other words, poor managerial behavior and workers' inability to enforce wage claims through courts led to substantial levels of wage non-payment. ${ }^{10}$ Wage arrears were found to be sectorally and regionally highly correlated with little structure across groups of workers so that the tacit collusion in contract violation seriously restricted outside options for workers (Earle and Sabirianova, 2009). ${ }^{11}$ Hence, the

\footnotetext{
${ }^{7}$ According to HMRC inquiries, 25,000 low-pay employees were affected by wage arrears in the UK in 2006 (BBC, 2007).

${ }^{8}$ The neoclassical view of this phenomenon regarded wage arrears as a flexible tool to cushion the hardship of restructuring overstaffed state enterprises (Lehmann, Wadsworth and Acquisti, 1999; Desai and Idson, 2000).

${ }^{9}$ The above cited study on China clearly depicts discrimination between home and migrant workers in China as main reason for wage arrears. Also in the UK, non-payment of legal minimum wages can be expected to reflect managerial behaviour rather than illiquidity of firms.

${ }^{10}$ In most cases, workers did not file lawsuits, as courts were not assertive and their decisions had huge delays (cp. Earle, Spicer and Sabirianova, 2004). Court decisions in favor of workers were regularly ignored up until mid 2005, when a Ukrainian teacher won her case at the European Court of Human Rights (CFTUU, 2008). The Accounting Chamber of Ukraine states that "the systematic failings and infringements [...] identified [in wage non-payment] suggest an inadequate level of organization [...] and a lack of control" in many administrative bodies of Ukraine (UN CESCR, 2007: 14).

${ }^{11}$ As a legacy from the Soviet Union, the existence of one-factory-towns and regionally concentrated economic sectors have clearly contributed to a geographic clustering of these shocks. Earle and Sabirianova (2002) argue that poor outside options in local labor markets might set free a self-enforcing spiral of wage arrears, as local entrepreneurs find it increasingly attractive to hold back wages. What is less well established is whether there was differential treatment of employees within firms and whether this might have induced worker selection. While Earle and Sabirianova (2002) find that leading positions in firms suffered less from wage arrears, Gerry, Kim and Li (2004) claim that firm managers allocated wage arrears according to equity principles, implying that the least earning workers were spared. To the opposite, Lehmann et al. (1999) find that regional and firm characteristics are strong predictors for wage arrears, while individual characteristics play a negligible role. All three papers use data from Russia and the only evidence on Ukraine from the 1990s reveals that personal characteristics play no significant role in the determination of wage arrears, while economic sector and regional location of the employee explain the incidence of arrears quite accurately (Boyarchuk, Maliar and Maliar, 2005).
} 
local concentration of wage arrears diminished incentives to completely change employers. This added to a generally low mobility of workers across jobs and sectors in transition economies (Boeri and Flinn, 1999). When insurance and outside job options are missing, leaving the region might be regarded as an alternative strategy in response to wage nonpayment. Yet, mobility rates in transition countries were generally low and even declining despite a substantial rise in regional disparities (Fidrmuc, 2004). ${ }^{12}$ These specific features of the regional labor markets make secondary activities a plausible alternative for risk diversification.

In Ukraine, the incidence of wage arrears peaked at the end of the 1990s and declined thereafter. Survey evidence for 1996 and 1999 shows that two third of employees suffered from wage arrears in both years (Boyarchuk, Maliar and Maliar, 2005). According to the International Labor Organisation, the average Ukrainian employee was owed the amount of six monthly wage payments in the 1990s (ILO, 1996). Figure 1 illustrates that wage shocks in the form of aggregate wage arrears were very high in the late 1990s. Starting at this extreme incidence of wage non-payment, many Ukrainians were paid back outstanding wages during the period of strong economic growth in the early 2000s. Still, the sum of wages owed by current employers exceeded 1 percent of annual GDP in the years 2003 and $2004 .{ }^{13}$

Generally, there is no evidence of systematic sorting of workers across firms as a consequence of wage arrears (Earle and Sabirianova, 2002).

${ }^{12}$ Reasons which may explain the low labor mobility and thus contribute to the persistence of shocks in certain regions include liquidity constraints, high search costs, administrative barriers and underdeveloped housing markets (Andrienko and Guriev, 2004).

${ }_{13}$ As these aggregate figures exclude wage arrears from previous employers, they are likley to be underestimated. 


\section{Figure 1: GDP growth and aggregate level of wage arrears in Ukraine}

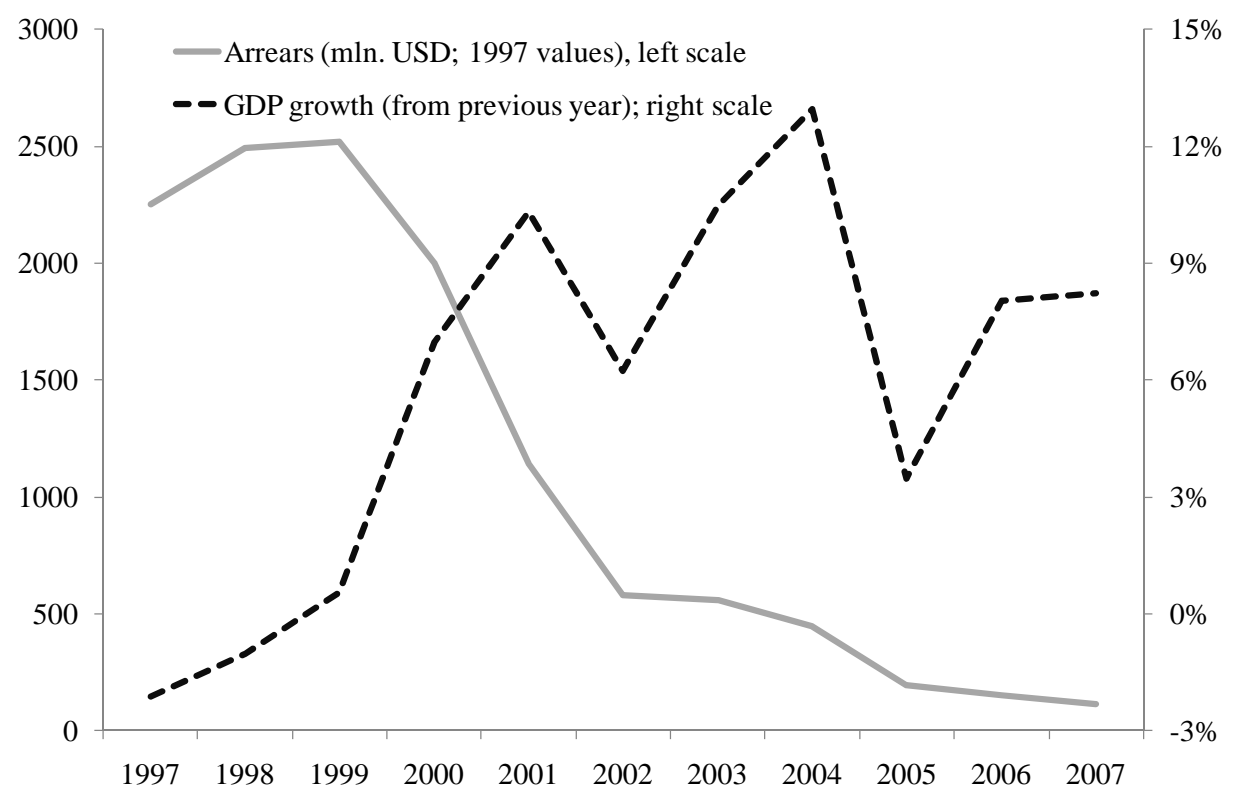

Note: Unfortunately, no official statistics exist on wage arrears prior to 1997. Source: State Statistics Committee of Ukraine (http://www.ukrstat.gov.ua/), own calculations.

The repayment of arrears is one aspect that has been largely ignored in the literature. Such paybacks did not only happen to employees who suffered from wage arrears with their current employer but also to former employees who had left the firm in the past. Observations from employer records and employee data indicate that repayments were "occasional and lumpy” (Earle, Spicer and Sabirianova, 2004: 6). As no general bargaining process about the repayment of wage arrears took place in Ukraine, the repayment decision has been taken by the firm management on a monthly basis. So, depending on the predominant nature and cause for wage arrears (liquidity constraints and/or managerial behavior), the repayment decision might or might not be at the manager's discretion. ${ }^{14}$ From the perspective of the individual these repayments can be considered unanticipated. Some employees might not even work in the indebted firm any longer and still receive a repayment. If negative wage shocks had a causal and positive impact on secondary activities and if these activities were predominantly used to fill the earnings gap, the repayment of wage shocks should have the opposite effect on

\footnotetext{
${ }^{14}$ A simple test of the randomness of repayments is performed with the data set and variables described below: In a multivariate regression of the determinants of arrear repayments, none of the various demographic, job, firm and regional controls delivers a coefficient that is significantly different from zero at the 5 percent level. This indeed suggests that repayments had little structure.
} 
labor supply. Thus, using repayment information as the analogue of wage shocks permits shedding light on the true motivation for second job holdings.

\subsection{Secondary Activities}

Generally, work relations are still relatively inflexible in Ukraine. The main source of rigidity is the strict Labor Code which has been in place since the Soviet era and which regulates the working week to comprise 40 hours. Part-time arrangements are still the exception. However, there are two sources of flexibility in the labor market: On the one hand, there are increasing numbers of opportunities for employees to engage in second jobs in dependent employment. Most second jobs comprise professional occupations (43\%), followed by manual (34\%) and service occupations (23\%). The sectors were most second job employers operate are education, sales and maintenance, health, and other service activities (56\%), agriculture (19\%), transport (8\%), construction (6\%) and are available throughout the country; however, while only $1.6 \%$ of employees in villages hold a second job, the fraction is typically much larger in towns and urban areas with up to $13.6 \%$ of employees in some cities. On the other hand, many Ukrainians have opportunities for growing food on household plots (subsidiary farming). Plot farming has a long tradition in Ukraine and other countries of the former Soviet Union and is widespread in rural areas. In villages, more than $90 \%$ of employees engage in at least some food production on a regular basis, while these numbers are much lower in large cities-for instance only $10 \%$ of employees in the cities of Lviv and Kiev. Farming requires access to plots and the availability of land naturally limits the potential to use farming as a coping strategy. While these limitations are serious in cities, availability of land is generally unproblematic in rural areas and small towns. ${ }^{15}$ Yet, starting to produce food as a response to wage shortfalls is probably limited. Therefore we may expect little response at the extensive margin for subsidiary farming (and if so only in areas where access to land is good and prior engagement in farming imperfect, i.e. in small towns). More easily, members of households that are already engaged in subsidiary farming could potentially expand their activities (given that the survey was predominantly collected during the agricultural season).

\footnotetext{
${ }^{15}$ Due to a land sale moratorium, most plots are rented in.
} 


\section{Data and Descriptive Statistics}

Most of the following analysis rests on two waves from a relatively new panel data set, the nationally representative Ukrainian Longitudinal Monitoring Survey (ULMS) for the years 2003 and 2004. The ULMS is a rich data source combining individual level information on socio-demographic characteristics with extensive labor-related data (Lehmann and Terrell, 2006). ${ }^{16}$ In addition, a household questionnaire collects rich information on household composition, assets, income and consumption. ${ }^{17}$ After carefully cleaning the data and restricting the sample to a balanced panel of prime age employees (17 to 60 years) who are working throughout both waves, 1,736 individuals per year provide complete employment and working hours information. Professional farmers, self-employed and family helpers are excluded from the sample as wages and hence wage shocks are harder to define in their cases. All individuals in the sample are employed and have worked for at least one hour in the reference week and were paid or supposed to be paid a wage. ${ }^{18}$ This implies the exclusion of employees on sick or maternity leave or in holidays. A variable overview for the sample can be found in Table A1.

Additional data come from cross-sectional waves of the nationally representative Ukrainian Household Budget Survey (UHBS) which collects information on 25,000 individuals and 9,000 households on an annual basis. The data comprise a rich set of individual and household characteristics, information on employment as well as incomes. The UHBS is here mainly used for estimating wage shock exposure and for imputing household consumption. It provides information which is highly comparable to that of the ULMS but includes more accurate indicators for outstanding wages from current and previous employers.

\footnotetext{
${ }^{16}$ The data were collected using multi-stage random sampling. If households moved between years, they were not followed across administrative regions (oblasts).

${ }^{17}$ In 2003, information on household consumption was collected only rudimentary. Thus household consumption values for 2003 and 2004 are imputed from the extensive questionnaire on food, service and durables consumption in UHBS. This questionnaire is highly comparable to the one used in the ULMS household survey in 2004. To check the robustness of the imputations for 2004, consumption values from UHBS and ULMS for that year are compared indicating a very strong positive correlation (coefficient: 0.663 ; the $\mathrm{R}^{2}$ in a simple regression is above 99 percent).

${ }^{18}$ The overall share of employed persons in the survey rose from 45.7 percent to 47.3 percent between 2003 and 2004.
} 


\subsection{Wage Shock and Labor Supply Variables}

Wage uncertainty is measured by worker-specific wage shocks which are defined as wage payments that fall short of the contractual wage despite the fulfillment of contractual work requirements. In other words, employees who report working normal hours in the reference week (normal in comparison to their 'work effort in an ordinary working week') but are paid no or a significantly lower wage than the contractually fixed amount and who report that their employer owes them wage income, are classified as individuals suffering from wage arrears. As also found for Russia (Earle and Sabirianova, 2002), wage arrears in the ULMS data set exhibit a strong regional character. While some regions have a wage arrears incidence of below 1 percent, up to 52 percent of employees were still affected in other areas in the 2003/2004 period. The variation across sectors is also substantial. While 'only' 4 percent of employees in public administration suffered from wage arrears, more than every third agricultural worker was affected (Table 1). Also, the conditional stock of back wages ranges regionally from around one up to six months and was especially high in the transport, agricultural and construction sectors.

Table 1: Wage arrears and secondary activities across sectors, 2003-2004

\begin{tabular}{lcccc} 
& $\begin{array}{c}\text { Share of } \\
\text { workforce with } \\
\text { wage shock }\end{array}$ & $\begin{array}{c}\text { Conditional } \\
\text { number of } \\
\text { monthly wages } \\
\text { in arrear }\end{array}$ & $\begin{array}{c}\text { Second job } \\
\text { holding }\end{array}$ & $\begin{array}{c}\text { Subsidiary } \\
\text { farming job }\end{array}$ \\
\hline Agriculture & $35.0 \%$ & 3.7 & $2.0 \%$ & $85.8 \%$ \\
Industry & $14.5 \%$ & 2.1 & $2.1 \%$ & $57.8 \%$ \\
Electricity & $12.8 \%$ & 0.9 & $2.6 \%$ & $64.4 \%$ \\
Construction & $5.6 \%$ & 2.7 & $2.8 \%$ & $50.0 \%$ \\
Sale & $4.7 \%$ & 1.5 & $2.5 \%$ & $48.9 \%$ \\
Transport & $6.2 \%$ & 5.9 & $2.3 \%$ & $65.5 \%$ \\
Financial services & $8.5 \%$ & 2.2 & $4.3 \%$ & $38.3 \%$ \\
Public administration & $4.1 \%$ & 0.6 & $3.7 \%$ & $63.0 \%$ \\
Education & $4.3 \%$ & 0.8 & $2.7 \%$ & $65.6 \%$ \\
Other Services & $8.4 \%$ & 1.6 & $2.8 \%$ & $50.2 \%$ \\
Other & $6.9 \%$ & 2.0 & $0.0 \%$ & $42.1 \%$ \\
\hline
\end{tabular}

Note: 3,472 observations. Source: ULMS, own calculations.

As all individuals in the sample are employed in their main job, labor supply is measured at the extensive margin by focusing on the participation decision in secondary activities. Table 1 reveals that second job holdings are much less common than subsidiary farming jobs, but both can be found across all economic sectors. At the intensive margin of labor supply, working hours in the secondary activities are analyzed along with main job and 
leisure hours. To impose as few assumptions as possible, leisure is defined as residual day time. The computation subtracts from 24 hours: eight hours of sleep, the working hours in main job, the working hours in other jobs and the time used for household food production. Although consistency in the time use data was checked carefully and individuals who report more than 99 hours of total work per week (including all sources of work) were excluded, some individuals end up with slightly negative leisure per day. In general, the calculation might still be correct, given that some individuals simply need less than eight hours for sleep and personal care per day. Nevertheless, a strict minimum of 0.1 hours of leisure per day is imposed in the analysis.

\subsection{Control Variables}

All regressions include as control variables individual characteristics (gender, age, age squared/100, years of education, marital status) as well as regional (oblast) and settlement type fixed effects and a common trend. To account for the time budget constraint and exceptional work load during the reference period the natural logarithm of hours worked in the main job is added as control. Further covariates include job characteristics (economic sector of work, enterprise ownership ${ }^{19}$ ), different income measures (log of non-labor income, the hourly wage rate and the second job shadow wage ${ }^{20}$ ) and a wealth (asset) indicator. Some attention should be paid to the construction of the income, wage and welfare variables. As a main job specific control variable, the hourly wage rate is constructed from contractual monthly wage income divided by contractual monthly working hours. This variable thus reflects how well a job would be paid under normal working and payment conditions. The analysis accounts for non-labor income by using total consumption net of all members’ labor incomes. To use household consumption rather than income helps to clean the analysis from regular consumption smoothing activities (e.g. continuous household production of food from small agricultural land plots) (cp. Blundell and MaCurdy, 1999). Furthermore, given that in some households not all working age members provided income information (for reasons like

\footnotetext{
${ }^{19}$ A variable indicating union membership status was not used in the regressions as it never came out significant.

${ }^{20}$ The second job wage rate is obviously unobserved for those not holding a second job. Therefore a reduced form regression of the second job wage rate for second job holders is performed in order to predict a shadow wage for the entire sample. This procedure may later introduce selectivity bias as actual wages offered to those not holding a second job might be structurally lower than the ones offered to second job holders. As a consequence of this overprediction $\mu_{2}$ will be biased towards zero. Different from studies where individuals are predominantly hours constrained (Shishko and Rostker, 1976) the second job wage rate should play little role in this setting. All regressions have also been performed devoid of the second job shadow wage without any impact on the results.
} 
absence at the interview date or refusal to participate in the survey), consumption seems the more reliable measure. Household wealth is controlled for by a composite measure of ten durable goods (e.g., refrigerator, washing machine, car etc.). Using principle component analysis, the set of assets is transformed into an asset indicator which accounts for more than 57 percent of the overall variance in asset holdings. The correlation matrix of single assets with the first principal component is reported in Table A2.

\section{Methodology}

\subsection{The Labor Supply Equation}

The main challenge of this research is to draw inference about the causal impact of unanticipated wage shocks on labor supply. If wage shocks $\gamma$ were purely random, one could simply compare the change in second job holdings $y$ (second job or subsidiary farming) over time between those employees 'treated' with a wage shocks $(\gamma=1)$ and those without a wage shock $(\gamma=0)$. Including as covariates the wage rates $w_{1}, w_{2}$ from the main and second job ${ }^{21}$ and household wealth $A$ as well as individual characteristics $X$ and firm and region controls $J$ gives the following formulation of the labor supply equation:

$y_{i t}=\alpha+\beta^{\prime} X_{i t}+\delta_{1} \gamma_{i t}+\delta_{2} d_{t}+\mu_{1} w_{1 i t}+\mu_{2} w_{2 i t}+\mu_{3} A_{i t}+\sigma^{\prime} J_{i t}+\varepsilon_{i t}$

for $\quad i \in\{1, \ldots, \mathrm{n}\}, t \in\{2003,2004\}$

The estimator of interest $\delta_{1}$ compares the conditional propensity of holding a second job between individuals who experienced a wage shock with those without shock. As we expect wage shocks to push workers into second jobs, $\delta_{1}$ should carry a positive sign. The period dummy $d_{t}$ captures general time trends like nationwide changes to the demand for and acceptability of second job holdings (e.g. employers in Ukraine might be increasingly ready to employ workers on the basis of contracts with few hours per week). Initially, equation (1) is estimated in a pooled OLS set-up with individual clustered standard errors. The hours equation makes use of a normal rather than a log-log specification to implicitly account for non-participation (Angrist and Krueger, 1999; Blundell and MaCurdy, 1999) and is estimated with a censored Tobit model with clustered standard errors. Such a model assumes that the

\footnotetext{
${ }^{21}$ No shadow wage has been imputed for subsidiary farming as producer food prices are unavailable.
} 
participation decision and the hours decision are produced by the same econometric process and that individuals who do not supply any labor to a second job simply chose zero hours. To test the robustness of the estimated effects, two model specifications are used throughout all main results. The first model employs only pre-determined demographic characteristics like age, gender, education and pre-determined location controls. The second model is being nested in the first and removes the parameter restrictions on all other covariates by adding all remaining individual and job characteristics as well as measures for non-labor income and asset wealth. $^{22}$

All estimates might be biased if unobservable (and thus uncontrolled) factors influenced both, the probability to suffer from a wage shock and the probability to take on a second job. As a start, it is useful to think about the character of this bias and detect the potential direction of its impact. One would expect that firm managers might impose wage arrears on their less productive workers first, thus discriminating between workers of different levels of ability or conscientiousness. The firm manager might be doing so, as she is able to observe what remains unobservable to the researcher. In general, we expect that low levels of ability or conscientiousness are negatively correlated with holding a second job, as second job employers value similar characteristics as main job employers. Then, however, estimates which cannot adequately account for unobservables should be downward rather than upward biased.

Using panel data permits to control for unobservable individual characteristics. So, the main econometric specification will account for individual heterogeneity by estimating (1) as a fixed effects panel data model. In this way it is possible to remove any time-invariant factors which potentially bias standard OLS. For the analysis of second job working hours, the preferred model is the random-effects Tobit panel model. ${ }^{23}$

In order to take into account the possibility of measurement error in the shock variable, a more comprehensive wage arrear measure from the larger UHBS data set is exploited: it contains information on outstanding wages in the current job (as in the ULMS) as well as from previous jobs. Similar to the ULMS, the UHBS asks respondents to indicate the

\footnotetext{
${ }^{22}$ In order to test whether the more complex nested model has additional explanatory power, likelihood ratio (LR) tests are performed for the main tables. The reported p-values refer to the hypothesis that the simpler model is a valid representation for the nested model. In all cases, the LR test suggests the superiority of the more complex specification.

${ }^{23}$ In addition a fixed-effects linear panel model is employed in order to show the robustness of the results for second job hours. This, however, estimates responses to wage shocks for the uncensored sample and will deliver coefficients that cannot be converted into effects for the sample under consideration (therefore these results are reported for illustrative purposes in Table A3 in the Appendix). It should be noted that censoring is strong for second jobs but not for subsidiary farming.
} 
volume of outstanding wages while providing a much larger sample size. Hence wage shocks can be measured quite accurately. The general model is again:

$y_{i t}=\beta^{\prime} X_{i t}+\delta_{1} \gamma_{i t}+\alpha_{i}+\varepsilon_{i t}$

As this model is endangered to suffer from incorrectly measured wage shock information $\gamma$, an instrument $Z$ is employed. As the measurement problem cannot be solved in the ULMS data set, auxiliary data (the UHBS) are used from which one can impute the wage shock risk for the ULMS. The incidence of complete wage shocks (including arrears from previous employers) is regressed on sector and region dummies in the UHBS data and then predicted for ULMS observations as an instrument for wage uncertainty. ${ }^{24}$ In order to estimate the parameter of interest $\left(\delta_{1}\right)$ in the second stage, the first stage exploits the conditional relationship between the observed wage shock variable and the assigned wage risk information:

$\gamma_{i t}=\beta^{\prime} X_{i t}+\lambda Z_{i t}+u_{i t}$

This instrumental variable approach is estimated with generalized two-stage least squares estimation (G2SLS) for panel data. As will be shown below, a Hausman test suggests a preference for the more efficient random-effects panel model.

Albeit panel and IV methods correct different kinds of biases here, neither is as conceptually straightforward as a quasi-experiment. One such experiment is represented by the exogenous repayment of outstanding wages. Luckily, the availability of pay-back information in Ukraine offers the unique opportunity to exploit exogenous variation in firms' wage policies to understand the effect of wage shocks at the employee level over the entire cycle of wage shocks. ${ }^{25}$

\footnotetext{
${ }^{24}$ A matrix of 26 regions and 12 economic sectors is used in order to estimate wage shocks. To check the estimation fit in the prediction sample, a cross-validation of the prediction quality is performed by splitting the UHBS sample randomly and predicting the respective variable for the second part of the sample. The crossvalidity coefficient of both sub samples is of reasonable size $(+0.35)$.

${ }^{25}$ In the UHBS data, 14 percent of repayments are directed to employees who have wage arrears with their current employer, while the substantial remaining share is received by those who have no arrears with the current but a former employer.
} 


\subsection{The Consumption Smoothing Equation}

The final part of this paper addresses the question how successful credit constrained households use secondary activities to smooth consumption. If the estimated effect of wage shocks on labor supply was causal (i.e. employees ultimately respond to wage shocks) the consumption smoothing mechanism of second job holdings should be traceable in the data. Similar to the previous literature, this paper uses a household fixed effects consumption model which can be consistently estimated even in a two-period set-up (Attanasio and Székely, 2004):

$$
\Delta \log c_{j}=\delta_{1} \Delta \log y_{j}+\delta_{2} \Delta s_{j}+\delta_{3} \Delta l_{j}+\delta_{4} \Delta\left(l_{j}^{*} s_{j}\right)+\delta_{5} \Delta\left(f_{j}^{*} s_{j}\right)+\beta{ }^{\prime} \Delta X_{j}+\varepsilon_{j} \quad ; j \epsilon\{1, \ldots, \mathrm{n}\}
$$

Under the absence of any consumption smoothing, the coefficient $\delta_{1}$ is expected to converge to one, as consumption of household $j$ perfectly covaries with available income. In perfect insurance markets, the coefficient should not be different from zero, as consumption is entirely independent of income. Furthermore, if insurance mechanisms were fully at work, transitory shocks $s_{j}$ should have no impact on the level of consumption, thus the coefficient of wage shocks $\delta_{2}$ should be zero. On the other hand, if the coefficient is statistically significant different from zero and negative, transitory shocks seem not only to be unanticipated but also ex-ante uninsurable. At the centre of interest here are the terms reflecting the response to shocks $\left(l_{j}^{*} s_{j}\right)$ and $\left(f_{j}{ }^{*} s_{j}\right)$ where $l_{j}$ is an indicator for second job holdings and $f_{j}$ for subsidiary farming. The sign of $\delta_{4}$ and $\delta_{5}$ contains information on whether households that respond to wage shocks by increasing their labor supply in a second activity can compensate for the income loss and smooth out consumption. If $\delta_{2}+\delta_{3}+\delta_{4}+\delta_{5}<0$, households cannot entirely shield their consumption against wage shocks. If $\delta_{2}+\delta_{3}+\delta_{4}+\delta_{5}=0$, households exactly compensate for their income loss and if $\delta_{2}+\delta_{3}+\delta_{4}+\delta_{5}>0$, households are on average able to overcompensate their loss. The fixed effects regressions also control for household size and regional characteristics like access to finance ${ }^{26}$, which are subsumed under $X$.

\footnotetext{
${ }^{26}$ Access to finance is measured as the regional share of households who either use a savings or lending facility at a bank. It should be noted, that households might potentially use savings to smooth out consumption. However, the Russian financial crisis of 1998/1999 depleted most of these savings.
} 


\section{Results}

The results of the empirical analysis are presented and discussed in the following order: The first subsection provides a descriptive overview of the relationship between and the determinants of the main variables of interest-wage shocks and secondary activities. Then the causal effect of wage shocks on second job holdings is estimated, before the analysis proceeds to the implementation of an IV approach in order to account for measurement error. The final subsection turns to the role of wage shocks and coping mechanisms in the consumption smoothing framework.

\subsection{Descriptive Statistics}

Those who currently suffer from a wage shock are more likely to engage in a secondary activity. The top panel of Table 2 indicates that employees who experience wage arrears have a 72 percent higher incidence of second jobs and a 12 percent higher incidence of farming activities. Also working hours are significantly higher for employees with wage shocks.

Wage arrears are not very persistent over time and across individuals. Panel B. of Table 2 shows that entry to and exit from wage arrears status are substantial between the years. Well above half of employees who suffered from a wage shock in 2003 do not report any similar incidence in 2004, while 4 percent of employees without previous shocks experience wage arrears in 2004. The substantial variation of wage arrears across individuals over time is a crucial prerequisite for the outlined estimation strategy. It suggests that shocks were not permanently concentrated among the same employees. Given the strong growth of the economy in the early 2000s (see Figure 1) employees were probably not expecting wage shocks in a way they might have been prepared for during the period of high shock incidence in the 1990s. The crucial issue of employees' anticipation will be more thoroughly addressed in Section 6 of this paper.

Panel C. of the table shows the share of employees holding a second job in 2004 by the same four cells of the wage arrears matrix. It becomes evident that those who have no wage arrears in 2004 are less likely to engage in a second job, no matter whether they suffered from insecure income in 2003. Their share of second job holders is around 2 percent. Employees who suffer from wage shocks in both years are more likely to hold a second job (2.7 percent). However, the highest second job holdings are recorded for those who have wage shocks in 2004 but not in 2003. Six percent of them have a second job, suggesting that the non-anticipated incidence of shocks might be the main driving force behind the observed 
labor supply pattern. The pattern for subsidiary farming is quite different: Rather than current shock incidence, last year's experience seems to matter. This might be plausible given the difficulties in land access and the inflexibility inherent to this coping strategy. ${ }^{27}$ Although these unconditional results suggest that secondary activities and wage shocks are related, they do not imply any causal relationship so far.

Before proceeding to the estimation of the shock response model it seems crucial to gain a better understanding of the general determinants of second job holdings and wage arrears. The determinants of wage shocks can shed light on whether arrears exhibit a pattern of regional and sectoral concentration, as suggested by the previous literature on Russia. Similarly, the determinants of secondary activities can suggest whether this kind of employment is predominantly used by specific groups of employees.

Table 3 shows determinants of wage arrears in Ukraine based on a simple pooled Probit model with individually clustered robust standard errors. Wage shocks are weakly associated with gender and are more common among workers in their late 40s. The latter finding is intuitive as the bonding effect exerted by arrears is stronger for older workers who have already invested more in job and firm specific skills. Better off employees seem to have a lower propensity to face wage arrears as indicated by the negative coefficient of the asset variable. The main determinants of wage shock, however, seem to be region, sector and firm effects with patterns that are in line with the previous literature (cp. Lehmann, et al., 1999).

The table also provides evidence on the determinants of secondary activities. Given that overall only about 3 percent of employees hold a second job, the marginal effects are small. Human capital and wealth are the main determinants of second job holdings, while farming activities are correlated with region and sector characteristics. As expected, the imputed second job shadow wage is positively correlated with second job holdings, but the effect is almost negligible in size. An increase in the average second job hourly wage rate from $10 \mathrm{UAH}$ by $1 \mathrm{UAH}$ (a plus of ten percent) would only imply an increase in the propensity of holding a second job by 1.3 percent. Individual characteristics like gender, age and marital status seem to play no significant role for second jobs but for subsidiary farming activities where women and older workers are more likely to be engaged in. ${ }^{28}$ Two aspects deserve special attention. First, employees who work fewer hours per week are more likely to

\footnotetext{
${ }^{27}$ Having started a farming activity in the past might require further labor input beyond the termination date of the shock. Such prolonged coping seems quite realistic given that the average shock lasts around five months while the agricultural season might be longer.

${ }^{28}$ An additional specification shows that married women are less likely to hold a second job.
} 
perform a subsidiary activity. As will be shown later, this coefficient reflects a labor substitution between main job and coping activity in the presence of wage shocks rather than additional activities of workers who are involuntarily time constrained in the main job. Second, non-labor household income and assets promote secondary activities. While both coping strategies might be used against wage uncertainty in the main job, second jobs are more common among the better-off and farming jobs are more widespread in rural areas.

Table 2: Incidence and intensity of secondary activities by wage shock status

\begin{tabular}{|c|c|c|c|}
\hline Panel A. & & & \\
\hline Participation in & Second job holdings & Subsidiary farming & \\
\hline Currently no wage arrear & $2.2 \%$ & $60.7 \%$ & \\
\hline Currently wage arrear & $3.8 \%$ & $68.6 \%$ & \\
\hline$\Delta$ & $\begin{array}{c}1.6 \% \\
(0.008)^{* *}\end{array}$ & $\begin{array}{c}7.8 \% \\
(0.027)^{* * *}\end{array}$ & \\
\hline Hours worked per week in ${ }^{a}$ & Second job & Subsidiary farming & \\
\hline Currently no wage arrear & 4.5 & 15.2 & \\
\hline $\begin{array}{l}\text { Currently wage arrear } \\
\Delta\end{array}$ & $\begin{array}{c}7.6 \\
3.1 \\
(1.10)^{* * *} \\
\end{array}$ & $\begin{array}{c}20.0 \\
4.8 \\
(0.96)^{* * *}\end{array}$ & \\
\hline \multicolumn{4}{|l|}{ Panel B. } \\
\hline Transition matrix & No wage arrear 2004 & Wage arrear 2004 & Total \\
\hline No wage arrear 2003 & $96.0 \%$ & $4.0 \%$ & $100 \%$ \\
\hline Wage arrear 2003 & $56.9 \%$ & $43.1 \%$ & $100 \%$ \\
\hline
\end{tabular}

Panel C.

Second job holdings in 2004

No wage arrear $2004 \quad$ Wage arrear $2004 \quad \Delta$ within row

\begin{tabular}{lccc} 
No wage arrear 2003 & $2.2 \%$ & $6.0 \%$ & $3.8 \%$-p. $(0.014)^{* * *}$ \\
Wage arrear 2003 & $2.4 \%$ & $2.7 \%$ & $0.3 \%$-p. $(0.015)$ \\
$\Delta$ within column & 0.3\%-p. $(0.010)$ & $-3.2 \%$-p. $(0.023)^{*}$ & \\
\hline
\end{tabular}

\section{Subsidiary farming in 2004}

No wage arrear 2003

No wage arrear 2004

Wage arrear 2004

$\Delta$ within row

Wage arrear 2003

$60.3 \%$

$64.4 \%$

$66.7 \%$

4.1\%-p. (0.046)

$70.6 \%$

2.3\%-p. (0.056)

$-3.9 \%-p .(0.045)$

$\Delta$ within column

$10.2 \%-p .(0.032) * * *$

Note: Based on balanced panel of 3,472 observations. Source: ULMS, own calculations. 
Table 3: Determinants of wage arrears and secondary activities

(1)

Wage arrear

Probit

$(0.012)$

$0.010 * *$

$(0.004)$

$-0.011^{* *}$

$(0.005)$

$0.004 *$

$(0.002)$

$0.083^{* *}$

$(0.043)$

West

0.039

$(0.039)$

East

$0.133 * * *$

(0.046)

South

Asset indicator

Log of non-labor income

0.048

$(0.038)$

$-0.010 * * *$

$(0.004)$

0.001

(0.003)

Log of main job working hours

Second job shadow wage

Industry

Education

Agriculture

De novo private firm

Village

Town

Time

Pseudo R-squared

Observations

(0.027)

$-0.047 * *$

$$
\text { (0.018) }
$$

$0.208 * * *$

(0.052)

$-0.037 * *$

$(0.012)$

$-0.006$

$-0.013$

(0.013)

(0.007)
(2)

(3)

Second job holding Subsidiary farming

Probit Probit

$0.003 \quad 0.044^{*}$

$(0.004)$

$(0.024)$

0.002

$0.018 * *$

$(0.002)$

$(0.008)$

$-0.002$

$-0.015$

$(0.002)$

$(0.010)$

$0.002^{* *}$

0.003

$(0.001)$

$(0.005)$

$-0.006$

$0.323 * * *$

$(0.008)$

(0.038)

0.017

(0.016)

$0.316^{* * *}$

0.002

(0.036)

(0.009)

$0.326 * * *$

0.012

(0.039)

(0.012)

$0.252^{* * *}$

0.002

(0.044)

(0.002)

$0.014 *$

(0.008)

$0.007 * * *$

$-0.000$

(0.002)

(0.006)

$-0.012 * *$

(0.005)

$-0.086^{* * *}$

$0.0005 *$

(0.032)

(0.0003)

0.001

0.003

(0.001)

(0.010)

$0.087 * *$

0.000

(0.038)

$(0.010)$

$0.085 * *$

0.010

(0.037)

(0.017)

$0.119 * *$

0.008

(0.045)

(0.010)

$-0.069 *$

$-0.003$

(0.036)

(0.006)

$0.454^{* * *}$

0.001

(0.018)

(0.005)

$0.235^{* * *}$

(0.021)

0.002

$-0.042 * * *$

(0.003)

(0.015)

0.023

0.237

3472

3472

Note: Marginal effects reported. Base categories are 'Kiev region', 'large city', 'state enterprise', 'service sector'. All other coefficients on 'married', 'privatized firm', 'national/international organization', 'Electricity', 'Construction', 'Sale', 'Transport', 'Administration', and 'Finance' sector were insignificant. Robust standard errors clustered by individual ID are reported in parentheses. ${ }^{* * *} \mathrm{p}<0.01,{ }^{* *} \mathrm{p}<0.05,{ }^{*} \mathrm{p}<0.1$. Source: ULMS, own calculations. 


\subsection{Estimating the Effect of Wage Shocks on Secondary Activities}

In the following we turn to the response of secondary activities to transitory wage shocks. Table 4 reports results for different measures of wage arrears: a binary variable indicating the presence of a shortfall of wages due to arrears (wage shock), the intensity of wage shocks (measured as stock of outstanding monthly wages), an indicator for the receipt of wage repayment ${ }^{29}$ and an indicator for the receipt of other positive wage shocks. The table shows only the marginal effects of interest from regressions with several specifications. The top panel comprises results for the naive pooled OLS estimation of equation (1), while the bottom contains results from fixed effects regressions. Columns 1 and 3 control only for exogenous demographic factors, while columns 2 and 4 add the remaining demographic, job and welfare controls. The complete list of estimated coefficients of all regressors is provided in Tables A4, A5a and A5b in the Appendix, which also contains the results based on specification-specific maximal samples.

Second job holdings are 2.3 percentage points higher among employees with wage shocks and these results are hardly affected by the inclusion of job and wealth controls. The coefficient on shock intensity is positive, yet, insignificant. On the opposite, the repayment of back wages significantly lowers the propensity to work in a second job and, interestingly, the size of the coefficient is almost identical to the coefficient indicating the incidence of a wage shock. Although these estimates are no more than correlations so far, this pattern might suggest that the onset of a shock increase second job holdings, while the termination of the shock reduces second jobs by the same rate. Such a co-movement of second job holdings with wage arrears might be an indicator for a causal relationship. Finally, the analysis investigates whether the repayment effect on second job holdings is simply driven by higher incomes. If this was the case, higher than usual wage payments like bonus payments or gratuities should have a similarly discouraging effect on second job holdings. However, positive wage shocks other than wage repayments seem to be uncorrelated with second job holdings. Although all estimates for subsidiary farming show the expected signs none of them is significant in this specification.

If unobservable ability was negatively related to the propensity to suffer from a wage shock but positively correlated to the propensity of holding a second job, the coefficients from pooled OLS would be downward biased. As described earlier, the omitted variable $(O V)$ is

\footnotetext{
${ }^{29}$ Wage repayment means the explicit repayment of owed wages, not the return to scheduled monthly payment.
} 
expected to be negatively correlated with wages shocks but positively correlated with second job holdings. As the estimated coefficient on wage shocks in (1) is positive $(\operatorname{Corr}(O V, \gamma)<0$ and $\left.\delta_{1}>0\right), \delta_{1}$ suffers from a negative bias. To account for this unobservable ability, fixed effects are included in the estimation. The results reported in the lower panel of Table 4 show that the causal impact of wage arrears on second job holdings becomes substantially larger and remains statistically significant compared to OLS. ${ }^{30}$ Depending on the specification, the coefficient is 13 to 22 percent larger when accounting for unobserved heterogeneity. As Table 4 further reveals, the intensity of wage shocks becomes now highly significant indicating that each additional month of outstanding wages increases the probability of holding a second job by 0.6 percent. The coefficient from the wage shock dummy specification is 4.7 times larger than the coefficient in the intensity regressions, indicating that the average employee suffering from a wage shock is owed 4.7 monthly wages. This number is indeed quite close to the conditional sample mean for the shock intensity (see Table A1). The effect of wage repayment becomes much larger in the fixed effects regression while other forms of positive wage shocks remain insignificant, underlining that the estimated effects on second job holdings cannot be simply attributed to additional income.

The incidence of wage shocks in the main job has a strong and positive significant effect on subsidiary farming activities of employees residing in towns. The propensity to engage in farming ranges between 13 and 16 percent. None of the intensity, repayment or positive wage shock estimates turns out to be significant. While this might indicate that individuals with access to land enter a continuous coping strategy, the lack of precision might also stem from the limited size of the respective subsample.

\footnotetext{
${ }^{30}$ The effect is significant in villages and towns as well as in large cities, where it is strongest (Table A7).
} 
Table 4: Impact of wage shocks on secondary activities (extensive margin)

\begin{tabular}{|c|c|c|c|c|c|c|c|c|c|c|c|c|c|}
\hline \multirow{2}{*}{\multicolumn{2}{|c|}{ Dependent variable }} & \multirow{3}{*}{$\begin{array}{c}(1) \\
\text { Marg.eff. } \\
\text { (std.er.) }\end{array}$} & \multirow{3}{*}{\multicolumn{2}{|c|}{\begin{tabular}{ll}
\multicolumn{2}{l}{} \\
\multicolumn{2}{l}{ Second job holding } \\
R- \\
Squared
\end{tabular}}} & \multirow{3}{*}{$\begin{array}{c}(2) \\
\text { Marg.eff. } \\
\text { (std.er.) }\end{array}$} & \multirow{2}{*}{\multicolumn{3}{|c|}{ (3) }} & \multicolumn{5}{|c|}{ (4) } \\
\hline & & & & & & & & & \multicolumn{5}{|c|}{ Subsidiary farming job } \\
\hline & Shock variable & & & & & $\begin{array}{c}\text { R- } \\
\text { Squared }\end{array}$ & $\begin{array}{c}\mathrm{LL}^{\mathrm{a}} \\
\text { (Prob > } \\
\text { Chi2) }\end{array}$ & $\begin{array}{l}\text { Marg.eff. } \\
\text { (std.er.) }\end{array}$ & $\begin{array}{c}\text { R- } \\
\text { Squared }\end{array}$ & $\mathrm{LL}^{\mathrm{a}}$ & $\begin{array}{l}\text { Marg.eff. } \\
\text { (std.er.) }\end{array}$ & $\begin{array}{c}\text { R- } \\
\text { Squared }\end{array}$ & $\begin{array}{c}\mathrm{LL}^{\mathrm{a}} \\
\text { (Prob > } \\
\text { Chi2) }\end{array}$ \\
\hline \multirow[t]{4}{*}{ OLS model } & Wage shock & $\begin{array}{c}0.023 * * \\
(0.011)\end{array}$ & 0.016 & & $\begin{array}{l}0.024 * * \\
(0.011)\end{array}$ & 0.020 & & $\begin{array}{c}0.009 \\
(0.046)\end{array}$ & 0.103 & & $\begin{array}{c}0.017 \\
(0.047)\end{array}$ & 0.126 & \\
\hline & Intensity of shock & $\begin{array}{c}0.004 \\
(0.003)\end{array}$ & 0.018 & & $\begin{array}{c}0.004 \\
(0.003)\end{array}$ & 0.022 & & $\begin{array}{c}0.003 \\
(0.003)\end{array}$ & 0.103 & & $\begin{array}{c}0.003 \\
(0.003)\end{array}$ & 0.126 & \\
\hline & Repayment & $\begin{array}{c}-0.021 * * \\
(0.009)\end{array}$ & 0.013 & & $\begin{array}{c}-0.025^{* * *} \\
(0.009)\end{array}$ & 0.018 & & $\begin{array}{l}-0.359 \\
(0.349)\end{array}$ & 0.104 & & $\begin{array}{l}-0.275 \\
(0.372)\end{array}$ & 0.126 & \\
\hline & Positive shock & $\begin{array}{c}0.035 \\
(0.034) \\
\end{array}$ & 0.014 & & $\begin{array}{c}0.019 \\
(0.034) \\
\end{array}$ & 0.018 & & $\begin{array}{c}0.027 \\
(0.137) \\
\end{array}$ & 0.103 & & $\begin{array}{c}0.011 \\
(0.134) \\
\end{array}$ & 0.126 & \\
\hline \multirow[t]{7}{*}{ FE model } & Wage shock & $\begin{array}{c}0.028 * * \\
(0.013)\end{array}$ & 0.007 & 3616.0 & $\begin{array}{c}0.027 * * \\
(0.013)\end{array}$ & 0.022 & $\begin{array}{l}3643.0 \\
(0.000)\end{array}$ & $\begin{array}{c}0.158 * * * \\
(0.060)\end{array}$ & 0.088 & 121.2 & $\begin{array}{c}0.128 * * \\
(0.064)\end{array}$ & 0.115 & $\begin{array}{c}134.6 \\
(0.0315)\end{array}$ \\
\hline & Intensity of shock & $\begin{array}{c}0.006 * * * \\
(0.002)\end{array}$ & 0.013 & 3627.3 & $\begin{array}{c}0.006 * * * \\
(0.002)\end{array}$ & 0.028 & $\begin{array}{l}3652.9 \\
(0.000)\end{array}$ & $\begin{array}{c}0.003 \\
(0.006)\end{array}$ & 0.073 & 114.4 & $\begin{array}{c}0.004 \\
(0.006)\end{array}$ & 0.107 & $\begin{array}{c}130.6 \\
(0.0055)\end{array}$ \\
\hline & Repayment & $\begin{array}{c}-0.202 * * * \\
(0.077)\end{array}$ & 0.008 & 3618.2 & $\begin{array}{c}-0.195^{* *} \\
(0.077)\end{array}$ & 0.024 & $\begin{array}{l}3645.2 \\
(0.000)\end{array}$ & $\begin{array}{l}-0.057 \\
(0.306)\end{array}$ & 0.073 & 114.2 & $\begin{array}{l}-0.111 \\
(0.354)\end{array}$ & 0.107 & $\begin{array}{c}130.4 \\
(0.0056)\end{array}$ \\
\hline & Positive shock & $\begin{array}{c}-0.027 \\
(0.028)\end{array}$ & 0.005 & 3612.8 & $\begin{array}{l}-0.025 \\
(0.028)\end{array}$ & 0.020 & $\begin{array}{l}3639.4 \\
(0.000)\end{array}$ & $\begin{array}{c}0.055 \\
(0.132)\end{array}$ & 0.073 & 114.3 & $\begin{array}{c}0.102 \\
(0.139)\end{array}$ & 0.108 & $\begin{array}{c}130.9 \\
(0.0045)\end{array}$ \\
\hline & $\begin{array}{l}\text { Demographic } \\
\text { controls }\end{array}$ & $\mathrm{X}$ & & & $\mathrm{X}$ & & & $\mathrm{X}$ & & & $\mathrm{X}$ & & \\
\hline & $\begin{array}{l}\text { Job \& welfare } \\
\text { controls }\end{array}$ & - & & & $\mathrm{X}$ & & & - & & & $\mathrm{X}$ & & \\
\hline & Observations & 3472 & & & 3472 & & & 874 & & & 874 & & \\
\hline
\end{tabular}

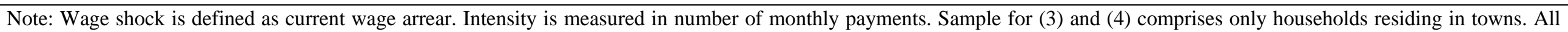

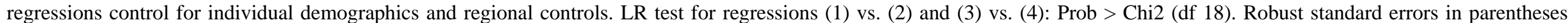

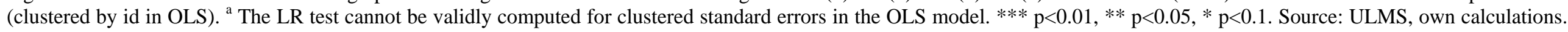


Beside the second job participation decision, wage shocks might prompt individuals to intensify their activities in a previously existing second job. Table 5 presents the results from the intensive labor supply margin in a Tobit and random-effects Tobit framework (for the full list of regressors see Table A6). Individuals who already held a second job increase their labor supply by around 5 hours following a wage shock (columns 1-4), a very consistent estimate across the different specifications. This implies on average a doubling of second job hours after a wage shock. Hours in subsidiary farming increase by 2.3 to 4.7 hours (columns 5-8). Interestingly, the relationship between main job hours and hours in the secondary activity is comparatively small. One additional hour in the main employment is associated with second job holdings that are on average only one eighth of an hour lower. The effect is twice as large in subsidiary farming. These results probably reflect the low variation in hours of main job employment relations, where the vast majority of labor contracts are fixed at forty hours.

From a policy perspective, it is relevant to understand the mechanism which underlies the increase in secondary activities or hours while employees are still employed in their main job. The question is whether workers simply add more effort and increase their overall working time at the expense of leisure or whether they re-allocate effort between jobs. On the one hand, it seems reasonable to assume that employees reduced main job effort in exchange for second job effort. On the other hand, the bonding effect of wage arrears might prevent them from reducing effort significantly or from quitting the main job altogether (as a corner solution). 
Table 5: Impact of wage shocks on working hours in secondary activities (intensive margin)

\begin{tabular}{|c|c|c|c|c|c|c|c|c|}
\hline \multirow{3}{*}{ Dependent variable } & (1) & (2) & (3) & (4) & (5) & (6) & (7) & (8) \\
\hline & \multicolumn{4}{|c|}{ Working hours in second job } & \multicolumn{4}{|c|}{ Working hours in subsidiary farming } \\
\hline & Tobit & Tobit & $\begin{array}{c}\text { RE } \\
\text { Tobit } \\
\end{array}$ & $\begin{array}{c}\text { RE } \\
\text { Tobit } \\
\end{array}$ & Tobit & Tobit & $\begin{array}{c}\text { RE } \\
\text { Tobit }\end{array}$ & $\begin{array}{c}\text { RE } \\
\text { Tobit }\end{array}$ \\
\hline Wage shock & $\begin{array}{c}4.761^{* * *} \\
(1.768)\end{array}$ & $\begin{array}{c}4.631^{* * *} \\
(1.779)\end{array}$ & $\begin{array}{c}4.729 * * \\
(1.852)\end{array}$ & $\begin{array}{c}5.066^{* * * *} \\
(1.917)\end{array}$ & $\begin{array}{c}4.661^{* * *} \\
(1.161)\end{array}$ & $\begin{array}{c}2.878 * * \\
(1.215)\end{array}$ & $\begin{array}{c}3.932 * * * \\
(1.257)\end{array}$ & $\begin{array}{c}2.293 * * \\
(1.112)\end{array}$ \\
\hline Main job hours & $\begin{array}{l}-0.100 * \\
(0.058)\end{array}$ & $\begin{array}{c}-0.102 * \\
(0.060)\end{array}$ & $\begin{array}{c}-0.129 * * \\
(0.062)\end{array}$ & $\begin{array}{c}-0.127 * * \\
(0.065)\end{array}$ & $\begin{array}{c}-0.200 * * * \\
(0.035)\end{array}$ & $\begin{array}{c}-0.231 * * * \\
(0.037)\end{array}$ & $\begin{array}{c}-0.212 * * * \\
(0.045)\end{array}$ & $\begin{array}{c}-0.240 * * * \\
(0.047)\end{array}$ \\
\hline Log non-labor inc. & & $\begin{array}{c}2.415^{* * * *} \\
(0.680)\end{array}$ & & $\begin{array}{c}2.483 * * * \\
(0.690)\end{array}$ & & $\begin{array}{l}-0.063 \\
(0.238)\end{array}$ & & $\begin{array}{l}-0.043 \\
(0.246)\end{array}$ \\
\hline Hourly wage main job & & $\begin{array}{c}0.083 \\
(0.370)\end{array}$ & & $\begin{array}{c}0.010 \\
(0.392)\end{array}$ & & $\begin{array}{c}-0.632 * * \\
(0.299)\end{array}$ & & $\begin{array}{l}-0.587 \\
(0.396)\end{array}$ \\
\hline Demographic controls & $\mathrm{X}$ & $\mathrm{X}$ & $\mathrm{X}$ & $\mathrm{X}$ & $\mathrm{X}$ & $\mathrm{X}$ & $\mathrm{X}$ & $\mathrm{X}$ \\
\hline Job \& wealth controls & - & $\mathrm{X}$ & - & $\mathrm{X}$ & - & $\mathrm{X}$ & - & $\mathrm{X}$ \\
\hline LL & -574.82 & -561.89 & -550.19 & -532.27 & -6287 & -6256 & -6224 & -6198 \\
\hline Prob > Chi2 (df 18) & & 0.0005 & & 0.0074 & & 0.0073 & & 0.0120 \\
\hline Pseudo R2 / Chi2 & 0.034 & 0.056 & 27.2 & 33.7 & 0.0319 & 0.0367 & 312.1 & 1161 \\
\hline Observations & 3472 & 3472 & 3472 & 3472 & 1834 & 1834 & 1834 & 1834 \\
\hline
\end{tabular}

Note: Share of uncensored observations: $2.35 \%$. The quadrature approximation of the RE Tobit model was checked using the 'quadchk' command in Stata. Sample for models (5)

to (8) comprises only households in towns and villages. Robust standard errors in parentheses; ${ }^{* * *} \mathrm{p}<0.01$, ** $\mathrm{p}<0.05$, * $\mathrm{p}<0.1$. Source: ULMS, own calculations. 
Furthermore, the hours constraint formulated earlier does not allow employees to provide unlimited additional effort while being still employed in the risky main job. Table 6 therefore also presents marginal fixed effects of main job hours and leisure with respect to wage shocks. Suffering from a wage shock reduces main job hours supply by roughly 5 percent (columns 13). Given that virtually all Ukrainians work 40 hours per week, the reduction of working time equals 1.9 hours per week. This reduction is smaller than the associated increase in second job labor supply implying that individuals must also reduce their available leisure time (columns 46). On a weekly basis, the reduction ranges between 3.4 and 3.6 hours, depending on the specification. Dividing the sample into three groups of individuals according to settlement type shows that the reduction in main job and leisure hours takes place predominantly in villages and towns where it amounts to minus 6.6 percent and minus 4.5 percent, respectively (Table A7). ${ }^{31}$ This is consistent with the availability of subsidiary farming opportunities in these areas.

So far we have seen that the incidence of wage shocks causes employees to engage in secondary activities, while the subsequent repayment of outstanding wages significantly reduces the likelihood of having a second job (but not of subsidiary farming). Table 7 adds another piece of evidence to this cycle of entry and exit from second jobs by looking at the timing of the events. While an adverse wage shock immediately reduces the disposable household income, the search for a second job opportunity or the start of farming activities might be time-consuming. Table 7 therefore reports current labor supply responses as a function of the timing of the shock. As before, a current wage shock has a positive impact on second job holdings of around 2 percent and a marginally insignificant effect on subsidiary farming. A shock that took place three to six months ago increases second job holdings and subsidiary farming twice as strong, probably reflecting the individuals' response time to the shock. Wage non-payments that arrived for the first time nine to twelve months ago have no significant impact on current secondary coping activities which appears reasonable given that wage shocks were relatively short lived (on average 5.2 months). Again, this labor supply response pattern supports the idea that second job holdings are co-moving with wage shocks.

\footnotetext{
${ }^{31}$ While the top panel of Table 6 does not account for the main job hourly wage, the bottom panel also includes job characteristics. One of these characteristics is the log of the contractual hourly wage rate. As this variable is endogenous, the mean wage of employees of a specific educational level in a specific industry is used as an instrument. The IV estimation produces relatively large standard errors. The Marshallian wage elasticity of main job working hours is negative but not statistically significant different from zero. It suggests that employees do not adapt their working time in response to shifts in their earnings profiles. This seems reasonable as employees are severely constrained in their working time choices. It should be noted, that this elasticity does not make any statements about movements along the earnings profiles, given the static nature of the labor supply model.
} 
Table 6: Responses in main job working hours and leisure

\begin{tabular}{|c|c|c|c|c|c|c|c|}
\hline & \multirow{3}{*}{ Dependent variables } & \multirow{2}{*}{\multicolumn{3}{|c|}{ Log of main job hours }} & (4) & (5) & (6) \\
\hline & & & & & \multicolumn{3}{|c|}{ Log of leisure hours } \\
\hline & & $\mathrm{FE}$ & $\mathrm{FE}$ & FE & FE & $\mathrm{FE}$ & FE \\
\hline \multirow[t]{7}{*}{$\begin{array}{l}\text { Without job and wealth } \\
\text { controls }\end{array}$} & Wage shock & $\begin{array}{l}-0.047^{*} \\
(0.026)\end{array}$ & & & $\begin{array}{c}-0.055^{* *} \\
(0.023)\end{array}$ & & \\
\hline & Shock intensity & & $\begin{array}{l}-0.002 \\
(0.003)\end{array}$ & & & $\begin{array}{l}-0.004 \\
(0.003)\end{array}$ & \\
\hline & Repayment & & & $\begin{array}{c}-0.123 \\
(0.157)\end{array}$ & & & $\begin{array}{c}0.026 \\
(0.137)\end{array}$ \\
\hline & Log of main job hours & & & & $\begin{array}{c}-0.433 * * * \\
(0.021)\end{array}$ & $\begin{array}{c}-0.431 * * * \\
(0.021)\end{array}$ & $\begin{array}{c}-0.431 * * * \\
(0.021)\end{array}$ \\
\hline & LL & 1135.04 & 1132.12 & 1132.45 & 1593.05 & 1589.57 & 1587.27 \\
\hline & R-squared & 0.006 & 0.004 & 0.004 & 0.198 & 0.197 & 0.196 \\
\hline & Implied change in hours & -1.9 & & & -3.4 & & \\
\hline \multirow[t]{10}{*}{ With job and wealth controls } & Wage shock & $\begin{array}{l}-0.047 * \\
(0.026)\end{array}$ & & & $\begin{array}{c}-0.057^{* *} \\
(0.023)\end{array}$ & & \\
\hline & Shock intensity & & $\begin{array}{l}-0.002 \\
(0.003)\end{array}$ & & & $\begin{array}{l}-0.003 \\
(0.003)\end{array}$ & \\
\hline & Repayment & & & $\begin{array}{c}-0.135 \\
(0.157)\end{array}$ & & & $\begin{array}{c}0.013 \\
(0.138)\end{array}$ \\
\hline & Log of main job hours & & & & $\begin{array}{c}-0.477^{* * *} \\
(0.025)\end{array}$ & $\begin{array}{c}-0.472^{* * *} \\
(0.025)\end{array}$ & $\begin{array}{c}-0.471 * * * \\
(0.025)\end{array}$ \\
\hline & Log of hourly wage & $\begin{array}{l}-0.026 \\
(0.054)\end{array}$ & $\begin{array}{l}-0.024 \\
(0.054)\end{array}$ & $\begin{array}{l}-0.023 \\
(0.004)\end{array}$ & $\begin{array}{c}-0.016 * * * \\
(0.005)\end{array}$ & $\begin{array}{c}-0.014 * * * \\
(0.005)\end{array}$ & $\begin{array}{c}-0.014 * * * \\
(0.005)\end{array}$ \\
\hline & LL & 1145.67 & 1142.74 & 1143.22 & 1631.05 & 1625.99 & 1624.75 \\
\hline & R-squared & 0.012 & 0.010 & 0.010 & 0.216 & 0.214 & 0.213 \\
\hline & Implied change in hours & -1.9 & & & -3.6 & & \\
\hline & LR test, Prob > Chi2 (df 18) & 0.000 & 0.000 & 0.000 & 0.000 & 0.000 & 0.000 \\
\hline & Number of observations & 3472 & 3472 & 3472 & 3472 & 3472 & 3472 \\
\hline
\end{tabular}
calculations. 
Table 7: Response time to wage shocks
(1)
(2)
(3)
(4)
(5)
(6)

Dependent variable

Second job holding

\begin{tabular}{lcccccc} 
& $\mathrm{RE}$ & $\mathrm{RE}$ & $\mathrm{RE}$ & $\mathrm{RE}$ & $\mathrm{RE}$ & $\mathrm{RE}$ \\
\hline Current wage shock & $0.023^{* * *}$ & & & $0.024^{* * *}$ & & \\
& $(0.009)$ & & & $(0.009)$ & & \\
Shock 3-6 months ago & & $\begin{array}{c}0.039^{* * *} \\
(0.013)\end{array}$ & & & $(0.014)$ & \\
& & & 0.026 & & & 0.023 \\
Shock 9-12 months ago & & & $(0.017)$ & & & $(0.017)$ \\
& 12.25 & 14.41 & 14.75 & 20.42 & 22.05 & 22.33 \\
Hausman test, chi2 & 10 & 10 & 10 & 26 & 26 & 26 \\
df & 0.351 & 0.349 & 0.350 & 0.350 & 0.348 & 0.349 \\
Rho & 39.63 & 40.93 & 34.62 & 67.32 & 68.24 & 61.98 \\
Chi2 of model & 0.014 & 0.015 & 0.013 & 0.023 & 0.024 & 0.022 \\
R-squared & 3472 & 3472 & 3472 & 3472 & 3472 & 3472 \\
Observations & & & & & & \\
\hline
\end{tabular}

\section{Dependent variable}

Subsidiary farming job

\begin{tabular}{lcccccc} 
& $\mathrm{RE}$ & $\mathrm{RE}$ & $\mathrm{RE}$ & $\mathrm{RE}$ & $\mathrm{RE}$ & $\mathrm{RE}$ \\
\hline Current wage shock & $0.035^{\dagger}$ & & & 0.033 & & \\
Shock 3-6 months ago & $(0.023)$ & & & $(0.025)$ & & $0.061^{* *}$ \\
& & $\begin{array}{c}0.063^{* *} \\
(0.030)\end{array}$ & & & $(0.030)$ & \\
Shock 9-12 months ago & & & 0.052 & & & 0.050 \\
& & & $(0.037)$ & & & $(0.038)$ \\
Hausman test, chi2 & 3.09 & 3.32 & 2.70 & 22.87 & 21.84 & 21.11 \\
df & 6 & 6 & 6 & 18 & 18 & 18 \\
Rho & 0.401 & 0.400 & 0.400 & 0.403 & 0.402 & 0.402 \\
Chi2 of model & 199.2 & 198.8 & 197.9 & 16748 & 16647 & 16563 \\
R-squared & 0.130 & 0.130 & 0.130 & 0.133 & 0.134 & 0.133 \\
Observations & 1834 & 1834 & 1834 & 1834 & 1834 & 1834 \\
\hline Demographic controls & $\mathrm{X}$ & $\mathrm{X}$ & $\mathrm{X}$ & $\mathrm{X}$ & $\mathrm{X}$ & $\mathrm{X}$ \\
Job \& wealth controls & - & - & - & $\mathrm{X}$ & $\mathrm{X}$ & $\mathrm{X}$ \\
\hline
\end{tabular}

Note: Due to smaller sample size in the subsidiary farming model, some variables were removed from the model (place dummies, firm ownership). Critical value for $d f(6)$ : 12.6, $d f(10)$ : 18.3, $d f(18): 28.9$ and for $d f(26)$ : 38.9 at the $5 \%$ significance level. Robust standard errors clustered by id in parentheses. Hausman test is performed on unclustered data; ${ }^{* *} \mathrm{p}<0.01,{ }^{* *} \mathrm{p}<0.05,{ }^{*} \mathrm{p}<0.1,{ }^{\dagger} \mathrm{p}<0.15$. Source: ULMS, own calculations. 


\subsection{Instrumental Variable Estimation}

Previous results have shown that the incidence of a wage shock increases the propensity to hold a secondary activity and the working hours therein. These results might be confounded by measurement error in the right hand side variable thus attenuating the estimated coefficient of interest. The relevant coefficient will then appear closer to zero than the true estimate. To solve the potential bias from measurement error in the shock variable an instrumental variable approach is applied. Table 8 and Table 9 show instrumental variable estimates for both the extensive and intensive margin (the full first stage can be found in Table A8). The participation equation and hour equation are both estimated with a random effects G2SLS model. In all cases except one, the Hausman test indicates a preference for the more efficient random effects model.

To condense information, the table provides only the estimates of interest. The RE G2SLS model does not allow producing an F statistics to assess the strength of the instrument directly; however, the $\mathrm{z}$ statistics for the instrumental variable in the first stage are very strong for the second job participation and all hours equations (around 10-11) providing some comfort regarding the predictive power of the instrument. Results for the second stage of the 2SLS suggest that wage shocks have a much bigger impact on the participation decision in a second job than previously found in the OLS or FE models. The previously positive effect on subsidiary farming, however, disappears in the IV approach. Unfortunately, analyzing the effect of wage shocks in regional subsamples reduces the suitability of the instrument as it builds on the regional variation of wage shocks. When estimated with G2SLS, the effect on working hours becomes much smaller and suggests an increase in second job working time of half an hour. However, it must be noted that in contrast to the Tobit model the G2SLS estimation does not account for censoring in the hours equations. Coefficients can thus not be directly compared. Table A3 reproduces a standard linear fixed-effects estimation of second job working hours; its coefficients are the appropriate basis for comparison. The previous estimates of 0.2 rose by around 170 to 190 percent when correcting the bias from measurement error. In the subsidiary farming hours equation-which suffers only very little from censoring - the estimates become more than twice as large after correcting for measurement error. A wage shock thus induces an increase of almost 10 hours of working time on the land plot. With the exception of the subsidiary farming participation equation all instrumental variable estimates confirm the presence of measurement error so that previous estimates in the participation and working time decisions were biased towards zero. 
Table 8: G2SLS estimates of secondary activities
(1)
(2)
(3)
(4)
(5)
(6)

Dependent variable

Second job holding

Subsidiary farming

\begin{tabular}{|c|c|c|c|c|c|c|}
\hline & $\mathrm{RE}$ & $\mathrm{RE}$ & $\mathrm{RE}$ & $\mathrm{RE}$ & $\mathrm{RE}$ & $\mathrm{RE}$ \\
\hline Wage shock & $\begin{array}{c}0.127 * * * \\
(0.046)\end{array}$ & $\begin{array}{c}0.123^{* * *} \\
(0.046)\end{array}$ & & & $\begin{array}{l}-0.028 \\
(0.146)\end{array}$ & $\begin{array}{l}-0.026 \\
(0.164)\end{array}$ \\
\hline Wage shock intensity & & & $\begin{array}{c}0.032 * * \\
(0.015)\end{array}$ & $\begin{array}{c}0.031^{* *} \\
(0.014)\end{array}$ & & \\
\hline Log hours main job & & $\begin{array}{l}-0.012 \\
(0.010)\end{array}$ & & $\begin{array}{l}-0.007 \\
(0.013)\end{array}$ & & $\begin{array}{l}-0.029 \\
(0.032)\end{array}$ \\
\hline Log non-labor income & & $\begin{array}{c}0.006^{* * *} \\
(0.002)\end{array}$ & & $\begin{array}{c}0.005^{* * *} \\
(0.002)\end{array}$ & & $\begin{array}{l}-0.004 \\
(0.005)\end{array}$ \\
\hline Hourly wage main job & & $\begin{array}{l}0.004^{*} \\
(0.002)\end{array}$ & & $\begin{array}{c}0.003 \\
(0.002)\end{array}$ & & $\begin{array}{l}-0.006 \\
(0.010)\end{array}$ \\
\hline Second job hourly wage & & $\begin{array}{c}0.001^{* * *} \\
(0.000)\end{array}$ & & $\begin{array}{l}0.001^{* *} \\
(0.000)\end{array}$ & & NA \\
\hline First stage (Dep. variable & : wage shoch & & & & & \\
\hline $\begin{array}{l}\text { Wage shock risk } \\
\text { (sector, region) }\end{array}$ & $\begin{array}{c}0.874^{* * * *} \\
(0.077)\end{array}$ & $\begin{array}{c}0.868 * * * \\
(0.076)\end{array}$ & $\begin{array}{c}3.390 * * * \\
(0.705)\end{array}$ & $\begin{array}{c}3.402 * * * \\
(0.702)\end{array}$ & $\begin{array}{c}1.014 * * * \\
(0.133)\end{array}$ & $\begin{array}{c}0.907 * * * \\
(0.131)\end{array}$ \\
\hline z-stats & 11.16 & 11.38 & 4.81 & 4.85 & 7.60 & 6.90 \\
\hline Female & $\begin{array}{l}-0.013 \\
(0.011)\end{array}$ & $\begin{array}{c}-0.042^{* * *} \\
(0.011)\end{array}$ & $\begin{array}{c}0.007 \\
(0.106)\end{array}$ & $\begin{array}{l}-0.096 \\
(0.107)\end{array}$ & $\begin{array}{l}-0.018 \\
(0.019)\end{array}$ & $\begin{array}{c}-0.067 * * * \\
(0.020)\end{array}$ \\
\hline Age & $\begin{array}{c}0.011 * * * \\
(0.004)\end{array}$ & $\begin{array}{c}0.014^{* * *} \\
(0.004)\end{array}$ & $\begin{array}{l}-0.004 \\
(0.036)\end{array}$ & $\begin{array}{c}0.011 \\
(0.036)\end{array}$ & $\begin{array}{c}0.007 \\
(0.007)\end{array}$ & $\begin{array}{l}0.011^{*} \\
(0.007)\end{array}$ \\
\hline Age squared/100 & $\begin{array}{c}-0.018^{* * * *} \\
(0.005)\end{array}$ & $\begin{array}{c}-0.022^{* * * *} \\
(0.005)\end{array}$ & $\begin{array}{l}-0.003 \\
(0.046)\end{array}$ & $\begin{array}{l}-0.020 \\
(0.046)\end{array}$ & $\begin{array}{l}-0.013 \\
(0.009)\end{array}$ & $\begin{array}{c}-0.018^{* *} \\
(0.009)\end{array}$ \\
\hline Years of education & $\begin{array}{c}0.002 \\
(0.002)\end{array}$ & $\begin{array}{c}0.008^{* * *} \\
(0.003)\end{array}$ & $\begin{array}{c}0.013 \\
(0.022)\end{array}$ & $\begin{array}{c}0.032 \\
(0.022)\end{array}$ & $\begin{array}{c}0.000 \\
(0.004)\end{array}$ & $\begin{array}{c}0.006 \\
(0.004)\end{array}$ \\
\hline $\begin{array}{l}\text { Log of working hours } \\
\text { main job }\end{array}$ & & $\begin{array}{c}-0.082 * * * \\
(0.017)\end{array}$ & & $\begin{array}{c}-0.546^{* * * *} \\
(0.141)\end{array}$ & & $\begin{array}{c}-0.106 * * * \\
(0.024)\end{array}$ \\
\hline Demographic controls & $\mathrm{X}$ & $\mathrm{X}$ & $\mathrm{X}$ & $\mathrm{X}$ & $\mathrm{X}$ & $\mathrm{X}$ \\
\hline Wealth controls & - & $\mathrm{X}$ & - & $\mathrm{X}$ & - & $\mathrm{X}$ \\
\hline Hausman test, chi2 & 0.56 & 0.46 & 32.55 & 18.44 & 10.20 & 12.97 \\
\hline df & 13 & 17 & 13 & 17 & 11 & 15 \\
\hline R-squared & 0.010 & 0.013 & 0.011 & 0.012 & 0.146 & 0.147 \\
\hline Observations & 3472 & 3472 & 3472 & 3472 & 1834 & 1834 \\
\hline
\end{tabular}

Note: For full first stage results of (1) and (2) see Table A8. The regressions for the Hausman test were specified without time-invariant variables. The smallest critical value is for $d f(11): 19.7$ at the $5 \%$ significance level. The critical value for $d f(13)$ : 22.3 at the 5\% significance level. Detailed region fixed effects and job characteristics are not controlled for, as they are measurement units for the shock instrument. Standard errors in parentheses; ${ }^{* * *} \mathrm{p}<0.01,{ }^{* *} \mathrm{p}<0.05,{ }^{*} \mathrm{p}<0.1$. Source: ULMS, own calculations. 
Table 9: G2SLS estimates of hours in secondary activities

(1) (2) (3) (4)

Dependent variable

Hours in second job

Hours in subsidiary farming

\begin{tabular}{|c|c|c|c|c|}
\hline & $\mathrm{RE}$ & $\mathrm{RE}$ & $\mathrm{RE}$ & $\mathrm{RE}$ \\
\hline Wage shock & $\begin{array}{c}0.551^{* *} \\
(0.268)\end{array}$ & $\begin{array}{c}0.526 * * \\
(0.267)\end{array}$ & $\begin{array}{c}9.942^{* *} \\
(4.156)\end{array}$ & $\begin{array}{c}9.445^{* *} \\
(4.649)\end{array}$ \\
\hline Log hours main job & & $\begin{array}{l}-0.081 \\
(0.057\end{array}$ & & $\begin{array}{c}-0.185 * * * \\
(0.035)\end{array}$ \\
\hline Log non-labor income & & $\begin{array}{c}0.028 * * * \\
(0.009)\end{array}$ & & $\begin{array}{c}0.085 \\
(0.224)\end{array}$ \\
\hline Hourly wage main job & & $\begin{array}{c}-0.005 \\
(0.013)\end{array}$ & & $\begin{array}{l}-0.487 \\
(0.367)\end{array}$ \\
\hline Second job hourly shadow wage & & $\begin{array}{c}0.002 \\
(0.002)\end{array}$ & & \\
\hline \multicolumn{5}{|c|}{ First stage (Dep. variable: wage shock) } \\
\hline Wage shock risk (sector, region) & $\begin{array}{c}0.861 * * * \\
(0.077)\end{array}$ & $\begin{array}{c}0.868 * * * \\
(0.076)\end{array}$ & $\begin{array}{c}1.350 * * * \\
(0.134)\end{array}$ & $\begin{array}{c}1.212^{* * *} \\
(0.133)\end{array}$ \\
\hline z-value of instrument & 11.16 & 11.38 & 10.11 & 9.14 \\
\hline Female & $\begin{array}{l}-0.013 \\
(0.011)\end{array}$ & $\begin{array}{c}-0.042 * * * \\
(0.011)\end{array}$ & $\begin{array}{c}0.007 \\
(0.019)\end{array}$ & $\begin{array}{c}-0.046^{* *} \\
(0.020)\end{array}$ \\
\hline Age & $\begin{array}{c}0.011^{* * *} \\
(0.004)\end{array}$ & $\begin{array}{c}0.014 * * * \\
(0.004)\end{array}$ & $\begin{array}{l}0.012^{*} \\
(0.007)\end{array}$ & $\begin{array}{c}0.016^{* *} \\
(0.007)\end{array}$ \\
\hline Age squared/100 & $\begin{array}{c}-0.018 * * * \\
(0.005)\end{array}$ & $\begin{array}{c}-0.022 * * * \\
(0.005)\end{array}$ & $\begin{array}{c}-0.022^{* *} \\
(0.009)\end{array}$ & $\begin{array}{c}-0.025 * * * \\
(0.009)\end{array}$ \\
\hline Years of education & $\begin{array}{c}0.002 \\
(0.002)\end{array}$ & $\begin{array}{c}0.008 * * * \\
(0.003)\end{array}$ & $\begin{array}{l}-0.002 \\
(0.004)\end{array}$ & $\begin{array}{c}0.005 \\
(0.005)\end{array}$ \\
\hline Log of working hours main job & & $\begin{array}{c}-0.082^{* * *} \\
(0.017) \\
\end{array}$ & & $\begin{array}{c}-0.002^{* *} \\
(0.001) \\
\end{array}$ \\
\hline Demographic controls & $\mathrm{X}$ & $\mathrm{X}$ & $\mathrm{X}$ & $\mathrm{X}$ \\
\hline Wealth controls & - & $\mathrm{X}$ & - & $\mathrm{X}$ \\
\hline Hausman test, chi2 & 3.05 & 11.50 & 2.71 & 2.57 \\
\hline df & 13 & 17 & 11 & 15 \\
\hline R-squared & 0.010 & 0.013 & 0.106 & 0.129 \\
\hline Observations & 3472 & 3472 & 1352 & 1352 \\
\hline
\end{tabular}

Note: Models (1) and (2) treat censored values as uncensored. The sample of models (3) and (4) comprises only employees in towns and villages who were engaged in subsidiary farming in both years. For the full first stage results see Table A8. Due to smaller sample size in the subsidiary farming model, some variables were removed from the model (place dummies, firm ownership). The regressions for the Hausman test were specified without time-invariant variables. The smallest critical value is for $d f(11)$ : 19.7 at the $5 \%$ significance level. Detailed region fixed effects and job characteristics are not controlled for, as they are measurement units for the shock instrument. Standard errors in parentheses; ${ }^{* * *} \mathrm{p}<0.01,{ }^{* *} \mathrm{p}<0.05$, ${ }^{*} \mathrm{p}<0.1$. Source: ULMS, own calculations. 


\subsection{Wage Shocks and Quitting Behavior}

If workers were generally risk averse, they would always prefer to work in jobs with lower wage uncertainty. Hence, after being affected by wage arrears once, they might be inclined to change jobs. As noted by Earle and Sabirianova (2002) the nature of wage arrears exerts a bonding effect, as leaving the firm might reduce the probability of being paid the full amount of outstanding wages. The resulting trade-off between quitting and staying is an empirical question. The availability of second jobs adds a twist to the quitting decision: When faced with wage non-payment workers might prefer to search for second jobs first and quit the main job as soon the second job can be turned into regular (full time) employment. Unfortunately, the data do not permit the exact tracking of each specific employee-employer relationship. Yet, this stepping stone hypothesis can be investigated by analyzing differences in exit patterns of workers with and without wage shocks and workers who hold a second job or not. The overall fraction of job changers between the 2003 and 2004 waves is 8.9 percent. As the share of employees who switch job within one year is slightly higher among those who currently suffer from wage arrears (10.1 percent), job quitting might dominate the bonding effect; however, the difference is quite small. ${ }^{32}$ Table 10 estimates the conditional impact of current wage arrears on the propensity to change job within one year. The coefficients on both, wage shock indicator and wage intensity are positive-but only weakly significant. Neither second job holdings themselves, nor the holding of a second job conditional on suffering from a wage shock are significantly correlated to a job change in the future. This implies that second jobs are not per se used as stepping stones towards new employment by employees with risky job remuneration. Still, the coefficient on the interaction term between shock intensity and second job holdings (column 4) is highly significant indicating that workers with second jobs start leaving their main job as arrears accumulate.

\footnotetext{
${ }^{32}$ It should be noted, that involuntary job separation rates are quite low in most transition countries (Brown and Earle, 2003). While Lehmann, Pignatti and Wadsworth (2006) find relatively high overall seperation rates for Ukraine, the share of involuntary layoffs is again modest. Also, self-employment is still very rare in Ukraine. The shares of entrepreneurial activities are higher in urban areas (2.8 percent) than in rural areas (2.4 percent), while more persons enter self-employment between 2003 and 2004 in rural areas (2.2 percent) than in urban areas ( 0.7 percent).
} 
Table 10: Wage shocks and job change

\section{Dependent variable}

Job change between $t$ and $t+1$

Probit

$0.034 *$

$(0.022)$

Intensity of wage shocks in $t$

Second job holding

Wage shock/intensity*second job holding

Demographic controls

Job \& wealth controls

Pseudo R-squared

Observations

Probit

$0.033^{*}$

Probit

Probit

$0.003 * * \quad 0.001$

$(0.001) \quad(0.001)$

0.036

$(0.144)$

$\mathrm{X}$

$\mathrm{X}$

$\mathrm{X}$

0.158

1736
0.025

$0.025^{* * *}$

(0.007)

$\mathrm{X}$

$\mathrm{X}$

0.189

1736
$\mathrm{X}$

0.188

1736

Note: Marginal fixed effects reported. The interaction term in column (2) is with wage shock, the one in column (4) with wage shock intensity. The estimation adopts a forward looking linear probability model. Robust standard errors in parentheses; ${ }^{* * *} \mathrm{p}<0.01,{ }^{* *} \mathrm{p}<0.05,{ }^{*} \mathrm{p}<0.1$. Source: ULMS, own calculations.

\subsection{Consumption Smoothing}

The smoothing model (equation 4) tests whether households whose members suffer from a wage shock (at least one household member) consume less and whether they successfully use secondary activities in order to smooth out these shortfalls (Table 11). The coefficients on income indicate that consumption is co-moving with income, however, only partially. The fact that the estimates are statistically different from zero but smaller than one implies that consumption is positively related to current income but far from being perfectly insurable against income fluctuations. Wage shocks within the household induce on average a 3 percent shortfall in household consumption, while second jobs per se do not significantly affect consumption levels. As our outcome variable measures the log of total household consumption, the fixed effect regressions also account for household size. Column (2) adds an interaction term of wage arrear incidence with second job holdings. The coefficient thus measures how consumption levels are affected in households that make use of second job holdings in order to cope with wage shocks. The table shows a highly significant positive coefficient; however, to study the effect of interest, the relevant measure is the joint coefficient of $\delta_{2}+\delta_{3}+\delta_{4}$, which is reported at the bottom of the table. The hypothesis (H0) under consideration is that households coping with second jobs cannot smooth out consumption shortfalls from wage shocks, so $\delta_{2}+\delta_{3}+\delta_{4}<0$. 
Table 11: Secondary activities as household consumption smoothing mechanisms
(1)
(2)
(3)
(4)
(5)
(6)
(7)
(8)

\begin{tabular}{|c|c|c|c|c|c|c|c|c|}
\hline \multirow[t]{2}{*}{ Dependent variable } & Full sample & Full sample & Rural sample & $\begin{array}{l}\text { Urban sample } \\
\text { Log of househol }\end{array}$ & $\begin{array}{l}\text { Full sample } \\
\text { consumption }\end{array}$ & Rural sample & Urban sample & Full sample \\
\hline & FE & $\mathrm{FE}$ & FE & $\mathrm{FE}$ & FE & $\mathrm{FE}$ & $\mathrm{FE}$ & FE \\
\hline \multirow[t]{2}{*}{ Log of income } & $0.121 * * *$ & $0.120 * * *$ & $0.123 * * *$ & $0.118 * * *$ & $0.119 * * *$ & $0.122 * * *$ & $0.118 * * *$ & $0.119 * * *$ \\
\hline & $(0.007)$ & $(0.007)$ & $(0.009)$ & $(0.010)$ & $(0.007)$ & $(0.009)$ & $(0.010)$ & $(0.007)$ \\
\hline \multirow{2}{*}{ Wage arrear in $\mathrm{HH}\left(\delta_{2}\right)$} & $-0.029 * *$ & $-0.040 * *$ & -0.034 & -0.045 & $-0.054^{* *}$ & $-0.053^{*}$ & -0.044 & $-0.059 * * *$ \\
\hline & $(0.012)$ & $(0.020)$ & $(0.024)$ & $(0.040)$ & $(0.022)$ & $(0.027)$ & $(0.040)$ & $(0.022)$ \\
\hline \multirow{2}{*}{ Second job in $\mathrm{HH}\left(\delta_{3}\right)$} & -0.024 & $-0.045^{* *}$ & -0.049 & -0.033 & & & & $-0.047 * *$ \\
\hline & $(0.021)$ & $(0.023)$ & $(0.033)$ & $(0.031)$ & & & & $(0.023)$ \\
\hline \multirow{2}{*}{ Arrear*Second job $\left(\delta_{4}\right)$} & & $0.099 * *$ & 0.089 & $0.132 *$ & & & & $0.102 * *$ \\
\hline & & $(0.043)$ & $(0.056)$ & $(0.068)$ & & & & $(0.043)$ \\
\hline \multirow{2}{*}{$\begin{array}{l}\text { Arrear*Increase in sub- } \\
\text { sidiary farming hours }\left(\delta_{5}\right)\end{array}$} & & & & & $0.049 * *$ & $0.055^{*}$ & 0.043 & $0.052 * *$ \\
\hline & & & & & $(0.025)$ & $(0.031)$ & $(0.047)$ & $(0.025)$ \\
\hline \multirow[t]{2}{*}{ Access to credit } & & 0.418 & $1.516 *$ & -3.196 & 0.428 & $1.512 *$ & -3.209 & 0.445 \\
\hline & & $(0.485)$ & $(0.817)$ & $(2.327)$ & $(0.485)$ & $(0.817)$ & $(2.330)$ & $(0.485)$ \\
\hline \multirow[t]{2}{*}{ Arrear*Access credit } & & 0.046 & -0.098 & 0.075 & 0.078 & -0.099 & 0.070 & 0.035 \\
\hline & & $(0.234)$ & $(0.323)$ & $(0.384)$ & $(0.233)$ & $(0.318)$ & $(0.385)$ & $(0.234)$ \\
\hline \multirow[t]{2}{*}{ Town } & & $0.102 * *$ & $0.158 * * *$ & & $0.106 * *$ & $0.159 * * *$ & & $0.106 * *$ \\
\hline & & $(0.044)$ & $(0.056)$ & & $(0.044)$ & $(0.056)$ & & $(0.044)$ \\
\hline \multirow[t]{2}{*}{ Large city } & & $0.134 * * *$ & & & $0.139 * * *$ & & & $0.139 * * *$ \\
\hline & & $(0.046)$ & & & $(0.046)$ & & & $(0.046)$ \\
\hline \multirow[t]{2}{*}{ Household size } & $0.082 * * *$ & $0.082 * * *$ & $0.083^{* * *}$ & $0.075 * * *$ & $0.082 * * *$ & $0.083^{* * *}$ & $0.075^{* * *}$ & $0.082 * * *$ \\
\hline & $(0.006)$ & $(0.006)$ & $(0.008)$ & $(0.009)$ & $(0.006)$ & $(0.008)$ & $(0.009)$ & $(0.006)$ \\
\hline \multirow[t]{2}{*}{ Constant } & $5.423 * * *$ & $5.320 * * *$ & $5.243 * * *$ & $5.746 * * *$ & $5.320 * * *$ & $5.247 * * *$ & $5.742 * * *$ & $5.319 * * *$ \\
\hline & $(0.047)$ & $(0.063)$ & $(0.086)$ & $(0.189)$ & $(0.063)$ & $(0.086)$ & $(0.189)$ & $(0.063)$ \\
\hline (2)-(4): $\delta_{2}+\delta_{3}+\delta_{4}$ & & 0.014 & 0.044 & -0.032 & -0.005 & 0.001 & -0.001 & 0.049 \\
\hline (5)-(7): $\delta_{2}+\delta_{3}+\delta_{5}$ & & $(0.044)$ & $(0.054)$ & $(0.076)$ & $(0.026)$ & $(0.031)$ & $(0.055)$ & $(0.047)$ \\
\hline (8): $\delta_{2}+\delta_{3}+\delta_{4}+\delta_{5}$ & & & & & & & & \\
\hline Hausman test, chi2 & 74.00 & 117.79 & 51.87 & 38.24 & 90.05 & 86.46 & 19.75 & 109.38 \\
\hline R-squared & 0.219 & 0.224 & 0.235 & 0.212 & 0.223 & 0.235 & 0.209 & 0.226 \\
\hline Observations & 4270 & 4270 & 2222 & 1886 & 4270 & 2222 & 1886 & 4270 \\
\hline
\end{tabular}

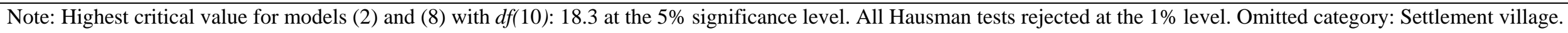

Standard errors in parentheses; ${ }^{* * *} \mathrm{p}<0.01,{ }^{* *} \mathrm{p}<0.05,{ }^{*} \mathrm{p}<0.1$. Source: ULMS, own calculations. 
Although $\delta_{2}+\delta_{3}+\delta_{4}$ are jointly positive, they are not statistically significant different from zero. In other words, household suffering from a wage shock and using second jobs to cope with them are no worse off than households without any wage shock. Column 2 also accounts for access to the credit market which might be considered a tool for consumption smoothing in developed economies. As expected in a setting of credit constraints, the financial market plays no significant role in consumption determination and is not used as a consumption smoothing tool. Columns 3 and 4 show results after splitting the sample into rural and urban households. While second jobs seem to be a significant coping strategy for urban households, they are marginally insignificant in rural areas. Overall, the joint coping term is positive for rural areas and negative for urban areas, but the large standard errors leave the effects insignificant. Rural households might use other coping strategies which buffer their consumption levels against unforeseen shortfalls, like subsidiary farming. In columns 5 to 7 , an interaction term between the incidence of current wage shocks and a dummy indicating an increase of subsidiary farming hours is added to the model. This is done as the previous analysis suggested more pronounced reactions at the intensive rather than extensive margin of subsidiary farming. Indeed, rural households can significantly improve their welfare situation by extending their farming activities, while this option seems less helpful fur urban residents. The overall results suggest that farming is a successful coping strategy for consumption smoothing in rural areas while second jobs are better suitable for urban areas. Rural labor markets with their low dynamics seem incapable of absorbing transitory excess labor supply. Column 8 includes both coping strategies at the same time into the consumption smoothing model. All previous results remain robust.

In order to test the sensitivity of the results with respect to household size, Table A9 in the Appendix replicates all results with adult equivalence scales. Such scales account for economies of scales in household consumption. Oxford equivalence scales assign the consumption weight of one to the first adult, 0.7 to all additional adults and 0.5 to all children (aged up to 15) in the household. Applying this consumption correction does not change any of the previous results.

\section{Robustness and Alternative Hypotheses}

The following section evaluates potential alternative hypotheses which might explain the observed labor supply patterns and hence pose a threat to the validity of the identified results. In detail, the following section shows that the labor supply response in coping 
activities cannot be explained by constrained working hours or by anticipatory ex-ante coping.

\subsection{Constrained Working Hours Hypothesis}

One alternative explanation for the observed pattern of secondary activities refers to the initial idea of second job holding models. The early literature analyzed second job holdings in the USA, focusing mainly on constraints in working hours. These early model applications were not associated with the consumption smoothing motive. Is it then possible that second job holdings were merely driven by hours constraints? Some facts point into this direction: Employees in Ukraine face a limited choice set of working hours. The Ukrainian Labor Code stemming from the 1970s is restrictive with respect to contractual flexibility and prescribes a weekly working time of 40 hours. Consequently, almost all employees are contracted for exactly 40 hours. More flexible job contracts are starting to emerge slowly. Only 4.4 percent of employees usually work less than full time. ${ }^{33}$ In our context, problems would arise if enterprises that imposed wage arrears on their employees were at the same time reducing labor demand. This might be plausible if wage arrears reflected negative demand shocks to firms causing a simultaneous reduction of production and labor costs. In the reference week, less than 1.6 percent of all employees report that they have worked fewer than usual hours because they were either involuntarily sent home, because of work schedule or because demand or input supply was too low. However, to check whether these groups of workers might be more likely to take on a second job, the participation and hours regressions are re-run with interactions of the wage arrear indicator and two dummies, one indicating that a person is working fewer hours for demand reasons, the other one indicating involuntary leaves from work (Table 12). Neither the variable indicating low demand nor the interaction term has any impact on second job holdings. The compulsory leave dummy shows a positive sign in the working hours model, suggesting that workers from firms that sent (part of) their workforce home work on average two hours more in a second job. Less clear is the picture for

\footnotetext{
${ }^{33}$ Additional 9.8 percent of employees report less than 40 hours work per week, but claim to be considered fulltime workers as their contractual work load is lower than 40 hours. This applies in specific, often hazardous, occupations, for night work and for employees aged up to 18 years. The latter group, however, is excluded from the sample. As a robustness check, regressions for part-time and full-time subsamples are run separately. Parttime employment is defined as having worked at most 35 hours per week in 2003. The results are qualitatively the same, with part-time workers being slightly more likely to hold a second job (albeit with imprecise point estimate owing to the small part-time sample). Part- and full-time workers show a similar response to wage arrears (Table A10). This is not surprising, given that main job working hours are controlled for in the standard analysis.
} 
subsidiary farming: While low labor demand plays no role for the amount of hours supplied on land plots, general participation in farming is higher among employees in firms with low demand but no wage shocks. ${ }^{34}$ To further investigate the hypothesis of constrained working hours, contractual and actual hours of work are compared instead of self-reported absence from work. When interacting the wage shock indicator with a dummy variable that takes on the value of one if an employee simultaneously works less than contractual and suffers from a wage arrear (and zero otherwise) the previous results are robust. A final check uses information on desired working hours among those who were reporting less than forty hours in the reference week. ${ }^{35}$ If under normal circumstances time constraints limited these employees, one would expect them to respond with a desired labor supply of more than forty hours. However, 91 percent of those working less than forty hours in the reference week would like to work up to forty hours only. Among those suffering from wage arrears, the share of those wanting to work more than 40 hours is even lower (6.7 percent) and this group is no more likely to hold a second job. Reduced working time alone cannot explain the switch towards second job holdings. This leads to the conclusion that wage shocks have a negative impact on main job hours through the shift towards second job holdings, not vice versa. Employees thus substitute away effort from the risky main job towards the second job.

\subsection{Anticipation of Wage Shocks}

If wage shocks are more likely to appear in some firms or sectors than in others, workers might observe these differences and sort into sectors or firms according to their risk aversion. However, workers employed in at-risk jobs or occupations should be aware of the risk they face and, hence, ex-ante respond to their potential wage shortfalls with precautionary behavior (cp. Low et al., 2010). In that case, the measured labor supply effect might reflect the anticipatory behavior of at-risk workers rather than ex-post coping strategies. To test the anticipation hypothesis a model is estimated whether workers who will suffer from shocks in period $t+1$ already adapt their labor supply in period $t$. The coefficients of the forward looking regressions are shown in Table 13.

\footnotetext{
${ }^{34}$ There are too few observations for involuntary leaves in towns, so that columns (3) and (6) are not replicated for subsidiary farming jobs.

${ }^{35}$ The question on desired working hours is only asked to individuals who work fewer than 40 hours in the reference week.
} 
Table 12: Response to wage shocks in firms with low labor demand or involuntary leaves
(1)
(2)
(3)
(4)
(5)
(6)
(7)
(8)
(9)
(10)

\begin{tabular}{|c|c|c|c|c|c|c|c|c|c|c|}
\hline \multirow[t]{2}{*}{ Dependent variables } & \multicolumn{2}{|c|}{ Second job holding } & \multicolumn{3}{|c|}{ Hrs. in second job } & \multicolumn{2}{|c|}{ Subsidiary farming } & \multicolumn{3}{|c|}{ Hrs. in subsid. farming } \\
\hline & $\mathrm{FE}$ & FE & $\mathrm{FE}$ & RE Tobit & RE Tobit & RE Tobit & $\mathrm{FE}$ & $\mathrm{FE}$ & RE Tobit & RE Tobit \\
\hline Wage shock & $\begin{array}{c}0.028 * * \\
(0.013)\end{array}$ & $\begin{array}{c}0.026^{* *} \\
(0.013)\end{array}$ & $\begin{array}{c}0.029 * * \\
(0.013)\end{array}$ & $\begin{array}{c}4.758 * * * \\
(1.788)\end{array}$ & $\begin{array}{c}2.639 * * \\
(1.195)\end{array}$ & $\begin{array}{c}3.910 * * * \\
(1.432)\end{array}$ & $\begin{array}{c}0.128 * * \\
(0.064)\end{array}$ & $\begin{array}{c}0.154 * * \\
(0.063)\end{array}$ & $\begin{array}{r}2.391 * * \\
(1.048)\end{array}$ & $\begin{array}{l}2.340 * \\
(1.248)\end{array}$ \\
\hline Low labor demand & & $\begin{array}{l}-0.005 \\
(0.028)\end{array}$ & & & $\begin{array}{l}-1.456 \\
(3.681)\end{array}$ & & & $\begin{array}{l}0.371 * * \\
(0.155)\end{array}$ & & $\begin{array}{c}4.933 \\
(5.336)\end{array}$ \\
\hline $\begin{array}{l}\text { Wage shock*Low labor } \\
\text { demand }\end{array}$ & & $\begin{array}{c}0.108 \\
(0.066)\end{array}$ & & & $\begin{array}{c}6.971 \\
(5.593)\end{array}$ & & & $\begin{array}{l}-0.494^{*} \\
(0.255)\end{array}$ & & $\begin{array}{c}-0.695 \\
(10.602)\end{array}$ \\
\hline Involuntary leave & & & $\begin{array}{l}-0.017 \\
(0.172)\end{array}$ & & & $\begin{array}{l}1.884^{*} \\
(1.015)\end{array}$ & & & & \\
\hline $\begin{array}{l}\text { Wage shock*Involuntary } \\
\text { leave }\end{array}$ & & & $\begin{array}{c}0.010 \\
(0.199)\end{array}$ & & & $\begin{array}{l}-5.094 \\
(180.9)\end{array}$ & & & & \\
\hline Demographic controls & $\mathrm{X}$ & $\mathrm{X}$ & $\mathrm{X}$ & $\mathrm{X}$ & $\mathrm{X}$ & $\mathrm{X}$ & $\mathrm{X}$ & $\mathrm{X}$ & $\mathrm{X}$ & $\mathrm{X}$ \\
\hline Job \& wealth controls & $\mathrm{X}$ & $\mathrm{X}$ & $\mathrm{X}$ & $\mathrm{X}$ & $\mathrm{X}$ & $\mathrm{X}$ & $\mathrm{X}$ & $\mathrm{X}$ & $\mathrm{X}$ & $\mathrm{X}$ \\
\hline Rho & 0.530 & 0.523 & 0.529 & 0.683 & 0.271 & 0.110 & 0.631 & 0.620 & 0.387 & 0.384 \\
\hline LL & 3630.9 & 3630.5 & 3627.8 & -547.9 & -598.6 & -587.7 & 134.6 & 131.8 & -6209 & -6208 \\
\hline R-squared / Chi 2 & 0.015 & 0.015 & 0.016 & 24.33 & 32.63 & 33.76 & 0.115 & 0.110 & 1615 & 1298 \\
\hline Observations & 3472 & 3472 & 3472 & 3472 & 3472 & 3472 & 874 & 874 & 1834 & 1834 \\
\hline
\end{tabular}

Note: The sample for subsidiary farming comprises individuals residing in towns, while sample for hours in subsidiary farming comprise individuals residing in towns or villages. Involuntary leaves were quite rare, so that the estimation of model (3) and (6) was not repeated for subsidiary farming. Standard errors in parentheses; $* * * ~ p<0.01$,

$* * \mathrm{p}<0.05, * \mathrm{p}<0.1$. Source: ULMS, own calculations. 
None of the anticipation coefficients on future wage shocks carries a significant positive sign, implying that precautionary behavior is absent. Column 6 shows a negative anticipation effect on subsidiary farming hours; this counter-intuitive result is only significant at the 10 percent level and might reflect a type I error. These general results are in line with the presumption that the incidence of wage shocks has a random component. Consequently, non-anticipation of shocks supports the choice of a framework with myopically behaving agents.

A related explanation for the detected shock response pattern could be associated with past shock experience. The more distant experience of wage shocks is picked up by the individual fixed effects as a 'common history'. Furthermore, having suffered from wage shocks during the 1990s should not have any impact on today's precautionary behavior as wage shocks then were virtually omnipresent in Ukraine. More recent wage shocks could, however, make the difference: In order to test this hypothesis, a variable indicating the incidence of a wage shock 9 to 12 months ago is included in the models alongside the current wage shock dummy. If recent past wage shocks promoted precautionary second job holdings, this variable should pick up part of the estimated coping effect from the current shock. As can be seen from Table 14, the estimates of labor supply responses to wage shocks are almost identical to previous results after controlling for previous shock experience. At the same time, the coefficient of past shock experience is insignificant. This finding further underlines the fact that second jobs are used as immediate coping mechanisms in response to wage shocks.

In sum, the pattern of secondary activities cannot be explained by the rivaling hypotheses about hours constraints and precautionary coping behavior. In an online appendix to this paper, further robustness tests provide evidence that the estimated effects are not confounded by panel sample attrition (Tables A11a, A11b, A12a, A12b). 
Table 13: Anticipation of wage shocks
(1)
(2)
(3)
(4)
(5)
(6)
(7)

\begin{tabular}{|c|c|c|c|c|c|c|c|c|}
\hline \multirow[b]{2}{*}{ Dependent variable } & \multicolumn{2}{|c|}{ Strict anticipation } & \multicolumn{2}{|c|}{ Broad anticipation } & \multicolumn{2}{|c|}{ Strict anticipation } & \multicolumn{2}{|c|}{ Broad anticipation } \\
\hline & $\begin{array}{c}\text { Second job } \\
\text { in } t\end{array}$ & $\begin{array}{l}\text { Hrs. in 2nd } \\
\text { job in } t\end{array}$ & $\begin{array}{c}\text { Second job } \\
\text { in } t\end{array}$ & $\begin{array}{c}\text { Hrs. in 2nd } \\
\text { job in } t\end{array}$ & $\begin{array}{c}\text { Subsidiary } \\
\text { farming in } t\end{array}$ & $\begin{array}{l}\text { Hrs. in sub. } \\
\text { farm. in } t\end{array}$ & $\begin{array}{c}\text { Subsidiary } \\
\text { farming in } t\end{array}$ & $\begin{array}{c}\text { Hrs. in sub. } \\
\text { farm. in } t\end{array}$ \\
\hline Wage shock in $t+1$ & 0.002 & 0.017 & 0.006 & 0.142 & -0.145 & $-3.598^{*}$ & -0.039 & 0.559 \\
\hline Log hours main job & $\begin{array}{l}(0.017) \\
-0.008 \\
(0.014)\end{array}$ & $\begin{array}{l}(0.086) \\
-0.064 \\
(0.060)\end{array}$ & $\begin{array}{l}(0.011) \\
-0.009 \\
(0.012)\end{array}$ & $\begin{array}{l}(0.136) \\
-0.090 \\
(0.080)\end{array}$ & $\begin{array}{l}(0.111) \\
-0.016 \\
(0.079)\end{array}$ & $\begin{array}{c}(1.986) \\
-0.202 * * * \\
(0.056)\end{array}$ & $\begin{array}{c}(0.069) \\
0.001 \\
(0.057)\end{array}$ & $\begin{array}{c}(1.515) \\
-0.192^{* * *} \\
(0.047)\end{array}$ \\
\hline Demographic, job \& welfare controls & $\mathrm{X}$ & $\mathrm{X}$ & $\mathrm{X}$ & $\mathrm{X}$ & $\mathrm{X}$ & $\mathrm{X}$ & $\mathrm{X}$ & $\mathrm{X}$ \\
\hline R-squared & 0.024 & 0.016 & 0.019 & 0.020 & 0.132 & 0.167 & 0.129 & 0.189 \\
\hline Observations & 1518 & 1518 & 1736 & 1736 & 377 & 775 & 437 & 917 \\
\hline
\end{tabular}

Note: Strict anticipation includes only person who do not suffer from current wage shocks. Broad anticipation includes entire sample. Sample for subsidiary farming comprises individuals residing in towns, while sample for hours in subsidiary farming comprise individuals residing in towns or villages. The estimation adopts a linear probability model. Standard errors in parentheses; ${ }^{* * *} \mathrm{p}<0.01,{ }^{* *} \mathrm{p}<0.05,{ }^{*} \mathrm{p}<0.1$. Source: ULMS, own calculations.

Table 14: Effects of wage shocks when controlling for recent shock experience

\begin{tabular}{|c|c|c|c|c|c|c|c|c|}
\hline \multirow{3}{*}{ Dependent variable } & \multirow{2}{*}{\multicolumn{2}{|c|}{$\begin{array}{l}(1) \\
\text { Second job holding }\end{array}$}} & \multirow{2}{*}{\multicolumn{2}{|c|}{$\begin{array}{l}(3) \\
\text { Hrs. in second job }\end{array}$}} & (5) & $(6)$ & (7) & (8) \\
\hline & & & & & \multicolumn{2}{|c|}{ Subsidiary farming } & \multicolumn{2}{|c|}{ Hrs. in subsidiary farming } \\
\hline & $\mathrm{FE}$ & $\mathrm{FE}$ & RE Tobit & RE Tobit & FE & $\mathrm{FE}$ & RE Tobit & RE Tobit \\
\hline \multirow[t]{2}{*}{ Wage shock } & $0.031 * *$ & $0.029 * *$ & $4.718^{* *}$ & $4.688^{* *}$ & $0.131^{* *}$ & $0.118^{*}$ & $4.217 * * *$ & $2.707 * *$ \\
\hline & $(0.013)$ & $(0.013)$ & (1.984) & (2.037) & $(0.062)$ & $(0.067)$ & (1.277) & $(1.210)$ \\
\hline \multirow[t]{2}{*}{ Past wage shock (9 to 12 months ago) } & -0.015 & -0.014 & 0.696 & 0.680 & -0.022 & -0.036 & -0.244 & -0.290 \\
\hline & $(0.024)$ & $(0.024)$ & (3.420) & (3.338) & $(0.116)$ & $(0.119)$ & $(0.297)$ & $(0.221)$ \\
\hline Demographic controls & $\mathrm{X}$ & $\mathrm{X}$ & $\mathrm{X}$ & $\mathrm{X}$ & $\mathrm{X}$ & $\mathrm{X}$ & $\mathrm{X}$ & $\mathrm{X}$ \\
\hline Job \& welfare controls & - & $\mathrm{X}$ & - & $\mathrm{X}$ & - & $\mathrm{X}$ & - & $\mathrm{X}$ \\
\hline Rho & 0.522 & 0.534 & 0.669 & 0.711 & 0.615 & 0.756 & 0.390 & 0.389 \\
\hline LL & 3611 & 3643 & -552.6 & -532.0 & 96.66 & 110.5 & -6223 & -6208 \\
\hline R-squared / Chi2 & 0.004 & 0.023 & 20.3 & 35.3 & 0.035 & 0.065 & 923.5 & 982.4 \\
\hline Observations & 3472 & 3472 & 3472 & 3472 & 874 & 874 & 1834 & 1834 \\
\hline
\end{tabular}

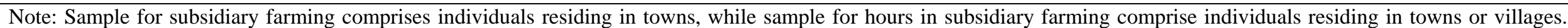
Robust standard errors in parentheses; ${ }^{* * *} \mathrm{p}<0.01,{ }^{* *} \mathrm{p}<0.05$, ${ }^{*} \mathrm{p}<0.1$. Source: ULMS, own calculations. 


\section{Conclusions}

This paper tested whether individuals use secondary activities as consumption smoothing devices against transitory wage shocks, in a setting of myopic and credit constrained agents. The empirical analysis is based on a unique panel data set from Ukraine which provides detailed information on employment relations, wages and wage non-payment. The results suggest a significantly positive albeit small effect of the incidence of wage shocks and shock intensity on second job holdings and a sizeable effect on subsidiary farming in areas with access to land plots. Working hours are increased in second jobs and subsidiary farming by 3 to 5 hours while main job hours and leisure time are reduced in a similar order of magnitude. Exogenous repayment of outstanding wages is used as a supportive quasiexperiment to test the coherence of the temporary coping hypothesis. The data reject several alternative explanations for the observed activity choices, like hours constraints in the main job and the anticipation of shocks.

These findings prove robust when accounting for unobserved heterogeneity of employees by controlling for fixed effects. Most estimates become quantitatively larger after correcting potential measurement error in the shock variable with an instrumental variable approach.

To test the effectiveness of the coping behavior a simple econometric test of household consumption smoothing is carried out. It reveals that non-anticipated transitory wage shocks cannot be perfectly insured ex-ante. However, households whose members cope with wage shocks by re-allocating work effort from main to secondary job manage to keep up their consumption levels. Hence, secondary activities enable households to fully smooth out income shortfalls from wage arrears. The results are in line with the general consumption smoothing literature which suggests that individuals and households put coping mechanisms in place when insurance and foresight are imperfect. The presented evidence is thus consistent with the prediction from the static theory of labor supply.

The findings from this research have several interesting policy implications. First, in the absence of protective social security institutions individuals strive to engage in secondary activities as coping mechanisms in order to reduce the consequences of wage shocks. This evidence indicates that individuals and households might manage to feed themselves; however, politics that rely on this mechanism must keep in mind how limited the scope for self-help might be, e.g. through low demand on the second job market or weather risks. 
Second, the paper has shown how firms' wage payments may lead to diversification on the labor market and thus spill-over from firm policies on labor supply. The results suggest that employees do not entirely retreat from the labor market but on average reduce main employment effort in substitution for secondary activities. Potentially these jobs may be less productive or informal implying negative consequences for tax revenues. Third, the reallocation of work may impact on the regional labor supply, as wage shocks were found to be regionally highly concentrated. The previous research on wage arrears in transition countries has regarded the clustering of wage risks in combination with low job mobility as the main reason why employees refrain from switching employers after shocks. This paper delivers another aspect which has been ignored in the literature so far: If coping mechanisms for consumption smoothing were widely available in the short run, workers might feel less pressure to switch jobs.

\section{Acknowledgment}

I thank Joshua Angrist, Deborah Cobb-Clark, Peter Dolton, Dan Hamermesh, Victor Lavy, Hartmut Lehmann, Jonathan Wadsworth and Natalia Weisshaar as well as seminar and conference participants at Royal Holloway, Amsterdam (EALE), Mannheim (ZEW), Milan (EEA) and Berlin (ESCIRRU) for helpful comments and suggestions The ULMS data were kindly provided by the ESCIRRU consortium and DIW Berlin. The usual disclaimer applies. 


\section{References}

Andrienko, Yuri, and Sergei Guriev. 2004. "Determinants of interregional mobility in Russia.” Economics of Transition 12: 1-27.

Angrist, Joshua D., and Alan B. Krueger. 1999. "Empirical Strategies in Labor Economics.” In Handbook of Labor Economics, ed. Orley Ashenfelter, and David Card, 1463-1555.

Attanasio, Orazio, and Miguel Székely. 2004. "Wage shocks and consumption variability in Mexico during the 1990s.” Journal of Development Economics 73(1): 1-25.

BBC. 2007. http://news.bbc.co.uk/1/hi/uk/6243307.stm

Becker, Gary S. 1965. “A Theory of the Allocation of Time.” Economic Journal 75(229): 493-517.

Block, Michael K. and John M. Heineke. 1973. “The Allocation of Effort Under Uncertainty: The Case of Risk Averse Behavior.” Journal of Political Economy 81(2): 37685.

Blundell, Richard, and Thomas MaCurdy. 1999. "Labor Supply: A Review of Alternative Approaches.” in Handbook of Labor Economics Volume 3A, ed. Orley C. Ashenfelter and David Card, Ch. 27. Amsterdam: Elsevier Science Publishers BV.

Boeri, Tito, and Christopher J. Flinn. 1999. "Returns to Mobility in the Transition to a Market Economy.” Journal of Comparative Economics 27(1): 4-32.

Boyarchuk, Dmytro, Lilia Maliar, and Serguei Maliar. 2005. “The consumption and welfare implications of wage arrears in transition economies." Journal of Comparative Economics 33(3): 540-564.

Brown, J. David, and John S. Earle. 2003. "The Reallocation of Workers and Jobs in Russian Industry: New Evidence on Measures and Determinants.” Economics of Transition 11(2): 221-252.

CFTUU (= Confederation of Free Trade Unions of Ukraine). 2008. "International News Bulletin.” Newsletter 2, Vol. 1, 2.

Cochrane, John H. 1991. “A Simple Test of Consumption Insurance.” Journal of Political Economy 99(5): 957-976.

Cullen, Julie B., and Jonathan Gruber. 2000. "Does unemployment insurance crowd out spousal labor supply?” Journal of Labor Economics 18(3): 546-558 
Desai, Padma, and Todd Idson. 2000. Work without Wages. Russia's Nonpayment Crisis. Cambridge, MA: MIT Press.

Earle, John S., and Klara Z. Sabirianova. 2002. "How late to pay? Understanding wage arrears in Russia.” Journal of Labor Economics 20(3): 661-707.

Earle, John S., and Klara Z. Sabirianova. 2009. “Complementarity and Custom in Wage Contract Violation.” Review of Economics and Statistics 91(4): 832-849.

Earle, John S., Andrew Spicer, and Klara Z. Sabirianova. 2004. "Community Norms and Organizational Practices: The Legitimization of Wage Arrears in Russia, 19921999.” IZA Discussion Paper, IZA Bonn, No. 1006.

Fidrmuc, Jan. 2004. "Migration and regional adjustment to asymmetric shocks in transition economies.” Journal of Comparative Economics 32(2): 230-247.

Gerry, Christopher J., Byung-Yeon Kim, and Carmen A. Li. 2004. “The Gender Wage Gap and Wage Arrears in Russia: Evidence from the RLMS.“ Journal of Population Economics 17(2): 267-288.

Guariglia, Alessandra, and Byung-Yeon Kim. 2003. "Wage arrears uncertainty and precautionary saving in Russia.” Economics of Transition 11(3): 493-512.

Guariglia, Alessandra, and Byung-Yeon Kim. 2006. "The dynamics of moonlighting in Russia. What is happening in the Russian informal economy?” Economics of Transition 14(1): 1-45.

ILO. 1996. “Growing Discontent on Wage Arrears in CIS.” ILO SRO-Budapest Bulletin, 2/96. URL: http://www.ilo.org/public/english/region/eurpro/ budapest/info/bul/962/nl10_11.htm [accessed 10 March 2010]

ILO. 2009. “Global Wage Report.” URL: http://www.ilo.org/wcmsp5/groups/public/--dgreports/---dcomm/documents/publication/wcms_116500.pdf [accessed 15 September 2010].

Jappelli, Tullio, and Luigi Pistaferri. 2006. “Intertemporal Choice and Consumption Mobility.” Journal of the European Economic Association 4(1): 75-115.

Kurkalova, Lyubov A., and Helen H. Jensen. 2000. "Relative Growth of Subsidiary Farming in Post-Soviet Economies: A Labor Supply Story.” Center for Agricultural and Rural Development, Iowa State University, WP 249.

Lehmann, Hartmut, Norberto Pignatti, and Jonathan Wadsworth. 2006. "The incidence and cost of job loss in the Ukrainian labor market.” Journal of Comparative Economics 34(2): 248-271. 
Lehmann, Hartmut, and Katherine Terrell. 2006. “The Ukrainian Labor Market in Transition: Evidence from a New Panel Data Set.” Journal of Comparative Economics, 34(2): 195-199.

Lehmann, Hartmut, Jonathan Wadsworth, and Alessandro Acquisti. 1999. "Crime and Punishment: Job Insecurity and Wage Arrears in the Russian Federation.” Journal of Comparative Economics 27(4): 595-617.

Low, Hamish, Costas Meghir, and Luigi Pistaferri. 2010. "Wage risk and employment risk over the life cycle.” American Economic Review 100(4): 1432-1467.

Lundberg, Shelly. 1985: “The Added Worker Effect.” Journal of Labor Economics 3(1): 11-37.

Paxson, Christina H., and Nachum Sicherman. 1996. "The dynamics of dual job holding and job mobility.” Journal of Labor Economics 14(3): 357-393.

Pistaferri, Luigi. 2003. “Anticipated and Unanticipated Wage Changes, Wage Risk, and Intertemporal Labor Supply.” Journal of Labor Economics 21(3): 729-754.

Shishko, Robert, and Bernard Rostker. 1976. “The Economics of Multiple Job Holdings.” American Economic Review 66(3): 298-308.

Smith Conway, Karen, and Jean Kimmel. 1998. "Male labor supply estimates and the decision to moonlight.” Labor Economics 5: 135-166.

Storesletten, Kjetil, Chris I. Telmer, and Amir Yaron. 2001. "How important are idiosyncratic shocks? Evidence from labor supply.” American Economic Review 91(2): 413417.

Townsend, Robert M. 1994. "Risk and Insurance in Village India.” Econometrica 62(3): 539-591.

UN CESCR. 2007. "Parallel Report to the UN Committee on Economic, Social, and Cultural Rights by the Ukrainian Helsinki Human Rights Union and the International Renaissance Foundation regarding Ukraine's implementation of the International Covenant on Economic, Social and Cultural Rights.” Helsinki.

UNDP. 2005. China Human Development Report 2005-Human Development with Equity. Beijing.

Wooldridge, Jeffrey M. 2002. Econometric Analysis of Cross Section and Panel Data. Cambridge, MA: The MIT Press.

World Bank. 2008. Finance for All. Washington D.C. 
Online Appendix - Not intended for publication 
Table A1: Overview of variables

\begin{tabular}{|c|c|c|c|}
\hline Variable & Mean & Min & Max \\
\hline \multicolumn{4}{|l|}{ Labor market information } \\
\hline Second job & $2.3 \%$ & 0 & 1 \\
\hline Hours second job $h_{2}$ & 0.12 & 0 & 24 \\
\hline Conditional hours in second job, $\left(h_{2} \mid h_{2}>0\right)$ & 5.1 & 0.5 & 24 \\
\hline Subsidiary farming & $61.5 \%$ & 0 & 1 \\
\hline Hours subsidiary farming $h_{2}$ & 9.5 & 0 & 98 \\
\hline Conditional hours in subsidiary farming, $\left(h_{2} \mid h_{2}>0\right)$ & 14.6 & 0 & 98 \\
\hline Hours in main job (reference week) & 40.9 & 1 & 100 \\
\hline Leisure time (hours per week) & 62.3 & 12 & 109 \\
\hline Wage shock $\operatorname{Prob}(\gamma>0)$ (arrear) & $10.6 \%$ & 0 & 1 \\
\hline Intensity of shock $\gamma$ (number of arrear months) & 0.30 & 0 & 69 \\
\hline Conditional intensity of shock $\gamma,(\gamma \mid \gamma>0)$ & 5.2 & 0.1 & 69 \\
\hline Repayment & 0.14 & 0 & 1 \\
\hline Effort related positive shock & $1.2 \%$ & 0 & 1 \\
\hline \multicolumn{4}{|l|}{ Demographic characteristics } \\
\hline Female & $54.9 \%$ & 0 & 1 \\
\hline Married & $71.9 \%$ & 0 & 1 \\
\hline Age & 40.6 & 17 & 60 \\
\hline Adjusted years of schooling & 12.0 & 4 & 15 \\
\hline \multicolumn{4}{|l|}{ Regional characteristics } \\
\hline Village & $27.4 \%$ & 0 & 1 \\
\hline Town & $27.4 \%$ & 0 & 1 \\
\hline City & $45.2 \%$ & 0 & 1 \\
\hline Kiev (region) & $5.5 \%$ & 0 & 1 \\
\hline West (region) & $18.7 \%$ & 0 & 1 \\
\hline East (region) & $27.2 \%$ & 0 & 1 \\
\hline South (region) & $24.9 \%$ & 0 & 1 \\
\hline Centre (region) & $23.7 \%$ & 0 & 1 \\
\hline \multicolumn{4}{|l|}{ Welfare indicators } \\
\hline Asset indicator & 0.3 & -3.398 & 4.346 \\
\hline Log of non-labor income & 5.5 & 0 & 9.1 \\
\hline \multicolumn{4}{|l|}{ Job characteristics } \\
\hline Contractual hourly wage in main job & 2.2 & 0.1 & 45 \\
\hline Economic sector & & 1 & 12 \\
\hline Business ownership category & & 1 & 4 \\
\hline
\end{tabular}

Note: Sample size: 3,472 (balanced sample). Source: ULMS, own calculations. 
Table A2: Correlation matrix for asset items and asset indicator

\begin{tabular}{|c|c|c|c|c|c|c|c|c|c|c|}
\hline & Color TV & $\mathrm{PC}$ & Phone & $\begin{array}{l}\text { Mobile } \\
\text { phone }\end{array}$ & $\begin{array}{l}\text { Refriger- } \\
\text { ator }\end{array}$ & $\begin{array}{l}\text { Washing } \\
\text { machine }\end{array}$ & Car & Motorcycle & Dacha & $\begin{array}{l}\text { Other } \\
\text { apartment, } \\
\text { house }\end{array}$ \\
\hline Color TV & 1 & & & & & & & & & \\
\hline PC & $\begin{array}{l}0.1338 \\
0.000\end{array}$ & 1 & & & & & & & & \\
\hline Phone & $\begin{array}{l}0.2362 \\
0.000\end{array}$ & $\begin{array}{l}0.1877 \\
0.000\end{array}$ & 1 & & & & & & & \\
\hline Mobile phone & $\begin{array}{l}0.1636 \\
0.000\end{array}$ & $\begin{array}{l}0.2821 \\
0.000\end{array}$ & $\begin{array}{l}0.1462 \\
0.000\end{array}$ & 1 & & & & & & \\
\hline Refrigerator & $\begin{array}{l}0.3892 \\
0.000\end{array}$ & $\begin{array}{l}0.1004 \\
0.000\end{array}$ & $\begin{array}{l}0.2316 \\
0.000\end{array}$ & $\begin{array}{l}0.1287 \\
0.000\end{array}$ & 1 & & & & & \\
\hline Washing machine & $\begin{array}{l}0.3108 \\
0.000\end{array}$ & $\begin{array}{l}0.1237 \\
0.000\end{array}$ & $\begin{array}{l}0.2022 \\
0.000\end{array}$ & $\begin{array}{l}0.1389 \\
0.000\end{array}$ & $\begin{array}{l}0.3281 \\
0.000\end{array}$ & 1 & & & & \\
\hline Car & $\begin{array}{l}0.1828 \\
0.000\end{array}$ & $\begin{array}{l}0.1398 \\
0.000\end{array}$ & $\begin{array}{l}0.191 \\
0.000\end{array}$ & $\begin{array}{l}0.2116 \\
0.000\end{array}$ & $\begin{array}{l}0.1596 \\
0.000\end{array}$ & $\begin{array}{l}0.1949 \\
0.000\end{array}$ & 1 & & & \\
\hline Motorcycle & $\begin{array}{l}0.0625 \\
0.000\end{array}$ & $\begin{array}{l}-0.0387 \\
0.000\end{array}$ & $\begin{array}{l}-0.0298 \\
0.000\end{array}$ & $\begin{array}{l}-0.0139 \\
0.082\end{array}$ & $\begin{array}{l}0.0344 \\
0.000\end{array}$ & $\begin{array}{l}0.0573 \\
0.000\end{array}$ & $\begin{array}{l}0.0248 \\
0.002\end{array}$ & 1 & & \\
\hline Dacha & $\begin{array}{l}0.0907 \\
0.000\end{array}$ & $\begin{array}{l}0.0755 \\
0.000\end{array}$ & $\begin{array}{l}0.1399 \\
0.000\end{array}$ & $\begin{array}{l}0.0639 \\
0.000\end{array}$ & $\begin{array}{l}0.0891 \\
0.000\end{array}$ & $\begin{array}{l}0.0881 \\
0.000\end{array}$ & $\begin{array}{l}0.1111 \\
0.000\end{array}$ & $\begin{array}{l}0.0114 \\
0.154\end{array}$ & 1 & \\
\hline Other apartment, house & $\begin{array}{l}0.0177 \\
0.027\end{array}$ & $\begin{array}{l}0.0273 \\
0.001\end{array}$ & $\begin{array}{l}0.0132 \\
0.097\end{array}$ & $\begin{array}{l}0.0608 \\
0.000\end{array}$ & $\begin{array}{l}0.0084 \\
0.290\end{array}$ & $\begin{array}{l}0.0282 \\
0.000\end{array}$ & $\begin{array}{l}0.0291 \\
0.000\end{array}$ & $\begin{array}{l}0.0349 \\
0.000\end{array}$ & $\begin{array}{l}0.0769 \\
0.000\end{array}$ & 1 \\
\hline Score for component 1 & $\begin{array}{l}0.6491 \\
0.000\end{array}$ & $\begin{array}{l}0.4401 \\
0.000\end{array}$ & $\begin{array}{l}0.5609 \\
0.000\end{array}$ & $\begin{array}{l}0.4777 \\
0.000\end{array}$ & $\begin{array}{l}0.6254 \\
0.000\end{array}$ & $\begin{array}{l}0.6078 \\
0.000\end{array}$ & $\begin{array}{l}0.5038 \\
0.000\end{array}$ & $\begin{array}{l}0.0592 \\
0.000\end{array}$ & $\begin{array}{l}0.2966 \\
0.000\end{array}$ & $\begin{array}{l}0.0996 \\
0.000\end{array}$ \\
\hline
\end{tabular}

Note: Reported values are factor predictions from Principal Component analysis. Sample size: 3,472 (balanced sample). The table displays pair wise correlation coefficients; p-values of significance levels in italics. Source: ULMS, own calculations. 
Table A3: Hours responses to wage shocks, intensive margin

$\begin{array}{llllll}(1) & (2) & (3) & \text { (4) } & \text { (5) }\end{array}$

\begin{tabular}{|c|c|c|c|c|c|c|}
\hline \multirow[t]{2}{*}{ Dependent variable } & \multicolumn{6}{|c|}{ Hours in second job } \\
\hline & FE & $\mathrm{FE}$ & FE & FE & FE & FE \\
\hline Wage shock & $\begin{array}{c}0.206^{* *} \\
(0.093)\end{array}$ & & & $\begin{array}{c}0.182 * \\
(0.094)\end{array}$ & & \\
\hline Intensity of wage shock & & $\begin{array}{c}0.082 * * * \\
(0.011)\end{array}$ & & & $\begin{array}{c}0.080 * * * \\
(0.011)\end{array}$ & \\
\hline Repayment & & & $\begin{array}{c}-1.505 * * * \\
(0.553)\end{array}$ & & & $\begin{array}{c}-1.474 * * * \\
(0.557)\end{array}$ \\
\hline Log hours main job & $\begin{array}{c}-0.169 * * \\
(0.085)\end{array}$ & $\begin{array}{c}-0.170 * * \\
(0.084)\end{array}$ & $\begin{array}{c}-0.182^{* *} \\
(0.085)\end{array}$ & $\begin{array}{c}-0.222 * * \\
(0.100)\end{array}$ & $\begin{array}{c}-0.231 * * \\
(0.098)\end{array}$ & $\begin{array}{c}-0.245^{* *} \\
(0.100)\end{array}$ \\
\hline Demographic controls & $\mathrm{X}$ & $\mathrm{X}$ & $\mathrm{X}$ & $\mathrm{X}$ & $\mathrm{X}$ & $\mathrm{X}$ \\
\hline Job \& wealth controls & - & - & - & $\mathrm{X}$ & $\mathrm{X}$ & $\mathrm{X}$ \\
\hline R-squared & 0.007 & 0.034 & 0.008 & 0.017 & 0.043 & 0.019 \\
\hline Observations & 3472 & 3472 & 3472 & 3472 & 3472 & 3472 \\
\hline
\end{tabular}


Table A4: Full list of main regressors, extensive margin, OLS model

Comparison of maximal sample (col. 1 to 8) with constant sample size (col. 9 and 10)

(1)

(2)

(3)

(4)

(5)

(6)

(7)

(8)

(9)

(10)

Dependent variable

Second job holding indicator (0/1)

\begin{tabular}{|c|c|c|c|c|c|c|c|c|c|c|}
\hline & \multicolumn{4}{|c|}{ Maximal sample } & \multicolumn{4}{|c|}{ Maximal sample } & \multicolumn{2}{|c|}{ Constant sample } \\
\hline & OLS & OLS & OLS & OLS & OLS & OLS & OLS & OLS & OLS & OLS \\
\hline Wage arrear & $\begin{array}{l}0.021 * * \\
(0.010)\end{array}$ & & & & $\begin{array}{c}0.023 * * \\
(0.010)\end{array}$ & & & & $\begin{array}{l}0.023 * * \\
(0.011)\end{array}$ & $\begin{array}{c}0.024 * * \\
(0.011)\end{array}$ \\
\hline Number of arrears & & $\begin{array}{c}0.004 \\
(0.003)\end{array}$ & & & & $\begin{array}{c}0.004 \\
(0.003)\end{array}$ & & & & \\
\hline Repayment & & & $\begin{array}{c}-0.026 * * * \\
(0.008)\end{array}$ & & & & $\begin{array}{c}-0.028 * * * \\
(0.009)\end{array}$ & & & \\
\hline Positive shock & & & & $\begin{array}{c}0.032 \\
(0.033)\end{array}$ & & & & $\begin{array}{c}0.031 \\
(0.035)\end{array}$ & & \\
\hline Female & $\begin{array}{c}0.001 \\
(0.005)\end{array}$ & $\begin{array}{c}0.001 \\
(0.005)\end{array}$ & $\begin{array}{c}0.000 \\
(0.005)\end{array}$ & $\begin{array}{c}0.000 \\
(0.005)\end{array}$ & $\begin{array}{c}0.002 \\
(0.006)\end{array}$ & $\begin{array}{c}0.002 \\
(0.006)\end{array}$ & $\begin{array}{c}0.001 \\
(0.006)\end{array}$ & $\begin{array}{c}0.000 \\
(0.006)\end{array}$ & $\begin{array}{c}0.003 \\
(0.006)\end{array}$ & $\begin{array}{c}0.002 \\
(0.006)\end{array}$ \\
\hline Age & $\begin{array}{c}0.002 \\
(0.002)\end{array}$ & $\begin{array}{c}0.002 \\
(0.002)\end{array}$ & $\begin{array}{c}0.002 \\
(0.002)\end{array}$ & $\begin{array}{c}0.002 \\
(0.002)\end{array}$ & $\begin{array}{c}0.003 \\
(0.002)\end{array}$ & $\begin{array}{c}0.003 \\
(0.002)\end{array}$ & $\begin{array}{c}0.003 \\
(0.002)\end{array}$ & $\begin{array}{c}0.003 \\
(0.002)\end{array}$ & $\begin{array}{c}0.001 \\
(0.002)\end{array}$ & $\begin{array}{c}0.003 \\
(0.002)\end{array}$ \\
\hline Age squared/100 & $\begin{array}{l}-0.003 \\
(0.002)\end{array}$ & $\begin{array}{c}-0.003 \\
(0.002)\end{array}$ & $\begin{array}{c}-0.003 \\
(0.002)\end{array}$ & $\begin{array}{c}-0.003 \\
(0.002)\end{array}$ & $\begin{array}{c}-0.004 \\
(0.003)\end{array}$ & $\begin{array}{c}-0.004 \\
(0.003)\end{array}$ & $\begin{array}{c}-0.004 \\
(0.003)\end{array}$ & $\begin{array}{c}-0.004 \\
(0.003)\end{array}$ & $\begin{array}{l}-0.002 \\
(0.003)\end{array}$ & $\begin{array}{c}-0.004 \\
(0.003)\end{array}$ \\
\hline Years of education & $\begin{array}{c}0.004^{* * *} \\
(0.001)\end{array}$ & $\begin{array}{c}0.004^{* * *} \\
(0.001)\end{array}$ & $\begin{array}{c}0.004^{* * *} \\
(0.001)\end{array}$ & $\begin{array}{c}0.004^{* * *} \\
(0.001)\end{array}$ & $\begin{array}{c}0.004^{* * *} \\
(0.001)\end{array}$ & $\begin{array}{c}0.004^{* * *} \\
(0.001)\end{array}$ & $\begin{array}{c}0.004^{* * *} \\
(0.001)\end{array}$ & $\begin{array}{c}0.004^{* * *} \\
(0.001)\end{array}$ & $\begin{array}{c}0.004^{* * *} \\
(0.001)\end{array}$ & $\begin{array}{c}0.003 * * \\
(0.001)\end{array}$ \\
\hline $\begin{array}{l}\text { Second job hourly shadow } \\
\text { wage }\end{array}$ & $\begin{array}{l}0.001^{*} \\
(0.000)\end{array}$ & $\begin{array}{l}0.001^{*} \\
(0.000)\end{array}$ & $\begin{array}{c}0.001 \\
(0.000)\end{array}$ & $\begin{array}{c}0.001 \\
(0.000)\end{array}$ & $\begin{array}{c}0.001 \\
(0.000)\end{array}$ & $\begin{array}{c}0.001 \\
(0.000)\end{array}$ & $\begin{array}{c}0.001 \\
(0.000)\end{array}$ & $\begin{array}{c}0.001 \\
(0.000)\end{array}$ & $\begin{array}{l}0.001^{*} \\
(0.000)\end{array}$ & $\begin{array}{c}0.001 \\
(0.000)\end{array}$ \\
\hline Log hours main job & $\begin{array}{c}-0.027 * * * \\
(0.010)\end{array}$ & $\begin{array}{c}-0.026^{* *} \\
(0.010)\end{array}$ & $\begin{array}{c}-0.027 * * * \\
(0.010)\end{array}$ & $\begin{array}{c}-0.027 * * * \\
(0.010)\end{array}$ & $\begin{array}{l}-0.021^{*} \\
(0.012)\end{array}$ & $\begin{array}{l}-0.021 * \\
(0.012)\end{array}$ & $\begin{array}{l}-0.023^{*} \\
(0.012)\end{array}$ & $\begin{array}{c}-0.024 * * \\
(0.012)\end{array}$ & $\begin{array}{l}-0.021 * \\
(0.011)\end{array}$ & $\begin{array}{l}-0.020 \\
(0.013)\end{array}$ \\
\hline Village & $\begin{array}{l}-0.001 \\
(0.007)\end{array}$ & $\begin{array}{l}-0.001 \\
(0.007)\end{array}$ & $\begin{array}{l}-0.000 \\
(0.007)\end{array}$ & $\begin{array}{c}0.000 \\
(0.007)\end{array}$ & $\begin{array}{l}-0.001 \\
(0.007)\end{array}$ & $\begin{array}{l}-0.001 \\
(0.007)\end{array}$ & $\begin{array}{l}-0.000 \\
(0.007)\end{array}$ & $\begin{array}{l}-0.000 \\
(0.007)\end{array}$ & $\begin{array}{l}-0.008 \\
(0.008)\end{array}$ & $\begin{array}{c}-0.005 \\
(0.008)\end{array}$ \\
\hline Town & -0.004 & -0.004 & -0.004 & -0.004 & 0.000 & -0.000 & -0.000 & -0.000 & -0.002 & -0.000 \\
\hline
\end{tabular}




\begin{tabular}{|c|c|c|c|c|c|c|c|c|c|c|}
\hline Married & $(0.007)$ & $(0.007)$ & $(0.007)$ & $(0.007)$ & $(0.007)$ & $(0.007)$ & $(0.007)$ & $(0.007)$ & $(0.008)$ & $(0.007)$ \\
\hline \multirow[t]{2}{*}{ Asset indicator } & & & & & 0.002 & 0.002 & 0.001 & 0.002 & & 0.001 \\
\hline & & & & & $(0.002)$ & $(0.002)$ & $(0.002)$ & $(0.002)$ & & $(0.002)$ \\
\hline Hourly wage main job & & & & & $\begin{array}{c}0.003 \\
(0.002)\end{array}$ & $\begin{array}{c}0.003 \\
(0.002)\end{array}$ & $\begin{array}{c}0.002 \\
(0.002)\end{array}$ & $\begin{array}{c}0.002 \\
(0.002)\end{array}$ & & $\begin{array}{c}0.001 \\
(0.002)\end{array}$ \\
\hline East & $\begin{array}{c}0.003 \\
(0.006)\end{array}$ & $\begin{array}{c}0.004 \\
(0.006)\end{array}$ & $\begin{array}{c}0.003 \\
(0.006)\end{array}$ & $\begin{array}{c}0.003 \\
(0.006)\end{array}$ & $\begin{array}{c}0.002 \\
(0.006)\end{array}$ & $\begin{array}{c}0.003 \\
(0.006)\end{array}$ & $\begin{array}{c}0.003 \\
(0.006)\end{array}$ & $\begin{array}{c}0.003 \\
(0.006)\end{array}$ & $\begin{array}{c}0.010 \\
(0.007)\end{array}$ & $\begin{array}{c}0.007 \\
(0.006)\end{array}$ \\
\hline South & $\begin{array}{c}0.019 * * \\
(0.009)\end{array}$ & $\begin{array}{c}0.019^{* *} \\
(0.009)\end{array}$ & $\begin{array}{c}0.018^{* *} \\
(0.008)\end{array}$ & $\begin{array}{c}0.018^{* *} \\
(0.009)\end{array}$ & $\begin{array}{c}0.020^{* *} \\
(0.008)\end{array}$ & $\begin{array}{c}0.020 * * \\
(0.008)\end{array}$ & $\begin{array}{c}0.019 * * \\
(0.008)\end{array}$ & $\begin{array}{c}0.019 * * \\
(0.008)\end{array}$ & $\begin{array}{c}0.025^{* * * *} \\
(0.009)\end{array}$ & $\begin{array}{c}0.023 * * \\
(0.009)\end{array}$ \\
\hline Time & $\begin{array}{c}0.002 \\
(0.004)\end{array}$ & $\begin{array}{c}0.002 \\
(0.004)\end{array}$ & $\begin{array}{c}0.001 \\
(0.004)\end{array}$ & $\begin{array}{c}0.001 \\
(0.004)\end{array}$ & $\begin{array}{l}-0.001 \\
(0.004)\end{array}$ & $\begin{array}{l}-0.001 \\
(0.004)\end{array}$ & $\begin{array}{l}-0.002 \\
(0.004)\end{array}$ & $\begin{array}{l}-0.001 \\
(0.004)\end{array}$ & $\begin{array}{c}0.005 \\
(0.004)\end{array}$ & $\begin{array}{c}0.005 \\
(0.005)\end{array}$ \\
\hline Observations & 4282 & 4282 & 4282 & 4282 & 4022 & 4022 & 4022 & 4022 & 3472 & 3472 \\
\hline
\end{tabular}


Table A5a: Full list of main regressors, extensive margin second job holdings, FE model Comparison of maximal sample (col. 1 to 8) with constant sample size (col. 9 and 10)

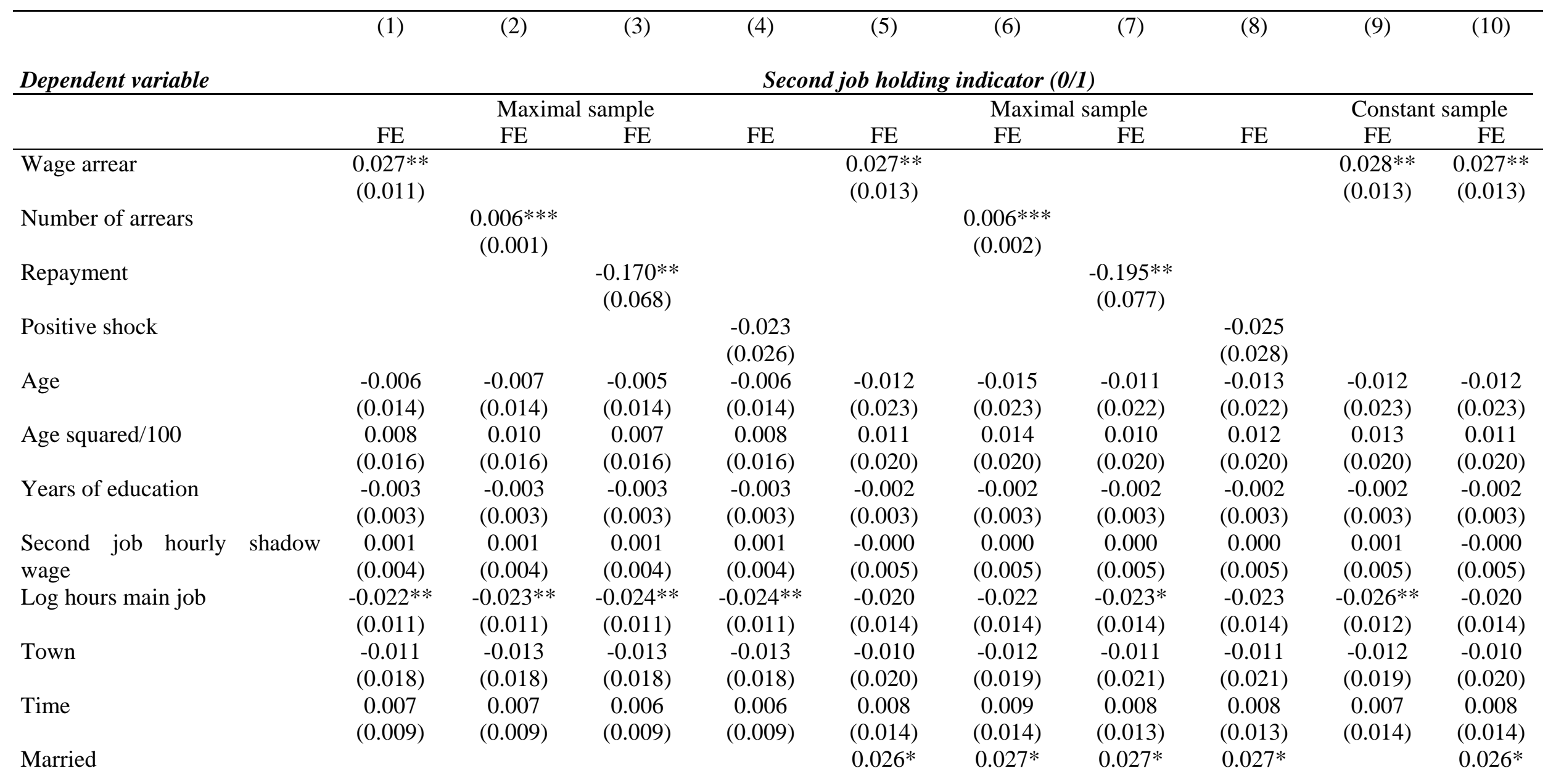




\begin{tabular}{|c|c|c|c|c|c|c|c|c|c|c|}
\hline & & & & & $(0.015)$ & $(0.015)$ & $(0.015)$ & $(0.015)$ & & $(0.015)$ \\
\hline \multirow[t]{2}{*}{ Asset indicator } & & & & & -0.003 & -0.003 & -0.003 & -0.003 & & -0.003 \\
\hline & & & & & $(0.004)$ & $(0.004)$ & $(0.004)$ & $(0.004)$ & & $(0.004)$ \\
\hline \multirow[t]{2}{*}{ Log of non labor income } & & & & & $0.005^{* *}$ & $0.005^{* *}$ & $0.005^{* *}$ & $0.005^{* *}$ & & $0.005 * *$ \\
\hline & & & & & $(0.002)$ & $(0.002)$ & $(0.002)$ & $(0.002)$ & & $(0.002)$ \\
\hline \multirow[t]{2}{*}{ Hourly wage rate main job } & & & & & 0.002 & 0.001 & 0.001 & 0.001 & & 0.002 \\
\hline & & & & & $(0.003)$ & $(0.002)$ & $(0.002)$ & $(0.003)$ & & $(0.003)$ \\
\hline \multirow[t]{2}{*}{ Constant } & 0.228 & 0.260 & 0.237 & 0.246 & 0.295 & 0.385 & 0.334 & 0.335 & 0.390 & 0.332 \\
\hline & $(0.329)$ & $(0.328)$ & $(0.329)$ & $(0.330)$ & $(0.641)$ & $(0.640)$ & $(0.639)$ & $(0.640)$ & $(0.639)$ & $(0.665)$ \\
\hline Sector and job characteristics & - & - & - & - & $\mathrm{X}$ & $X$ & $X$ & $X$ & - & $X$ \\
\hline R-squared & 0.007 & 0.012 & 0.007 & 0.005 & 0.022 & 0.028 & 0.024 & 0.020 & 0.007 & 0.023 \\
\hline Observations & 4282 & 4282 & 4282 & 4282 & 4022 & 4022 & 4022 & 4022 & 3472 & 3472 \\
\hline
\end{tabular}

Note: Robust standard errors in parentheses are clustered by id; *** $\mathrm{p}<0.01,{ }^{* *} \mathrm{p}<0.05,{ }^{*} \mathrm{p}<0.1$. Source: ULMS, own calculations.

Table A5b: Full list of main regressors, extensive margin, subsidiary farming, FE model Comparison of maximal sample (col. 1 to 8) with constant sample size (col. 9 and 10)
(1)
(2)
(3)
(4)
(5)
(6)
(7)
(8)
(9)
(10)

Dependent variable

Subsidiary farming indicator (0/1)






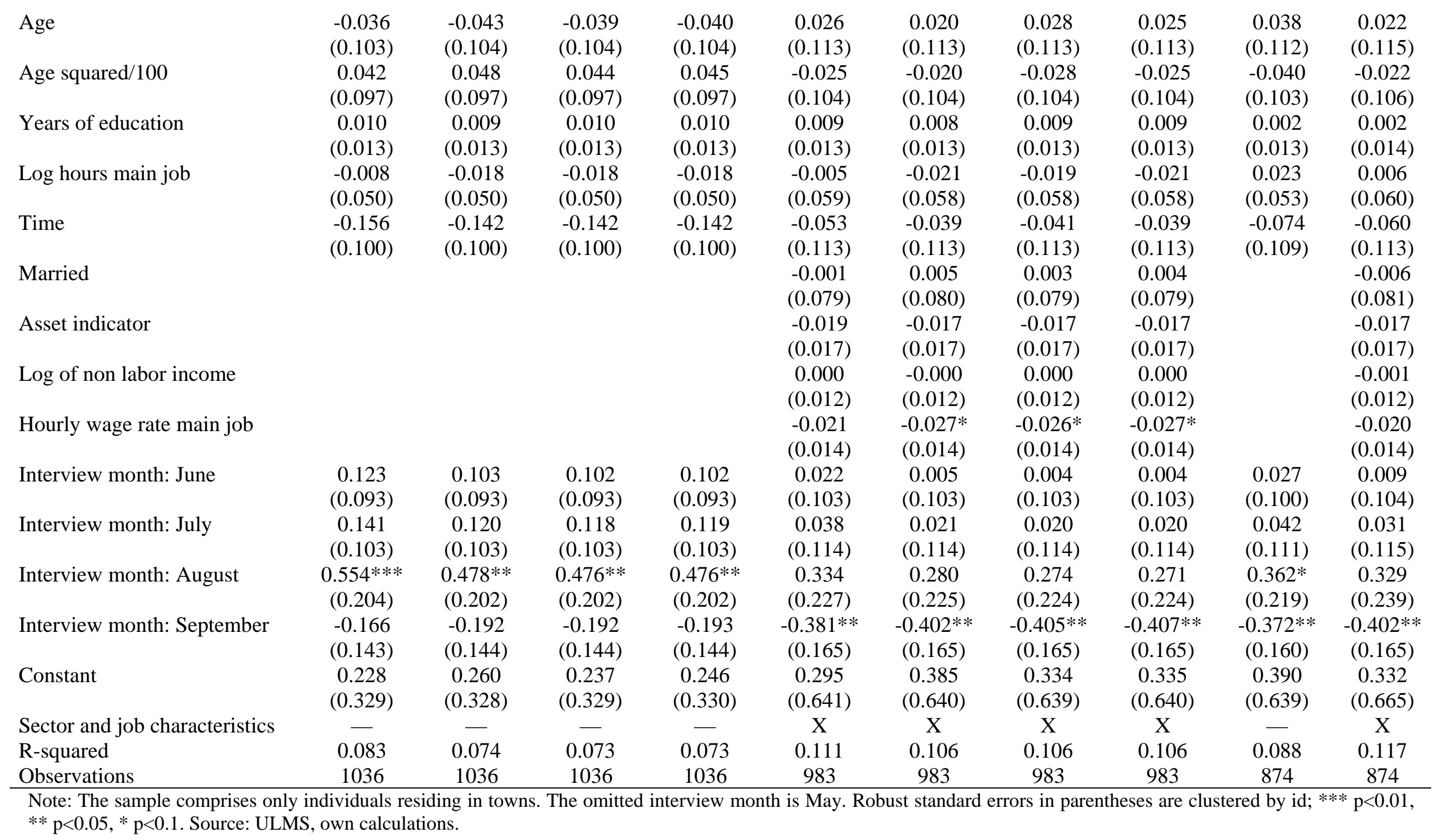


Table A6: Full list of main regressors, intensive margin

(1)
(3)

(4)
(5)
(6)

\begin{tabular}{|c|c|c|c|c|c|c|c|c|}
\hline \multirow[t]{2}{*}{ Dependent variable } & \multicolumn{4}{|c|}{ Hours in second job } & \multicolumn{4}{|c|}{ Hours in subsidiary farming } \\
\hline & Tobit & Tobit & RE Tobit & RE Tobit & Tobit & Tobit & RE Tobit & RE Tobit \\
\hline \multirow[t]{2}{*}{ Wage shock } & $4.924 * * *$ & $4.758 * * *$ & $4.870 * * *$ & $5.094 * * *$ & $4.661 * * *$ & $2.878 * *$ & $3.932 * * *$ & $2.293 * *$ \\
\hline & $(1.779)$ & $(1.788)$ & $(1.862)$ & $(1.909)$ & $(1.161)$ & $(1.215)$ & (1.183) & $(1.112)$ \\
\hline \multirow[t]{2}{*}{ Hours main job } & $-0.098 *$ & $-0.104^{*}$ & $-0.128 * *$ & $-0.124^{*}$ & $-0.200 * * *$ & $-0.231 * * *$ & $-0.212 * * *$ & $-0.240 * * *$ \\
\hline & $(0.057)$ & $(0.060)$ & $(0.061)$ & $(0.064)$ & $(0.035)$ & $(0.037)$ & $(0.042)$ & $(0.047)$ \\
\hline \multirow{2}{*}{ Second job shadow hr. wage } & $0.166 * *$ & $0.159 * *$ & $0.183 * *$ & $0.170 *$ & & & & \\
\hline & $(0.074)$ & $(0.074)$ & $(0.087)$ & $(0.087)$ & & & & \\
\hline \multirow[t]{2}{*}{ Female } & 0.800 & 0.308 & 0.422 & 0.086 & $2.525 * * *$ & $3.038 * * *$ & $2.424 * * *$ & $3.035 * *$ \\
\hline & (1.288) & (1.338) & (1.512) & $(1.636)$ & $(0.803)$ & $(0.888)$ & $(0.894)$ & $(1.206)$ \\
\hline \multirow[t]{2}{*}{ Age } & 0.168 & 0.518 & 0.068 & 0.364 & $1.667 * * *$ & $1.246 * * *$ & $1.639 * * *$ & $1.225 * * *$ \\
\hline & $(0.455)$ & (0.469) & $(0.531)$ & (0.549) & $(0.301)$ & $(0.309)$ & $(0.360)$ & $(0.395)$ \\
\hline \multirow[t]{2}{*}{ Age squared/100 } & -0.315 & -0.714 & -0.192 & -0.551 & $-1.719 * * *$ & $-1.283 * * *$ & $-1.676 * * *$ & $-1.250 * *$ \\
\hline & $(0.572)$ & $(0.585)$ & $(0.667)$ & $(0.685)$ & $(0.376)$ & $(0.384)$ & $(0.452)$ & $(0.495)$ \\
\hline \multirow[t]{2}{*}{ Years of education } & $0.873 * * *$ & $0.789 * *$ & $0.682 *$ & $0.628 *$ & -0.173 & -0.019 & -0.186 & -0.050 \\
\hline & $(0.323)$ & $(0.331)$ & $(0.356)$ & $(0.370)$ & (0.193) & $(0.202)$ & (0.169) & $(0.174)$ \\
\hline \multirow[t]{2}{*}{ Village } & -0.729 & 0.038 & -1.132 & -1.650 & $10.166^{* * *}$ & $8.737 * * *$ & $10.258 * * *$ & $8.873 * * *$ \\
\hline & (1.792) & (1.826) & (2.121) & (2.311) & $(0.816)$ & $(0.835)$ & (0.868) & $(1.161)$ \\
\hline \multirow[t]{2}{*}{ Town } & 0.722 & 1.112 & 0.543 & 0.453 & & & & \\
\hline & (1.507) & (1.528) & $(1.750)$ & (1.796) & & & & \\
\hline \multirow[t]{2}{*}{ Kiev } & 4.813 & 3.386 & 4.619 & 2.555 & & & & \\
\hline & (3.221) & (3.164) & $(3.765)$ & (3.779) & & & & \\
\hline \multirow[t]{2}{*}{ West } & $7.488 * * *$ & $6.720 * * *$ & $7.454 * * *$ & $7.154 * * *$ & $-1.995^{*}$ & -1.351 & -2.019 & -1.347 \\
\hline & (2.237) & (2.208) & $(2.584)$ & (2.592) & (1.067) & (1.065) & (1.234) & $(1.262)$ \\
\hline \multirow[t]{2}{*}{ East } & $4.023^{*}$ & 3.164 & 4.063 & 3.398 & $-5.651 * * *$ & $-4.745 * * *$ & $-5.605 * * *$ & $-4.795 * * *$ \\
\hline & (2.308) & (2.288) & (2.645) & (2.655) & (1.078) & (1.107) & (1.226) & $(0.904)$ \\
\hline \multirow[t]{2}{*}{ South } & $7.351 * * *$ & $6.407 * * *$ & $7.055 * *$ & $6.253^{* *}$ & $-4.132 * * *$ & $-3.989 * * *$ & $-4.404 * * *$ & $-4.245 * * *$ \\
\hline & $(2.470)$ & $(2.442)$ & $(2.835)$ & $(2.824)$ & (1.115) & (1.112) & (1.305) & (1.273) \\
\hline
\end{tabular}


Time

Married

Asset indicator

Log non-labor income

Hourly wage main job

Job controls

Interview month controls

Rho

LI

Pseudo R-squared / Chi2

Observations

$$
0.897
$$

$$
\text { (1.219) }
$$

0.837
$(1.247)$

$-2.198$

(1.452)

$-0.060$

(0.511)

$2.404^{* * *}$

(0.679)

0.010

(0.385)

$\underline{\mathrm{X}}$

$\begin{array}{ll}\mathrm{X} & \mathrm{X} \\ - & -\end{array}$

X

$-572.3$

0.039

3472

$-559.5$

0.060

3472

$\begin{array}{cc}1.138 & 0.861 \\ (1.045) & (1.062) \\ & -1.741 \\ & (1.617) \\ & -0.256 \\ & (0.551) \\ & 2.505^{* * *} \\ & (0.688) \\ & -0.018 \\ & (0.400)\end{array}$

X

0.683

$-547.9$

24.33

3472

$\mathrm{X}$
0.719
-532.3
34.09
3472

1.319

(1.953)

1.589

(1.947)

$-0.085$

0.316

(2.091)

$5.151 * * *$

(1.124)

(1.005)

$-0.497$

-0.535*

(0.339)

$-0.063$

$-0.043$

(0.238)

(0.246)

$-0.632 * *$

$-0.587$

$(0.299)$

$\begin{array}{cccc}X & X & X & X \\ X & X & X & X \\ & & 0.388 & 0.374 \\ -6287 & -6256 & -6224 & -6198 \\ 0.0319 & 0.0367 & 359.6 & 1161 \\ 1834 & 1834 & 1834 & 1834\end{array}$

$* * \mathrm{p}<0.05,{ }^{*} \mathrm{p}<0.1$. Source: ULMS, own calculations. 
Table A7: Shock response patterns in second jobs by geographic location

\begin{tabular}{|c|c|c|c|c|c|c|}
\hline & (1) & (2) & (3) & (4) & (5) & (6) \\
\hline & $\begin{array}{l}\text { Town \& } \\
\text { Village }\end{array}$ & City & Town \& Village & City & Town \& Village & City \\
\hline \multirow[t]{2}{*}{ Dependent variables } & \multicolumn{2}{|c|}{ Second job } & \multicolumn{2}{|c|}{ Log hours main job } & \multicolumn{2}{|c|}{ Log leisure } \\
\hline & RE & $\mathrm{RE}$ & $\mathrm{FE}$ & FE & $\mathrm{RE}$ & $\mathrm{RE}$ \\
\hline \multirow[t]{2}{*}{ Wage shock } & $0.025 * *$ & $0.034 * *$ & $-0.066 * *$ & -0.038 & $-0.045 *$ & -0.013 \\
\hline & $(0.011)$ & $(0.016)$ & $(0.033)$ & $(0.047)$ & $(0.025)$ & $(0.021)$ \\
\hline \multirow[t]{2}{*}{ Log non-labor income } & $0.005^{* *}$ & $0.009 * * *$ & -0.002 & -0.004 & -0.005 & -0.002 \\
\hline & $(0.002)$ & $(0.003)$ & $(0.006)$ & $(0.007)$ & $(0.005)$ & $(0.003)$ \\
\hline \multirow[t]{2}{*}{ Hourly wage main job } & -0.001 & 0.003 & & & $0.034 * * *$ & $0.021 * * *$ \\
\hline & $(0.002)$ & $(0.002)$ & & & $(0.006)$ & $(0.003)$ \\
\hline Rho & 0.236 & 0.377 & 0.627 & 0.516 & 0.211 & 0.290 \\
\hline (Pseudo) R-squared & 0.034 & 0.048 & 0.026 & 0.033 & 0.189 & 0.108 \\
\hline Observations & 1904 & 1568 & 1904 & 1568 & 1904 & 1568 \\
\hline
\end{tabular}

Note: Standard errors in parentheses; ${ }^{* * *} \mathrm{p}<0.01,{ }^{* *} \mathrm{p}<0.05$, ${ }^{*} \mathrm{p}<0.1$. Source: ULMS, own calculations. 
Table A8: First stage of G2SLS model

(1) (2) (3)

(4)

Dependent variable:

Wage shock instrument (UHBS)

Wage shock indicator (0/1)

\begin{tabular}{|c|c|c|c|c|}
\hline & $(0.077)$ & $(0.076)$ & $(0.134)$ & $(0.133)$ \\
\hline Female & $\begin{array}{l}-0.013 \\
(0.011)\end{array}$ & $\begin{array}{c}-0.042^{* * * *} \\
(0.011)\end{array}$ & $\begin{array}{c}0.007 \\
(0.019)\end{array}$ & $\begin{array}{c}-0.046^{* *} \\
(0.020)\end{array}$ \\
\hline Age & $\begin{array}{c}0.011^{* * *} \\
(0.004)\end{array}$ & $\begin{array}{c}0.014 * * * \\
(0.004)\end{array}$ & $\begin{array}{l}0.012^{*} \\
(0.007)\end{array}$ & $\begin{array}{c}0.016^{* *} \\
(0.007)\end{array}$ \\
\hline Age squared/100 & $\begin{array}{c}-0.018 * * * \\
(0.005)\end{array}$ & $\begin{array}{c}-0.022 * * * \\
(0.005)\end{array}$ & $\begin{array}{c}-0.022^{* *} \\
(0.009)\end{array}$ & $\begin{array}{c}-0.025^{* * *} * \\
(0.009)\end{array}$ \\
\hline Years of education & $\begin{array}{c}0.002 \\
(0.002)\end{array}$ & $\begin{array}{c}0.008 * * * \\
(0.003)\end{array}$ & $\begin{array}{l}-0.002 \\
(0.004)\end{array}$ & $\begin{array}{c}0.005 \\
(0.005)\end{array}$ \\
\hline Kiev & $\begin{array}{l}-0.006 \\
(0.026)\end{array}$ & $\begin{array}{l}-0.003 \\
(0.026)\end{array}$ & NA & NA \\
\hline West & $\begin{array}{l}-0.015 \\
(0.016)\end{array}$ & $\begin{array}{l}-0.019 \\
(0.016)\end{array}$ & NA & NA \\
\hline East & $\begin{array}{c}0.009 \\
(0.015)\end{array}$ & $\begin{array}{c}0.004 \\
(0.016)\end{array}$ & $\begin{array}{c}-0.012 \\
(0.023)\end{array}$ & $\begin{array}{c}0.002 \\
(0.023)\end{array}$ \\
\hline South & $\begin{array}{l}-0.012 \\
(0.017)\end{array}$ & $\begin{array}{l}-0.030^{*} \\
(0.017)\end{array}$ & $\begin{array}{l}-0.020 \\
(0.024)\end{array}$ & $\begin{array}{l}-0.014 \\
(0.024)\end{array}$ \\
\hline Village & $\begin{array}{c}0.079 * * * \\
(0.014)\end{array}$ & $\begin{array}{c}0.037^{* *} \\
(0.014)\end{array}$ & $\begin{array}{c}0.060^{* * *} \\
(0.019)\end{array}$ & $\begin{array}{c}0.038^{* *} \\
(0.019)\end{array}$ \\
\hline Town & $\begin{array}{c}0.036 * * * \\
(0.013)\end{array}$ & $\begin{array}{c}0.018 \\
(0.013)\end{array}$ & NA & NA \\
\hline Time & $\begin{array}{c}-0.038^{* * *} \\
(0.010)\end{array}$ & $\begin{array}{c}-0.021^{* *} \\
(0.010)\end{array}$ & $\begin{array}{c}-0.134 * * * \\
(0.047)\end{array}$ & $\begin{array}{c}-0.101^{* *} \\
(0.047)\end{array}$ \\
\hline Log of working hours main job & & $\begin{array}{c}-0.082 * * * \\
(0.017)\end{array}$ & & $\begin{array}{c}-0.002^{* *} \\
(0.001)\end{array}$ \\
\hline Second job hourly wage & & $\begin{array}{c}-0.002 * * * \\
(0.001)\end{array}$ & & NA \\
\hline Log of non-labor income & & $\begin{array}{l}-0.003 \\
(0.003)\end{array}$ & & $\begin{array}{c}0.003 \\
(0.005)\end{array}$ \\
\hline Hourly wage main job & & $\begin{array}{c}-0.032 * * * \\
(0.003)\end{array}$ & & $\begin{array}{c}-0.049 * * * \\
(0.006)\end{array}$ \\
\hline Asset indicator & & $\begin{array}{l}-0.008^{*} \\
(0.004)\end{array}$ & & $\begin{array}{l}-0.012 * \\
(0.007)\end{array}$ \\
\hline Interview month May & & & $\begin{array}{l}-0.009 \\
(0.027)\end{array}$ & $\begin{array}{l}-0.006 \\
(0.027)\end{array}$ \\
\hline Interview month June & & & $\begin{array}{c}0.044 \\
(0.050)\end{array}$ & $\begin{array}{c}0.034 \\
(0.049)\end{array}$ \\
\hline Interview month July & & & $\begin{array}{c}0.088 \\
(0.053)\end{array}$ & $\begin{array}{l}0.088^{*} \\
(0.052)\end{array}$ \\
\hline Interview month August & & & $\begin{array}{l}-0.031 \\
(0.086)\end{array}$ & $\begin{array}{l}-0.020 \\
(0.084)\end{array}$ \\
\hline Constant & $\begin{array}{l}-0.091 \\
(0.098)\end{array}$ & $\begin{array}{c}0.158 \\
(0.104)\end{array}$ & $\begin{array}{l}-0.099 \\
(0.146)\end{array}$ & $\begin{array}{l}-0.063 \\
(0.152)\end{array}$ \\
\hline $\begin{array}{l}\text { Wald chi }(d f) \\
\text { df }\end{array}$ & $\begin{array}{c}255 \\
13\end{array}$ & $\begin{array}{c}389 \\
17\end{array}$ & $\begin{array}{c}152 \\
14\end{array}$ & $\begin{array}{c}228 \\
17\end{array}$ \\
\hline Prob > chi2 & 0.0000 & 0.0000 & 0.0000 & 0.0000 \\
\hline Observations & 3472 & 3472 & 1352 & 1352 \\
\hline
\end{tabular}

Note: Omitted categories: 'Central region', 'city', 'Interview month September'. Detailed region fixed effects and job characteristics are not controlled for, as they are measurement units for the shock instrument. Standard errors in parentheses; ${ }^{* * *} \mathrm{p}<0.01, * * \mathrm{p}<0.05, * \mathrm{p}<0.1$. Source: ULMS, own calculations. 
Table A9: Consumption smoothing model with adult equivalence scales

(1)

(2)

(3)

(4)

(5)

(6)

(7)

(8)

Full sample Full sample Rural sample Urban sample Full sample Rural sample Urban sample Full sample

Dependent variable Log of household consumption

\begin{tabular}{|c|c|c|c|c|c|c|c|c|}
\hline & FE & $\mathrm{FE}$ & $\mathrm{FE}$ & $\mathrm{FE}$ & $\mathrm{FE}$ & $\mathrm{FE}$ & $\mathrm{FE}$ & $\mathrm{FE}$ \\
\hline Log of income & $\begin{array}{c}0.130 * * * \\
(0.007)\end{array}$ & $\begin{array}{c}0.128 * * * \\
(0.007)\end{array}$ & $\begin{array}{c}0.129 * * * \\
(0.010)\end{array}$ & $\begin{array}{c}0.127 * * * \\
(0.010)\end{array}$ & $\begin{array}{c}0.127 * * * \\
(0.007)\end{array}$ & $\begin{array}{c}0.127 * * * \\
(0.010)\end{array}$ & $\begin{array}{c}0.128 * * * \\
(0.010)\end{array}$ & $\begin{array}{c}0.127 * * * \\
(0.007)\end{array}$ \\
\hline Wage arrear in $\mathrm{HH}\left(\delta_{2}\right)$ & $\begin{array}{l}-0.025 * * \\
(0.012)\end{array}$ & $\begin{array}{l}-0.037^{*} \\
(0.021)\end{array}$ & $\begin{array}{l}-0.030 \\
(0.025)\end{array}$ & $\begin{array}{l}-0.050 \\
(0.041)\end{array}$ & $\begin{array}{c}-0.051 * * \\
(0.023)\end{array}$ & $\begin{array}{l}-0.047^{*} \\
(0.028)\end{array}$ & $\begin{array}{l}-0.047 \\
(0.041)\end{array}$ & $\begin{array}{c}-0.055^{* *} * \\
(0.023)\end{array}$ \\
\hline Second job in $\mathrm{HH}\left(\delta_{3}\right)$ & $\begin{array}{l}-0.011 \\
(0.022)\end{array}$ & $\begin{array}{l}-0.033 \\
(0.024)\end{array}$ & $\begin{array}{l}-0.036 \\
(0.035)\end{array}$ & $\begin{array}{l}-0.023 \\
(0.032)\end{array}$ & & & & $\begin{array}{l}-0.034 \\
(0.024)\end{array}$ \\
\hline Arrear*Second job $\left(\delta_{4}\right)$ & & $\begin{array}{l}0.102 * * \\
(0.044)\end{array}$ & $\begin{array}{c}0.078 \\
(0.058)\end{array}$ & $\begin{array}{l}0.155^{* *} \\
(0.070)\end{array}$ & & & & $\begin{array}{l}0.106^{* * *} \\
(0.044)\end{array}$ \\
\hline $\begin{array}{l}\text { Arrear*Increase in sub- } \\
\text { sidiary farming hours }\left(\delta_{5}\right)\end{array}$ & & & & & $\begin{array}{l}0.050^{*} \\
(0.025)\end{array}$ & $\begin{array}{c}0.050 \\
(0.032)\end{array}$ & $\begin{array}{c}0.051 \\
(0.048)\end{array}$ & $\begin{array}{l}0.052 * * \\
(0.025)\end{array}$ \\
\hline Access to credit & & $\begin{array}{c}0.409 \\
(0.502)\end{array}$ & $\begin{array}{c}1.318 \\
(0.850)\end{array}$ & $\begin{array}{c}-2.226 \\
(2.378)\end{array}$ & $\begin{array}{c}0.425 \\
(0.502)\end{array}$ & $\begin{array}{c}1.320 \\
(0.850)\end{array}$ & $\begin{array}{l}-2.250 \\
(2.381)\end{array}$ & $\begin{array}{c}0.436 \\
(0.502)\end{array}$ \\
\hline Arrear*Access credit & & $\begin{array}{c}0.056 \\
(0.242)\end{array}$ & $\begin{array}{c}-0.071 \\
(0.336)\end{array}$ & $\begin{array}{c}0.124 \\
(0.393)\end{array}$ & $\begin{array}{c}0.094 \\
(0.241)\end{array}$ & $\begin{array}{c}-0.065 \\
(0.331)\end{array}$ & $\begin{array}{c}0.109 \\
(0.394)\end{array}$ & $\begin{array}{c}0.045 \\
(0.242)\end{array}$ \\
\hline Town & & $\begin{array}{c}0.100 * * \\
(0.045)\end{array}$ & $\begin{array}{c}0.148 * * \\
(0.058)\end{array}$ & & $\begin{array}{l}0.104^{* *} \\
(0.045)\end{array}$ & $\begin{array}{c}0.149 * * \\
(0.058)\end{array}$ & & $\begin{array}{c}0.103^{* *} \\
(0.045)\end{array}$ \\
\hline Large city & & $\begin{array}{c}0.131^{* * *} \\
(0.047)\end{array}$ & & & $\begin{array}{c}0.136^{* * *} \\
(0.047)\end{array}$ & & & $\begin{array}{c}0.136 * * * \\
(0.047)\end{array}$ \\
\hline Household size & $\begin{array}{c}0.082 * * * \\
(0.013)\end{array}$ & $\begin{array}{c}0.082 * * * \\
(0.013)\end{array}$ & $\begin{array}{c}0.086^{* * *} \\
(0.019)\end{array}$ & $\begin{array}{c}0.077 * * * \\
(0.018)\end{array}$ & $\begin{array}{c}0.083 * * * \\
(0.013)\end{array}$ & $\begin{array}{c}0.089 * * * \\
(0.019)\end{array}$ & $\begin{array}{c}0.077 * * * \\
(0.018)\end{array}$ & $\begin{array}{c}0.082 * * * \\
(0.013)\end{array}$ \\
\hline Constant & $\begin{array}{c}5.477 * * * \\
(0.052)\end{array}$ & $\begin{array}{c}5.377 * * * \\
(0.068)\end{array}$ & $\begin{array}{c}5.331^{* * *} \\
(0.093)\end{array}$ & $\begin{array}{c}5.698 * * * \\
(0.196)\end{array}$ & $\begin{array}{c}5.374 * * * \\
(0.068)\end{array}$ & $\begin{array}{c}5.330 * * * \\
(0.093)\end{array}$ & $\begin{array}{c}5.693^{* * *} \\
(0.196)\end{array}$ & $\begin{array}{c}5.375^{* * *} \\
(0.068)\end{array}$ \\
\hline $\begin{array}{l}\text { (2)-(4): } \delta_{2}+\delta_{3}+\delta_{4} \\
\text { (5)-(7): } \delta_{2}+\delta_{3}+\delta_{5} \\
\text { (8): } \delta_{2}+\delta_{3}+\delta_{4}+\delta_{5}\end{array}$ & & $\begin{array}{c}0.033 \\
(0.045)\end{array}$ & $\begin{array}{c}0.013 \\
(0.058)\end{array}$ & $\begin{array}{c}0.083 \\
(0.074)\end{array}$ & $\begin{array}{l}-0.001 \\
(0.027)\end{array}$ & $\begin{array}{c}0.003 \\
(0.032)\end{array}$ & $\begin{array}{c}0.004 \\
(0.057)\end{array}$ & $\begin{array}{c}0.068 \\
(0.048)\end{array}$ \\
\hline R-squared & 0.165 & 0.171 & 0.173 & 0.175 & 0.170 & 0.173 & 0.171 & 0.172 \\
\hline Observations & 4270 & 4270 & 2222 & 1886 & 4270 & 2222 & 1886 & 4270 \\
\hline
\end{tabular}

Observations

$4270 \quad 4270$

$2222 \quad 1886$

4270

2222

1886

4270

Note: 'HH' stands for 'Household'. Adult equivalence scales according to the Oxford scale. All Hausman tests rejected at the $1 \%$ level. Omitted category: Settlement village. Standard errors in parentheses; $* * * \mathrm{p}<0.01, * * \mathrm{p}<0.05, * \mathrm{p}<0.1$. Source: ULMS, own calculations. 
Table A10a: Second job holding responses to wage shocks, full-time vs. part-time sample
(1)
(2)
(3)
(4)
(5)
(6)
(7)
(8)

Dependent variable

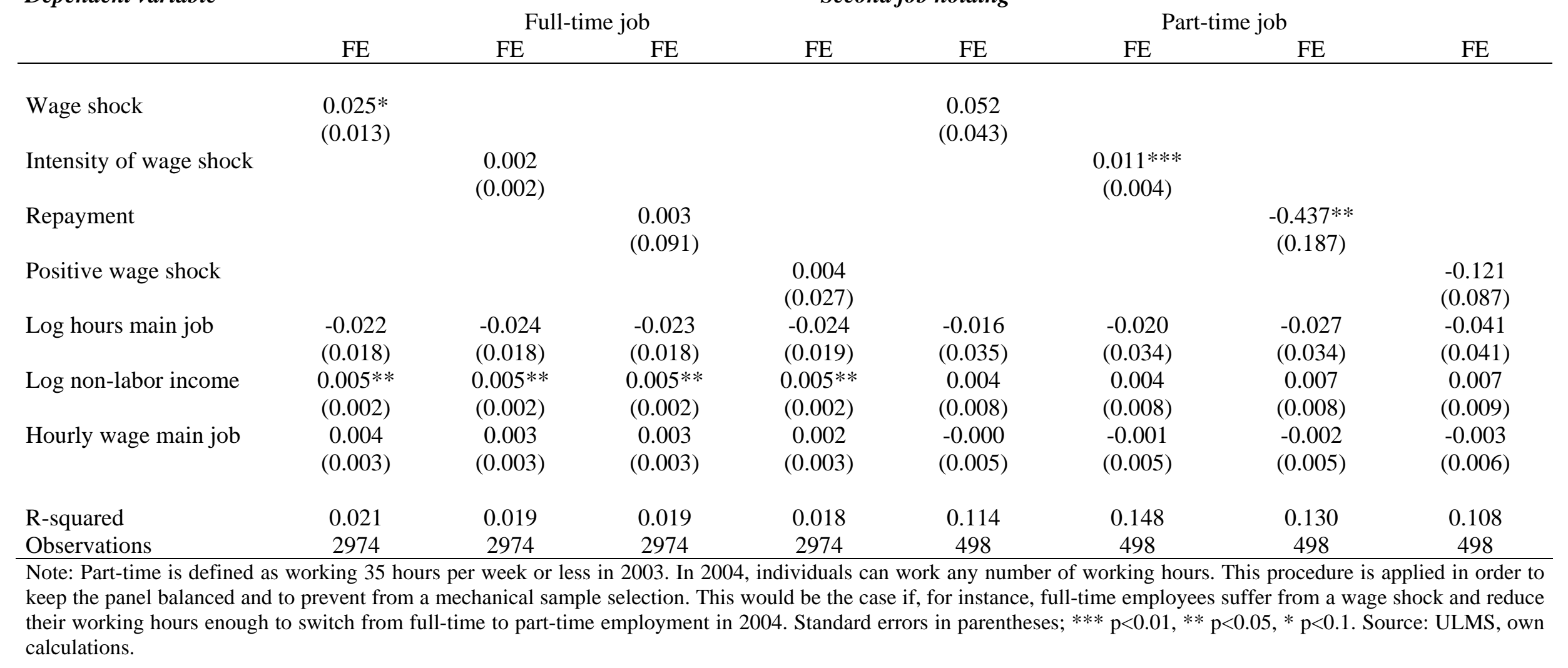

Full-time job

Second job holding 
Table A10b: Subsidiary farming responses to wage shocks, full-time vs. part-time sample
(1)
(2)
(3)
(4)
(5)
(6)
(7)
(8)

Dependent variable

Full-time job

Subsidiary farming

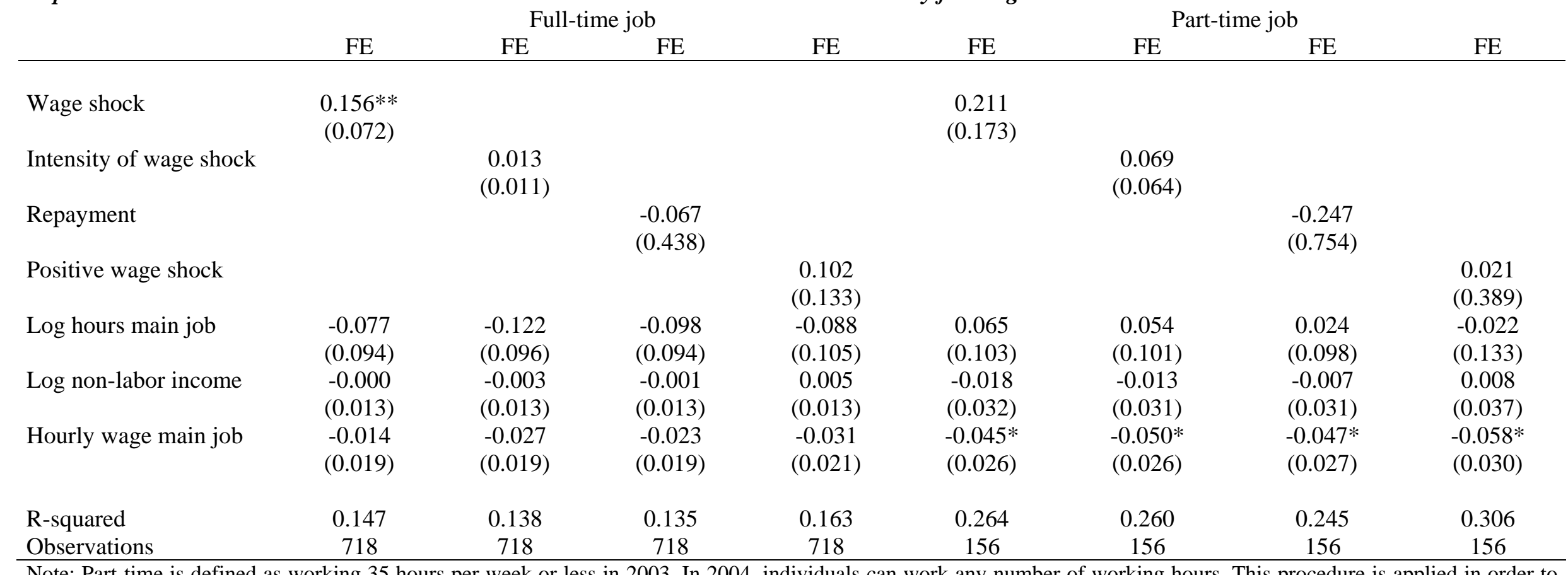

\begin{tabular}{|c|c|c|c|c|c|c|c|c|}
\hline & & & & & & & & \\
\hline & $\mathrm{FE}$ & $\mathrm{FE}$ & $\mathrm{FE}$ & $\mathrm{FE}$ & FE & $\mathrm{FE}$ & $\mathrm{FE}$ & $\mathrm{FE}$ \\
\hline Intensity of wage shock & & $\begin{array}{c}0.013 \\
(0.011)\end{array}$ & & & & $\begin{array}{c}0.069 \\
(0.064)\end{array}$ & & \\
\hline Repayment & & & $\begin{array}{l}-0.067 \\
(0.438)\end{array}$ & & & & $\begin{array}{l}-0.247 \\
(0.754)\end{array}$ & \\
\hline Positive wage shock & & & & $\begin{array}{c}0.102 \\
(0.133)\end{array}$ & & & & $\begin{array}{c}0.021 \\
(0.389)\end{array}$ \\
\hline Log non-labor income & $\begin{array}{l}-0.000 \\
(0.013)\end{array}$ & $\begin{array}{l}-0.003 \\
(0.013)\end{array}$ & $\begin{array}{l}-0.001 \\
(0.013)\end{array}$ & $\begin{array}{c}0.005 \\
(0.013)\end{array}$ & $\begin{array}{l}-0.018 \\
(0.032)\end{array}$ & $\begin{array}{l}-0.013 \\
(0.031)\end{array}$ & $\begin{array}{l}-0.007 \\
(0.031)\end{array}$ & $\begin{array}{c}0.008 \\
(0.037)\end{array}$ \\
\hline Hourly wage main job & $\begin{array}{c}-0.014 \\
(0.019)\end{array}$ & $\begin{array}{l}-0.027 \\
(0.019)\end{array}$ & $\begin{array}{l}-0.023 \\
(0.019)\end{array}$ & $\begin{array}{l}-0.031 \\
(0.021)\end{array}$ & $\begin{array}{l}-0.045^{*} \\
(0.026)\end{array}$ & $\begin{array}{l}-0.050^{*} \\
(0.026)\end{array}$ & $\begin{array}{l}-0.047^{*} \\
(0.027)\end{array}$ & $\begin{array}{l}-0.058^{*} \\
(0.030)\end{array}$ \\
\hline R-squared & 0.147 & 0.138 & 0.135 & 0.163 & 0.264 & 0.260 & 0.245 & 0.306 \\
\hline
\end{tabular}

Part-time job

Note: Part-time is defined as working 35 hours per week or less in 2003. In 2004, individuals can work any number of working hours. This procedure is applied in order to keep the panel balanced and to prevent from a mechanical sample selection. This would be the case if, for instance, full-time employees suffer from a wage shock and reduce their working hours enough to switch from full-time to part-time employment in 2004. Standard errors in parentheses; *** $\mathrm{p}<0.01$, ** $\mathrm{p}<0.05$, * $\mathrm{p}<0.1$. Source: ULMS, own calculations. 
Table A11a: Weighting with attrition probability, pooled OLS and Tobit models
(1)
(2)
(3)
(4)
(5)
(6)

Dependent variable

Second job holding

Hours in second job

\begin{tabular}{|c|c|c|c|c|c|c|}
\hline & OLS & OLS & OLS & Tobit & Tobit & Tobit \\
\hline \multirow[t]{2}{*}{ Wage shock } & $0.023 * *$ & $0.025^{* *}$ & $0.026^{* *}$ & $4.566 * *$ & $4.617 * * *$ & $4.621 * * *$ \\
\hline & $(0.011)$ & $(0.012)$ & $(0.012)$ & $(1.787)$ & $(1.780)$ & $(1.716)$ \\
\hline \multirow{2}{*}{ Log hours main job } & -0.020 & $-0.021^{*}$ & $-0.022^{*}$ & $-3.621 * *$ & $-3.556 * *$ & $-3.247^{*}$ \\
\hline & $(0.012)$ & $(0.013)$ & $(0.013)$ & $(1.789)$ & $(1.731)$ & (1.698) \\
\hline \multirow[t]{2}{*}{ Log non-labor inc } & & & $0.006 * * *$ & & & $2.397^{* * *}$ \\
\hline & & & $(0.001)$ & & & $(0.799)$ \\
\hline \multirow[t]{2}{*}{ Hrly wage main job } & & & 0.000 & & & -0.109 \\
\hline & & & $(0.002)$ & & & $(0.368)$ \\
\hline Second job shadow & & & $0.001^{*}$ & & & $\begin{array}{l}0.148^{*} \\
(0078)\end{array}$ \\
\hline Weights & $\begin{array}{c}\text { Un- } \\
\text { weighted }\end{array}$ & Weighted & Weighted & $\begin{array}{c}\text { Un- } \\
\text { weighted }\end{array}$ & Weighted & $\begin{array}{l}\text { Weighte } \\
\text { d }\end{array}$ \\
\hline Demographic contr. & $\mathrm{X}$ & $\mathrm{X}$ & $\mathrm{X}$ & X & $\mathrm{X}$ & $\mathrm{X}$ \\
\hline Job \& wealth contr. & - & - & $\mathrm{X}$ & - & - & $\mathrm{X}$ \\
\hline LL & 1663 & 1559 & 1574 & -574.1 & -383.9 & -374.1 \\
\hline (Pseudo) R-squared & 0.014 & 0.015 & 0.024 & 0.035 & 0.037 & 0.062 \\
\hline Observations & 3472 & 3472 & 3472 & 3472 & 3472 & 3472 \\
\hline
\end{tabular}

Table A11b: Weighting with attrition probability, pooled OLS and Tobit models
(1)
(2)
(3)
(4)
(5)

(6)

Dependent variable

Subsidiary farming

Hours in subsidiary farming

\begin{tabular}{|c|c|c|c|c|c|c|}
\hline & OLS & OLS & OLS & Tobit & Tobit & Tobit \\
\hline Wage shock & $\begin{array}{c}0.009 \\
(0.046)\end{array}$ & $\begin{array}{c}0.016 \\
(0.045)\end{array}$ & $\begin{array}{c}0.021 \\
(0.047)\end{array}$ & $\begin{array}{c}4.661 * * * \\
(1.161)\end{array}$ & $\begin{array}{c}4.579 * * * \\
(1.359)\end{array}$ & $\begin{array}{c}2.942 * * \\
(1.315)\end{array}$ \\
\hline Log hours main job & 0.003 & -0.009 & 0.001 & $-0.200 * * *$ & $-0.191 * * *$ & - \\
\hline & $(0.045)$ & $(0.041)$ & $(0.043)$ & $(0.035)$ & $(0.041)$ & $\begin{array}{c}0.217 * * * \\
(0.044)\end{array}$ \\
\hline Log non-labor inc & & & $\begin{array}{l}-0.005 \\
(0.009)\end{array}$ & & & $\begin{array}{l}-0.202 \\
(0.253)\end{array}$ \\
\hline Hrly wage main job & & & $\begin{array}{c}0.005 \\
(0.010)\end{array}$ & & & $\begin{array}{l}-0.608 \\
(0.407)\end{array}$ \\
\hline $\begin{array}{l}\text { Second job shadow } \\
\text { wage }\end{array}$ & $\begin{array}{c}0.009 \\
(0.046)\end{array}$ & $\begin{array}{c}0.016 \\
(0.045)\end{array}$ & $\begin{array}{c}0.021 \\
(0.047)\end{array}$ & $\begin{array}{c}4.661^{* * * *} \\
(1.161)\end{array}$ & $\begin{array}{c}4.579 * * * \\
(1.359)\end{array}$ & $\begin{array}{c}2.942 * * \\
(1.315)\end{array}$ \\
\hline Weights & $\begin{array}{c}\text { Un- } \\
\text { weighted }\end{array}$ & Weighted & Weighted & $\begin{array}{c}\text { Un- } \\
\text { weighted }\end{array}$ & Weighted & $\begin{array}{l}\text { Weighte } \\
\text { d }\end{array}$ \\
\hline Demographic contr. & $\mathrm{X}$ & $\mathrm{X}$ & $\mathrm{X}$ & $\mathrm{X}$ & $\mathrm{X}$ & $\mathrm{X}$ \\
\hline Job \& wealth contr. & - & - & $\mathrm{X}$ & - & - & $\mathrm{X}$ \\
\hline LL & -497.5 & -494.4 & -482.3 & -6287 & -3749 & -3732 \\
\hline (Pseudo) R-squared & 0.103 & 0.098 & 0.123 & 0.032 & 0.029 & 0.033 \\
\hline Observations & 3472 & 3472 & 3472 & 3472 & 3472 & 3472 \\
\hline
\end{tabular}


Table A12a: Weighting with attrition probability, panel FE and RE models
(1)
(2)
(3)

(4)

Dependent variable

Second job

Hours in second job

\begin{tabular}{lcccc} 
& FE linear & FE linear & RE Tobit & RE Tobit \\
\hline Wage shock & $0.029^{* *}$ & $0.033^{* *}$ & $4.845^{* *}$ & $4.816^{* *}$ \\
& $(0.013)$ & $(0.013)$ & $(1.905)$ & $(2.217)$ \\
Log hours main job & -0.021 & -0.020 & $-3.927^{* *}$ & $-3.666^{*}$ \\
& $(0.014)$ & $(0.014)$ & $(1.823)$ & $(2.134)$ \\
Log non-labor income & $0.006^{* * *}$ & $0.006^{* *}$ & $2.452^{* * *}$ & $2.422^{* * *}$ \\
& $(0.002)$ & $(0.002)$ & $(0.680)$ & $(0.836)$ \\
Hourly wage main job & 0.002 & 0.002 & -0.068 & -0.129 \\
& $(0.003)$ & $(0.003)$ & $(0.377)$ & $(0.466)$ \\
Second job shadow & -0.000 & -0.000 & $0.165^{*}$ & 0.178 \\
wage & $(0.005)$ & $(0.005)$ & $(0.086)$ & $(0.111)$ \\
Weights & Unweighted & Weighted & Unweighted & Weighted \\
Demographic controls & $\mathrm{X}$ & $\mathrm{X}$ & $\mathrm{X}$ & $\mathrm{X}$ \\
Job \& wealth controls & $\mathrm{X}$ & $\mathrm{X}$ & $\mathrm{X}$ & $\mathrm{X}$ \\
Rho & 0.530 & 0.519 & 0.713 & 0.684 \\
LL & 3630.9 & 3541.9 & -532.0 & -357.9 \\
R-squared / Chi2 & 0.016 & 0.018 & 35.1 & 23.3 \\
Observations & 3472 & 3472 & 3472 & 3472 \\
\hline Not: Weighs
\end{tabular}

Note: Weights are inverse probability weights. Standard errors in parentheses; ${ }^{* * *} \mathrm{p}<0.01,{ }^{* *} \mathrm{p}<0.05,{ }^{*}$ $\mathrm{p}<0.1$. Source: ULMS, own calculations.

Table A12b: Weighting with attrition probability, panel FE and RE models
(1)
(2)
(3)

(4)

Dependent variable

Subsidiary farming

Hours in subsidiary farming

\begin{tabular}{lcccc} 
& FE linear & FE linear & RE Tobit & RE Tobit \\
\hline Wage shock & $0.132^{* *}$ & $0.127^{* *}$ & $2.293^{* *}$ & $3.111^{* *}$ \\
& $(0.064)$ & $(0.063)$ & $(1.112)$ & $(1.603)$ \\
Log hours main job & 0.006 & 0.000 & $-0.240^{* * *}$ & $-0.218^{* * *}$ \\
& $(0.060)$ & $(0.055)$ & $(0.047)$ & $(0.049)$ \\
Log non-labor income & -0.001 & -0.004 & -0.043 & -0.249 \\
& $(0.012)$ & $(0.011)$ & $(0.246)$ & $(0.316)$ \\
Hourly wage main job & -0.020 & -0.016 & -0.587 & -0.593 \\
& $(0.014)$ & $(0.013)$ & $(0.396)$ & $(0.376)$ \\
Weights & Unweighted & Weighted & Unweighted & Weighted \\
Demographic controls & $\mathrm{X}$ & $\mathrm{X}$ & $\mathrm{X}$ & $\mathrm{X}$ \\
Job \& wealth controls & $\mathrm{X}$ & $\mathrm{X}$ & $\mathrm{X}$ & $\mathrm{X}$ \\
Rho & 0.635 & 0.632 & 0.374 & 0.389 \\
LL & 135.7 & 139.0 & -6224 & -3677 \\
R-squared / Chi2 & 0.0337 & 0.0555 & 312.1 & 208.3 \\
Observations & 874 & 874 & 1834 & 1834 \\
\hline Note: Weights are inverse probability weights. Standard errors in parentheses; ${ }^{* * *} \mathrm{p}<0.01, * *$ & $\mathrm{p}<0.05, *$ \\
p<0.1. Source: ULMS, own calculations. & & &
\end{tabular}




\section{Appendix B: Attrition Analysis}

One potential source of bias in the ULMS stems from potential non-random panel attrition. Sample attrition of the ULMS amounts to 19.5 percent for the entire sample and 18.6 percent among those employed in 2003. For the purpose of this study it is, however, interesting to analyze exits more broadly and to consider not only individuals who leave the survey but also those who leave the employee status. A more general analysis indicates that a substantial fraction of workers leave the employed sample in the second year of the panel. As the goal is to track the causal effect from labor market shocks on labor supply, it is important to investigate, in which labor market states workers moved, and whether they potentially left jobs as a response to wage uncertainty. From 2003 to 2004, the raw exit rate from dependent employment is at 31 percent of the 2003 sample of dependently employed, while 19 percent newly entered into this employment status. The substantial share of exits accounts for persons who have reached pension age, engaged in entrepreneurial or professional farming business, left their job temporarily in the reference week (e.g. for sickness reasons, holidays or maternity leave) or left the labor force voluntarily (all together 9.3 percent) or became unemployed (3.1 percent). The remaining 18.6 percent attrited from the survey. Table B1 sheds light on the hypotheses that wage arrears might be correlated with different kinds of exit behavior from dependent employment. Therefore simple binary indicators are constructed which take on the value of one if an employed ULMS respondent of 2003 left the sample for any of the given reasons, and zero otherwise. These dummies are regressed on a wage shock indicator and some demographic and regional characteristics employing a simple linear probability regression framework. If attrition was perfectly random, we expect no statistically significant association between the propensity to leave the sample and any right-hand side variables. This is rather unlikely and indeed, we find that the demographics carry the expected signs. Women and older respondents are less likely to leave the survey, while education matters for unemployment. The results also suggest some specific geographic patterns of panel attrition with inhabitants of the Centre and East region being more reluctant to drop out of the panel. Most importantly, however, there is no significant positive or negative correlation between the incidence of a wage shock in 2003 and subsequent exit from employment or the survey.

Two approaches are used in order to investigate the impact of sample attrition on the estimated second job holding responses: First, beside results stemming from a 
balanced panel, the robustness of the results is shown with a maximal data sample (Table A4 and Table A5). Second, the main results are re-estimated using inverse probability weights (Wooldridge, 2002) that account for the predominant attrition of specific subgroups (Table A11 and Table A12). ${ }^{36}$ Both procedures have very little impact on the estimation results and confirm the robustness of the findings. Table B1: Determinants of sample attrition, exit from the workforce and
unemployment
(1)
(2)
(3)
(4)

\begin{tabular}{lcccc} 
Dependent variable: & $\begin{array}{c}\text { Sample attrition } \\
\text { in } \mathbf{+ 1}\end{array}$ & $\begin{array}{c}\text { Survey } \\
\text { attrition } \\
\text { in } \mathbf{+}+\mathbf{1}\end{array}$ & $\begin{array}{c}\text { Unemploy- } \\
\text { ment } \\
\text { in } \mathbf{+ 1}\end{array}$ & $\begin{array}{c}\text { Other exits } \\
\text { from } \\
\text { employment } \\
\text { in } \mathbf{+ 1}\end{array}$ \\
\hline Wage arrear in $t$ & 0.006 & -0.027 & 0.008 & 0.015 \\
Age & $(0.027)$ & $(0.021)$ & $(0.010)$ & $(0.014)$ \\
& -0.001 & $-0.002^{* * *}$ & -0.000 & $0.001^{* *}$ \\
Years of education & $(0.001)$ & $(0.001)$ & $(0.000)$ & $(0.000)$ \\
Female & $-0.008^{* *}$ & 0.000 & $-0.003^{* *}$ & -0.003 \\
& $(0.004)$ & $(0.003)$ & $(0.001)$ & $(0.002)$ \\
Married & -0.017 & $-0.038^{* *}$ & 0.009 & $0.022^{* *}$ \\
& $(0.018)$ & $(0.015)$ & $(0.006)$ & $(0.009)$ \\
Pseudo R-squared & $0.033^{*}$ & 0.022 & 0.002 & 0.001 \\
Observations & $(0.019)$ & $(0.015)$ & $(0.006)$ & $(0.011)$ \\
Fraction of 2003 sample & 0.062 & 0.132 & 0.049 & 0.030 \\
\hline
\end{tabular}

Note: The sample consists of all individuals who were eligible for re-interview in 2004. The estimation adopts a forward looking linear probability model. Cases (2), (3) and (4) are sub items of (1). All regressions control for regions. Standard errors in parentheses; ${ }^{* * *} \mathrm{p}<0.01,{ }^{* *} \mathrm{p}<0.05,{ }^{*} \mathrm{p}<0.1$. Source: ULMS, own calculations.

\footnotetext{
${ }^{36}$ Inverse probability weighting proceeds in two steps, where in the first step an attrition indicator for $t+1$ is regressed on the covariates at $t$. In the second step, the fitted attrition probabilities are used as inverse weights.
} 